JULIO CESAR CARRANZA MARTINEZ

\title{
NADH DESIDROGENASE MITOCONDRIAL DE Trypanosoma cruzi: SUBUNIDADE 7 PARA DIAGNÓSTICO DIFERENCIAL DE ISOLADOS HUMANOS E ANÁLISE FUNCIONAL
}

\begin{abstract}
Tese apresentada ao Instituto de Ciências Biomédicas da Universidade de São Paulo, para obtenção do Título de Doutor em Ciências.
\end{abstract}

São Paulo 
JULIO CESAR CARRANZA MARTINEZ

\section{NADH DESIDROGENASE MITOCONDRIAL DE Trypanosoma cruzi: SUBUNIDADE 7 PARA DIAGNÓSTICO DIFERENCIAL DE ISOLADOS HUMANOS E ANÁLISE FUNCIONAL}

Tese apresentada ao Instituto de Ciências Biomédicas da Universidade de São Paulo, para obtenção do Título de Doutor em Ciências.

Área de concentração:

Biologia da Relação Patógeno-Hospedeiro

Orientador(a): Profa. Dra. Bianca S. Zingales 
DADOS DE CATALOGAÇÃO NA PUBLICAÇÃO (CIP)

Serviço de Biblioteca e Informação Biomédica do

Instituto de Ciências Biomédicas da Universidade de São Paulo

C reprodução total

Carranza Martinez, Julio Cesar.

NADH desidrogenase mitocondrial de Trypanosoma cruzi: subunidade 7 para diagnóstico diferencial de isolados humanos e análise funcional / Julio Cesar Carranza Martinez. -- São Paulo, 2008.

Orientador: Bianca Silvana Zingales.

Tese (Doutorado) - Universidade de São Paulo. Instituto de Ciências Biomédicas. Departamento de Parasitologia. Área de concentração: Biologia da Relação Patógeno-Hospedeiro. Linha de pesquisa: Biologia Molecular de Trypanosoma cruzi.

Versão do título para o inglês: Mitochondrial NADH dehydrogenase of Trypanosoma cruzi: subunit 7 for differential diagnosis of human isolates and functional analysis.

Descritores: 1 . Trypanosoma cruzi 2 2. Mitocôndria 3 3. Doença de Chagas 4. Genes de maxicírculo 5. Peróxido de hidrogênio 6.

Doenças parasitárias I. Zingales, Bianca Silva II. Universidade de São Paulo. Instituto de Ciências Biomédicas. Programa de Pós-Graduação em Biologia da Relação Patógeno-Hospedeiro. III. Título. 


\section{UNIVERSIDADE DE SÃO PAULO \\ INSTITUTO DE CIÊNCIAS BIOMÉDICAS}

$\begin{array}{ll}\text { Candidato(a): } & \text { Julio Cesar Carranza Martinez } \\ \text { Titulo da Tese: } & \text { NADH desidrogenase mitocondrial de Trypanosoma cruzi: } \\ & \text { subunidade } 7 \text { para diagnóstico diferencial de isolados } \\ & \text { humanos e análise funcional. }\end{array}$

Orientador(a): $\quad$ Profa. Dra. Bianca Silvana Zingales

A Comissão Julgadora dos trabalhos de Defesa da Tese de Doutorado, em sessão pública realizada a .................., considerou

\section{( ) Aprovado(a) ( ) Reprovado(a)}

Examinador(a): Assinatura:

Nome:

Instituição:

Examinador(a): Assinatura:

Nome:

Instituição:

Examinador(a): Assinatura:

Nome:

Instituição:

Examinador(a): Assinatura:

Nome:

Instituição:

Presidente: Assinatura:

Nome: 
UNIVERSIDADE DE SÃO PAULO

INSTITUTO DE CIÊNCIAS BIOMÉDICAS

Av. Prof. Lineu Prestes, 2415 - CEP. 05508-000 Săo Paulo, SP - Brasil

Telefone :(55) (11) 3091-7733 - telefax : (55) (11) 3091-7438

e-mail: $\operatorname{cep} a$ ich. usp. b

\section{CERTIFICADO DE ISENÇÃO}

Certificamos que o Protocolo CEP-ICB N ${ }^{\circ} \mathbf{1 3 9}$, referente ao projeto intitulado "Gene da subunidade 7 da $\mathrm{NADH}$ desidrogenase mitocondrial para o diagnóstico diferencial de cepas de trypanosoma cruzi de pacientes assintomáticos e com cardiopatia chagásica " sob a responsabilidade de Júlio César Carranza Martinez, foi analisado na

presente data pela CEEA - COMISSÃO DE ÉTICA EM EXPERIMENTAC̄̃̃O ANimal e pela CEPSH - COMISSÃo de ÉTICA EM PESQUiSA COM SERES HUMANOS, tendo sido deliberado que o referido projeto não envolve manipulação animal ou humana que justifique uma aprovação quanto aos princípios éticos exigidos por ambas as Comissões.

São Paulo, 23 de fevereiro de 2006.
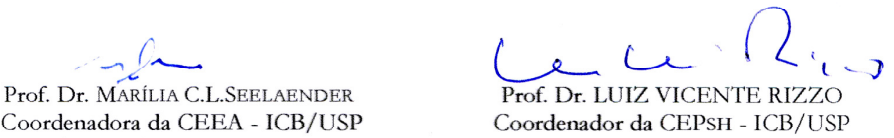
A minha filha Laura, com muito amor e admiração, pela sua paciência nestes longos anos de ausência.

Dedico 


\section{AGRADECIMENTOS}

À Profa. Dra. Bianca Zingales, pelas oportunidades recebidas nesta importante etapa acadêmica, pela excelente orientação e pelos muitos ensinamentos.

A Marcelo Nunes Silva pela amizade e companheirismo, além de sua ajuda e apoio profissional e técnico que viabilizou a execução dos experimentos.

À Profa. Dra. Alícia J. Kowaltowski, pelas grandes contribuições neste trabalho, fundamentais para essa tese.

Aos professores Drs. E. Chiari, L. M. Galvão e E. Gontijo da Universidade Federal de Minas Gerais, pela colaboração na obtenção de isolados humanos de T. cruzi, indispensáveis para o desenvolvimento deste trabalho.

Ao Prof. Dr. Hugo Armelin, pela utilização de equipamentos de seu laboratório.

Ao Prof. Dr. Gerhard Wunderlich por seu apoio para a realização de experimentos de PCR em tempo real.

À Susan lenne, pela competência e presteza, além do auxílio, dicas e informações durante a confecção da tese.

Aos meus companheiros de laboratório Camila, Aurélio e Margoth pelo seu apoio na execução deste trabalho.

Aos professores do Departamento de Parasitologia (Curso de pós-graduação em Biologia da Relação Patógeno-Hospedeiro) do Instituto de Ciências Biomédicas.

Às funcionárias Wilma e Ângela da seção de pós-graduação, Departamento de Parasitologia, pela atenção e dedicação. 
Ao Instituto Colombiano para el Desarrollo de la Ciencia y Tecnología "Francisco José de Caldas" (COLCIENCIAS), LASPAU (Academic and Professional Programs for the Americas), pelo apoio financeiro.

À Universidad del Tolima. Ibagué (Tolima - Colombia). Pelo apoio institucional e financeiro. 


\section{RESUMO}

CARRANZA MARTINEZ, J.C. NADH desidrogenase mitocondrial de Trypanosoma cruzi: subunidade 7 para diagnóstico diferencial de isolados humanos e análise funcional. 2008. 174 f. Tese (Doutorado) - Instituto de Ciências Biomédicas, Universidade de São Paulo, São Paulo, 2008.

A doença de Chagas, causada pelo protozoário Trypanosoma cruzi, apresenta um espectro de manifestações clínicas que variam entre indivíduos e regiões geográficas. Na fase crônica, cerca de $70 \%$ dos indivíduos são assintomáticos (ASS), ao passo que $\sim 30 \%$ desenvolvem a forma cardíaca (CCC) ou digestiva. Dados obtidos com microarranjos de DNA, indicavam a transcrição diferencial do gene que codifica a subunidade 7 (ND7) da NADH desidrogenase mitocondrial (complexo I) em isolados de pacientes com CCC em relação a isolados de ASS. Esta observação sugeria que o gene ND7 poderia ser um alvo para diferenciar as duas classes de isolados. Neste trabalho, analisamos a estrutura de ND7 por ensaios de PCR e verificamos um dimorfismo: amplicon de $900 \mathrm{pb}$ para isolados de pacientes com CCC e de 500 pb para ASS. O seqüenciamento dos produtos de PCR revelou uma deleção de $455 \mathrm{pb}$ na região central do gene, que era conservada entre os isolados de ASS. Verificamos que esta deleção é encontrada em algumas cepas do grupo $T$. cruzi ll (sub-grupo llb), e concluímos que este seria um evento antigo, e que os isolados com a mutação descendem de um ancestral comum. Também observamos dimorfismo na estrutura do gene ND4, que codifica outra subunidade do complexo I, e conservação da estrutura do gene COIII, que codifica a subunidade III da citocromo oxidase. Analisamos a estrutura de ND7 em isolados de 75 pacientes com forma clínica caracterizada. No grupo CCC, o produto de $900 \mathrm{pb}$ foi observado em $42 \%$ das amostras e o de $500 \mathrm{pb}$, em $58 \%$. No grupo ASS, o produto de $900 \mathrm{pb}$ foi obtido em $44,6 \%$ dos isolados, o de $500 \mathrm{pb}$ em $46,4 \%$, e ambos os produtos em $8,9 \%$. Estes dados indicam não haver uma correlação entre o tamanho do amplicon de ND7 e as formas indeterminada ou cardíaca da doença de Chagas. Uma vez que a funcionalidade do complexo I em tripanossomatídeos é debatida e que os isolados com deleções em ND4 e ND7 representam mutantes naturais para este complexo, investigamos alguns parâmetros do funcionamento da mitocôndria em cepas 
controle e portadoras de mutações. Verificamos que as deleções nos genes não afetam a velocidade de consumo de oxigênio em formas epimastigotas permeabilizadas com digitonina. Concluímos que o complexo I não é funcional ou é pouco funcional neste estágio. Evidências indiretas sugeriram que parte do NADH formado na mitocôndria seria oxidado via fumarato redutase. Observamos que os níveis de produção de peróxido de hidrogênio pela mitocôndria não guardam relação com a presença das deleções nos dois genes. As diferenças nos níveis de $\mathrm{H}_{2} \mathrm{O}_{2}$ observados parecem ser cepa-específicos. Analisamos ainda a sensibilidade a $\mathrm{H}_{2} \mathrm{O}_{2}$ em isolados de pacientes. Observamos variação nos valores de $\mathrm{Cl}_{50}$ entre as cepas, mas que não se correlacionam com as formas clínicas da doença. Finalmente, analisamos a abundância de transcritos dos genes que codificam duas isoformas de superóxido dismutase-A; triparedoxina peroxidase e tripanotiona sintetase nos isolados. Observamos maior abundância de transcritos nas cepas mais sensíveis a $\mathrm{H}_{2} \mathrm{O}_{2}$ apenas para o gene da tripanotiona sintetase.

Palavras-chave: Trypanosoma cruzi. Doença de Chagas. Genes do maxicírculo. Diagnóstico. Complexo I mitocondrial. 


\section{ABSTRACT}

CARRANZA MARTINEZ, J.C. Mitochondrial NADH dehydrogenase of Trypanosoma cruzi: subunit 7 for differential diagnosis of human isolates and functional analysis 2008. $174 \mathrm{f}$. Thesis $(\mathrm{PhD})$ - Institute of Biomedical Sciences, University of São Paulo, São Paulo, 2008.

Chagas disease, caused by the protozoan Trypanosoma cruzi, presents a wide spectrum of clinical manifestations varying between individuals and geographical regions. In the chronic phase, around $70 \%$ of the individuals are asymptomatic (ASY), whereas $\sim 30 \%$ develop the cardiac (CCC) or digestive forms of the disease. Data obtained with DNA microarrays indicated the differential transcription of the mitochondrial gene NADH dehydrogenase (complex I) subunit 7 (ND7) in T. cruzi isolates from CCC patients as compared to isolates of ASY patients. This observation suggested that the ND7 gene could be a potential target to differentiate the two classes of strains. In this study, we analyzed the ND7 structure by PCR assays and observed a sequence dimorphism: 900-bp amplicon in isolates from CCC patients and 500-bp amplicon in ASY isolates. Sequencing of PCR products revealed a 455bp deletion in the central region of the gene, which is conserved among ASY isolates. We verified that this deletion is found in some strains of T.cruzi II group (sub-group $\mathrm{llb}$ ), and concluded that this is probably an ancient event, and that the isolates with the deletion descend from a common ancestor wherein this mutation arose. Among the isolates, we also observed dimorphism in the structure of ND4 gene, coding for another subunit of complex I; and conservation of the structure of COIII gene, coding for cytochrome oxidase subunit III. The structure of ND7 was analyzed in the isolates of 75 patients with well-characterized clinical forms of the disease. In group CCC, $42 \%$ of the isolates exhibited a 900 -bp product, whereas $58 \%$ displayed a $500-b p$ product. In group ASY, the 900 -bp product was obtained in $44.6 \%$ of the isolates, the 500 -bp in $46.4 \%$, and both products in $8.9 \%$. These data indicate that there is no correlation between the size of the ND7 amplicon and the asymptomatic or cardiac forms of Chagas disease. Since the function of complex I in trypanosomatids is still debatable, and isolates with ND4 and ND7 deletions represent natural mutants of this complex, we investigated some mitochondrial functional parameters in control and 
mutant strains. We observed that deletions in either gene do not affect the oxygen consumption in epimastigote forms permeabilized with digitonin. We concluded that complex I is non-functional or has little function in this stage of the parasite. Indirect evidence suggests that a considerable fraction of the $\mathrm{NADH}$ formed in the mitochondria is oxidized via fumarate reductase. We observed no correlation between mitochondrial production of hydrogen peroxide and the deletions in ND4 and ND7 genes. The differences observed in $\mathrm{H}_{2} \mathrm{O}_{2}$ levels appear to be strain-specific. In addition, we analyzed the sensibility of isolates to $\mathrm{H}_{2} \mathrm{O}_{2}$. The variation of the $\mathrm{IC}_{50}$ values among the strains was evaluated, revealing no correlation with the clinical forms of the disease. Finally, in the isolates the abundance of gene transcripts of two isoforms of superoxide dismutase-A, tryparedoxin peroxidase and trypanothione synthetase was analyzed. Only for the trypanothione synthetase gene a higher abundance of transcripts in strains more sensitive to $\mathrm{H}_{2} \mathrm{O}_{2}$ was observed.

Keywords: Trypanosoma cruzi. Chagas disease. Maxicircle genes. Diagnosis. Mitochondrial complex I. 


\section{LISTA DE FIGURAS}

Figura 1. Visão geral do metabolismo intermediário de tripanossomatídeos. $\quad 29$

Figura 2. Visão geral das reações metabólicas que ocorrem no glicossomo. 32

Figura 3. Visão geral das reações metabólicas que ocorrem na mitocôndria. $\quad 39$

Figura 4. Via da Tripanotiona para detoxificação de $\mathrm{H}_{2} \mathrm{O}_{2}$ em

tripanossomatídeos. 42

Figura 5. Esquema da cadeia de transporte de elétrons e ATP sintase localizadas na membrana interna da mitocôndria. $\quad 44$

Figura 6. Representação esquemática do complexo I de T. brucei. 46

Figura 7. Diagrama do maxicírculo de T. cruzi. 49

Figura 8. Produtos de amplificação do gene ND7 em isolados de pacientes com CCC e ASS.

Figura 9. Alinhamento das seqüencias de ND7 das cepas Esmeraldo,

CL Brener, 115, Silvio X10, VL10 e Y.

Figura 10. Representação esquemática da região que contém os genes MURF5, ND7 e COIII no maxicírculo de T. cruzi e localização da deleção no gene ND7.

Figura 11. Distribuição de gênero, apresentação clínica e faixa etária dos pacientes.

Figura 12. Distribuição do tamanho do amplicon de ND7 em pacientes ASS e com CCC.

Figura 13. Produtos de amplificação de ND7 em isolados de T. cruzi.

Figura 14. Alinhamento das seqüências do produto de amplificação de $\sim 900$ $\mathrm{pb}$ de dois isolados humanos com as seqüências de ND7 das cepas Esmeraldo e CL Brener.

Figura 15. Alinhamento das seqüências do produto de amplificação de 500 pb de isolados humanos com a seqüência da cepa VL 10.

Figura 16. Produtos de amplificação do gene COIII.

Figura 17. Produtos de amplificação do gene ND4. Análise em gel de agarose $0,8 \%$ corado com brometo de etidio.

Figura 18. Porcentagem de viabilidade de formas epimastigotas de

CL Brener mantidas em tampão de respiração. 
Figura 19. Determinação do controle de respiração em epimastigotas de CL Brener permeabilizados com digitonina.

Figura 20. Esquema do traçado do consumo de oxigênio em função da adição de reagentes.

Figura 21. Traçado de fluorescência para determinação do nível de NAD mitocondrial.

Figura 22. Diferenças na abundância de NAD mitocondrial nas cepas $115 \mathrm{e}$ CL Brener.

Figura 23. Distribuição das cepas de T. cruzi em duas categorias de acordo com sua sensibilidade a $\mathrm{H}_{2} \mathrm{O}_{2}$.

Figura 24. Abundância relativa de transcritos de quatro genes em cepas de T. cruzi.

Figura 25. Comparação das médias da abundância relativa de transcritos de quatro genes nos dois grupos de cepas de $T$. cruzi. 


\section{LISTA DE TABELAS}

Tabela 1. Seqüência dos oligonucleotídeos utilizados nos experimentos de PCR em tempo real.

Tabela 2. Características de cepas de T. cruzi e tamanho do amplicon do gene ND7.

Tabela 3. Reações amplificação de ND7 variando-se a concentração de

DNA molde.

Tabela 4. Estrutura dos genes ND7, ND4 e COIIl em isolados humanos.

Análise por PCR.

Tabela 5. Velocidade de consumo de oxigênio e CR com substratos de complexo I em isolados de T. cruzi.

Tabela 6. Velocidade de consumo de oxigênio e CR com substrato de complexo II em isolados de T. cruzi.

Tabela 7. Velocidade de consumo de oxigênio e CR com substrato de complexo I com e sem adição de malonato em isolados de T. cruzi.

Tabela 8. Velocidade de consumo de oxigênio e CR com substrato de complexo II com e sem adição de malonato em isolados de T. cruzi.

Tabela 9. Produção de $\mathrm{H}_{2} \mathrm{O}_{2}$ mitocondrial (valores em pmoles. $\mathrm{min}^{-1} \cdot \mathrm{mg}^{-1}$ ).

Tabela 10. Diferenças na abundância relativa de NAD mitocondrial nas cepas 115 e CL Brener.

Tabela 11. Sensibilidade de isolados de T. cruzi a peróxido de hidrogênio. Valores de $\mathrm{Cl}_{50}$

Tabela 12. Razão de hibridização dos cDNA das cepas VL10 e 115 e da abundância de transcritos.

Tabela 13. Abundância relativa de transcritos de quatro genes. 


\section{SUMÁRIO}

1 INTRODUÇÃO 20

1.1 ASPECTOS GERAIS DA TRIPANOSSOMÍASE AMERICANA 20

$\begin{array}{ll}\text { 1.1.1 O parasita } & 20\end{array}$

1.1.2 A doença de Chagas 21

1.1.3 Variabilidade genética das populações de T. cruzi 24

1.2 ALGUMAS CARACTERÍSTICAS DO METABOLISMO DE T. cruzi 27

1.2.1 Visão geral do Metabolismo intermediário 27

1.2.2 Transporte e utilização de carboidratos, proteínas e aminoácidos $\quad 30$

1.2.3 Vias de fermentação succínica e balanço redóx 31

1.2.4 Via das Pentoses Fosfato (PPP) 33

1.2.5 Metabolismo de proteínas e aminoácidos 34

1.2.6 Geração de ATP 37

1.2.7 Geração de Espécies Reativas de Oxigênio (EROs) e mecanismos $\begin{array}{ll}\text { de defesa } & 40\end{array}$

1.3 A MITOCÔNDRIA: ESTRUTURA E FUNÇÃO 42

1.4 GENOMA MITOCONDRIAL EM TRIPANOSSOMATÍDEOS 48

1.5 CONTROLE DA EXPRESSÃO GÊNICA EM TRIPANOSSOMATÍDEOS 50

2 JUSTIFICATIVA 52

3 OBJETIVOS 53

4 MATERIAL E MÉTODOS 54

4.1 CEPAS E ISOLADOS DE T. cruzi 54

4.2 GENOTIPAGEM DAS CEPAS 54

4.3 EXTRAÇÃO E PURIFICAÇÃO DE DNA 54

4.4 AMPLIFICAÇÃO DE SEQÜÊNCIAS DE GENES DE MAXICÍRCULOS 55

4.4.1 Subunidade 7 da NADH desidrogenase (ND7) 55

4.4.2 Subunidade III da citocromo oxidase (CollI) 55

4.4.3 Subunidade 4 da NADH desidrogenase mitocondrial (ND4) 56

4.5 CLONAGEM E SEQÜENCIAMENTO DE PRODUTOS DE

4.6 DETERMINAÇÃO DE PARÂMETROS FUNCIONAIS DA MITOCÔNDRIA 
4.6.1 Cultura e obtenção de parasitas

4.6.2 Determinação da viabilidade dos parasitas no meio de reação

4.6.3 Determinação da concentração de digitonina para a permeabilização dos parasitas

4.6.4 Determinação do controle respiratório

4.6.5 Determinação do controle respiratório com piruvato e malato como substratos para o complexo I

4.6.6 Determinação do controle respiratório com succinato como substrato para o complexo II

4.6.7 Avaliação da capacidade da cadeia respiratória mitocondrial de epimastigotas para oxidar NADH via complexo I, bloqueando o complexo II com malonato

4.7 MEDIDA DO PERÓXIDO DE HIDROGÊNIO $\left(\mathrm{H}_{2} \mathrm{O}_{2}\right)$ LIBERADO PELA MITOCÔNDRIA

4.8 MONITORAMENTO DOS NÍVEIS DE NAD MITOCONDRIAL EM EPIMASTIGOTAS

4.9 SENSIBILIDADE DE EPIMASTIGOTAS A PERÓXIDO DE HIDROGÊNIO EXÓGENO

4.10 AVALIAÇÃO DOS NÍVEIS DE mRNA DE GENES ENVOLVIDOS NO MECANISMO DE DETOXIFICAÇÃO DE EROS EM ISOLADOS

HUMANOS POR RT-PCR EM TEMPO REAL

4.10.1 Extração de RNA

4.10.2 Transcrição reversa

4.10.3 PCR em tempo real

4.10.4 Análise dos dados

5 RESULTADOS

5.1 ESTRUTURA DO GENE ND7 65

5.2 SEQÜENCIAMENTO DE ND7 66

5.3 VALIDAÇÃO DA REAÇÃO DIAGNÓSTICA DE PCR PARA ND7 EM ISOLADOS HUMANOS 
5.3.2 Manifestação clínica da doença de Chagas e produto de amplificação de $N D 7$

5.3.3 Análise da estrutura de ND7 em isolados com dois amplicons

5.3.4 Seqüenciamento do produto de amplificação de ND7 de isolados humanos

5.4 ESTRUTURA DO GENE DA SUBUNIDADE III DA CITOCROMO

OXIDASE (COIII) E SUBUNIDADE 4 DA NADH DESIDROGENASE (ND4)

5.5 DETERMINAÇÃO DE PARÂMETROS FUNCIONAIS DA

MITOCÔNDRIA

5.5.1 Estudo da função de complexos I e II da respiração mitocondrial

5.5.2 Determinação da viabilidade dos parasitas no tampão de respiração

5.5.3 Determinação da concentração de digitonina para permeabilização da membrana plasmática

5.5.4 Determinação do controle respiratório

5.5.5 Determinação do CR com substratos do complexo I 80

5.5.6 Determinação do CR com substrato do complexo II 80

5.5.7 Atividade da cadeia respiratória em presença de malonato

5.6 MEDIDA DO PERÓXIDO DE HIDROGÊNIO $\left(\mathrm{H}_{2} \mathrm{O}_{2}\right)$ GERADO NA MITOCÔNDRIA

5.7 MONITORAMENTO DOS NÍVEIS DE NAD MITOCONDRIAL EM EPIMASTIGOTAS

5.8 SENSIBILIDADE DE ISOLADOS HUMANOS A PERÓXIDO

DE HIDROGÊNIO

5.9 NÍVEIS DE TRANSCRITOS DE GENES PUTATIVAMENTE

ENVOLVIDOS NA DETOXIFICAÇÃO DE EROs

6 DISCUSSÃo

6.1 ESTRUTURA DO GENE ND7 
6.3 VALIDAÇÃO DA REAÇÃO DIAGNÓSTICA DE PCR PARA ND7EM ISOLADOS HUMANOS

6.4 FUNCIONALIDADE DO COMPLEXO I MITOCONDRIAL

100

6.5 MEDIDA DO PERÓXIDO DE HIDROGÊNIO $\left(\mathrm{H}_{2} \mathrm{O}_{2}\right)$ LIBERADO PELA MITOCÔNDRIA

6.6 MONITORAMENTO DOS NÍVEIS DE NAD MITOCONDRIAL

105

6.7 SENSIBILIDADE DE ISOLADOS HUMANOS A PERÓXIDO DE HIDROGENNIO

6.8 AVALIAÇÃO DOS NÍVEIS DE mRNA DE GENES PUTATIVAMENTE ENVOLVIDOS NA DETOXIFICAÇÃO DE EROS

7 CONCLUSÕES

7.1 ESTRUTURA DOS GENES DO MAXICÍRCULO ND7, ND4 E COIII 109

7.2 GENOTIPAGEM DE ISOLADOS HUMANOS 109

7.3 PARÂMETROS DO FUNCIONAMENTO DA MITOCÔNDRIA

7.4 SENSIBILIDADE DE ISOLADOS A PERÓXIDO DE HIDROGÊNIO

ANEXOS

ANEXO A ARTIGO EM FASE DE ELABORAÇÃO 


\section{INTRODUÇÃO}

A tripanossomíase americana ou doença de Chagas, descoberta pelo médico brasileiro Carlos Chagas em 1909, é causada pelo protozoário Trypanosoma cruzi. A infecção humana prevalece em 21 países da América Latina, desde o México até Argentina e Chile (World Health Organization (WHO), 2002; Organização Pan Americana da Saúde (OPS), 2006), sendo uma das maiores causas de doença cardíaca e morte relacionada com desordens cardiovasculares em áreas endêmicas.

\subsection{ASPECTOS GERAIS DA TRIPANOSSOMÍASE AMERICANA}

\subsubsection{O parasita}

T. cruzi é transmitido por mais de 130 espécies de insetos da ordem Hemiptera, família Reduviidae, subfamília Triatominae (BARRET et al., 2003). Cinco espécies têm especial importância epidemiológica: Triatoma infestans, $T$. brasiliensis, T. dimidiata, Rhodnius prolixus e Panstrongylus megistus. Além do hospedeiro humano, um grande espectro de mamíferos pode ser infectado e atuar como reservatório do parasita (WHO, 2002). A transmissão vetorial ocorre em moradias pobres em áreas rurais onde várias espécies de triatomíneos vivem nos tetos e paredes rústicas. Nos últimos tempos, foram feitos avanços significativos no controle da transmissão vetorial nos países do Cone Sul da América do Sul com a eliminação do principal vetor domiciliário $T$. infestans. Este fato estimulou os países do grupo Andino e da América Central a iniciar campanhas para a erradicação de outro vetor domiciliar, $R$. prolixus, obtendo-se um sucesso significativo (MONCAYO e ORTIZ, 2006).

Outras vias de transmissão do $T$. cruzi incluem a transfusional, transmissão congênita, transmissão oral por ingestão de alimentos contaminados, transplante de órgãos infectados e acidentes laboratoriais (WHO, 2002).

O ciclo de vida de $T$. cruzi alterna-se entre mamíferos e insetos vetores com diferentes estágios de desenvolvimento em cada hospedeiro. Na região mediana do 
intestino de insetos triatomíneos encontram-se as formas replicativas denominadas epimastigotas. Estas se diferenciam para formas não replicativas, os tripomastigotas metacíclicos, encontrados na parte posterior do intestino e que são eliminados junto com a urina e fezes no momento em que o vetor pica o hospedeiro mamífero. Os tripomastigotas metacíclicos penetram em vários tipos de células e transformam-se em amastigotas que se reproduzem por fissão binária no citoplasma. Os amastigotas se diferenciam em tripomastigotas que, após ruptura celular, vão para a corrente sangüínea e invadem novas células. Quando os tripomastigotas sangüíneos são ingeridos por um inseto triatomíneo, transformam-se em epimastigotas e fecha-se o ciclo. No citoplasma da célula hospedeira foram descritas formas replicativas intermediárias, denominadas epimastigotas-símile (SILBER et al., 2005).

\subsubsection{A doença de Chagas}

A infecção de $T$. cruzi tem uma apresentação clínica variável em humanos. A fase aguda inicial é caracterizada pela parasitemia patente e pode durar entre $30 \mathrm{e}$ 40 dias com sintomas claros ou leves e atípicos. Conseqüentemente, nestes casos, a infecção pode passar despercebida. Em crianças, têm sido observadas complicações neurológicas severas (WHO, 2002). É interessante ressaltar que durante a fase aguda, $T$. cruzi conduz a um estado de imuno-comprometimento que envolve as células do timo e uma intensa ativação policlonal de linfócitos (REINASAN MARTIN et al., 2000).

Depois da fase aguda, os pacientes entram na forma indeterminada da fase crônica que pode durar vários anos ou persistir indefinidamente. Esta fase é caracterizada pela ausência de sintomas clínicos importantes com baixa ou nenhuma parasitemia. Por outro lado, os pacientes permanecem reativos nos testes sorológicos de rotina. Nesta fase, as pessoas infectadas que moram em áreas endêmicas são reservatórios importantes do parasita (WHO, 2002).

Aproximadamente 20 anos depois da infecção, cerca de $40 \%$ dos pacientes desenvolvem sinais patológicos característicos da doença de Chagas, como cardiomiopatia, danos do sistema nervoso periférico e disfunção do sistema digestivo que conduz ao megaesôfago e/ou megacólon (WHO, 2002). 
Variações geográficas na prevalência das formas clínicas e morbidade da doença de Chagas foram reportadas. A patologia digestiva associada a $T$. cruzi predomina no Chile e Brasil Central, sendo pouco freqüente nos países do norte da América do Sul e, aparentemente, inexistente na América Central e México. Na região Amazônica, a doença parece ser mais leve que em outras áreas endêmicas, verificando-se com maior freqüência a forma indeterminada (ZINGALES et al., 1998; COURA et al., 2002). Estas diferenças geográficas podem estar relacionadas, em parte, com aspectos genéticos e de competência da resposta imune das populações humanas. Por outro lado, acredita-se que a diversidade genética dos isolados de $T$. cruzi desempenha um papel importante na definição da apresentação clínica na fase crônica da doença de Chagas.

Nos últimos 15 anos, muitos países da America Latina têm dirigido estratégias para prevenir a transmissão da doença de Chagas por transfusão sangüínea. Quatro países fazem análises sorológicas em 100\% dos doadores em Bancos de Sangue desde 1993-1995; cinco países, desde 1997; sete países, desde 2001-2002 (SCHMUNIS, 2007); e doze, a partir de 2004 (PAHO, 2006). A monitoração da transmissão transplacentária não tem sido realizada em muitos países da América Latina. As taxas de infecção congênita variam grandemente, sendo aceito que nos países do Cone Sul entre 1 a 12\% dos neonatos de mães infectadas podem estar contaminados com T. cruzi (CARLIER e TORRICO, 2006).

O número estimado de indivíduos infectados em áreas endêmicas da América Latina é de aproximadamente 15 milhões, sendo registradas de 50.000 a 200.000 novas infecções por ano (TARLETON et al., 2007). O número de mortes atribuídas à infecção pelo T. cruzi diminuiu de 50.000 mortes por ano em 1980 (KIRCHHOFF et al., 2004) para 14.000 em 2001 (WORLD BANK, 2006), indicando que a doença de Chagas está retrocedendo na América Latina. No entanto, fatores econômicos e/ou políticos têm aumentado a migração de pessoas de países endêmicos da doença de Chagas para outros países, onde são detectados casos de infecção humana através de transfusões de sangue, transplante de órgãos infectados e infecção congênita (SCHMUNIS, 2007a), transformando a doença de Chagas de um problema rural da América Latina, para um problema global (SCHMUNIS, 2007).

Existem várias classificações das manifestações clínicas da doença de Chagas. A Organização Mundial da Saúde (WHO, 2002) sugeriu uma classificação 
baseada na presença e severidade dos sintomas. Esta classificação não utiliza exames refinados, sendo útil para fins epidemiológicos, mas não para estudos clínicos ou imunológicos.

Numa reunião de especialistas, realizada em Belo Horizonte em 2003, foi proposta uma classificação clínica da cardiomiopatia chagásica crônica com critérios definidos. Esta classificação está baseada em medidas objetivas da função cardíaca, utilizando técnicas padrão, como eletrocardiograma (ECG) e radiografia $(R X)$ de tórax e técnicas de maior sensibilidade (Ecocardiografia Doppler, monitoramento por Holter de 24 horas) tendo sido definidos seis grupos clínicos (ROCHA et al., 2003):

(i) Forma crônica indeterminada: Paciente assintomático, sem alteração significativa ao exame físico. Apresentando ECG, RX de tórax, esofagograma, Holter e ecocardiograma normais.

(ii) CCC 1: Paciente assintomático, sem alteração significativa ao exame físico. Apresentando ECG, RX de tórax, esofagograma e enema de bário normais. Técnicas mais sensíveis podem detectar anormalidades cardíacas. O paciente não apresenta aumento do tamanho do coração.

(iii) CCC 2: Paciente assintomático. Alguns apresentam NYHA (New York Heart Association) funcionais classe I, sem sinais clínicos nem radiológicos de aumento do tamanho do coração, com alterações menores de ECG (como baixa voltagem de QRS, bloqueio de ramo esquerdo e mudanças menores no segmento $T$ e na onda T).

(iv) CCC 3: Paciente sem manifestações de falha cardíaca ou em NYHA funcional classe II, sem aumento do tamanho do coração. O paciente pode apresentar alterações consideráveis de ECG, bloqueio de ramo direito e contrações ventriculares uniformes prematuras.

(v) CCC 4: Paciente sem sinais de aumento do tamanho cardíaco, anormalidades de ECG severas que incluem bloqueio de ramo direito, associado a hemibloqueio anterior esquerdo, onda $\mathrm{Q}$ anormal, onda $\mathrm{T}$ simétrica negativa difusa, bloqueio de ramo esquerdo, segundo grau de bloqueio atrioventricular Mobitz tipo II e bloqueio AV completo. 
(vi) CCC 5: Paciente com sinais clínicos, radiológicos e ecocardiográficos de aumento do tamanho do coração, com ou sem manifestação de insuficiência cardíaca.

A doença de Chagas é uma entidade heterogênea com uma ampla variação no curso clínico e no prognóstico. Rassi et al. (2006) desenvolveram um modelo de predição de risco de morte em pacientes com Cardiopatia Chagásica Crônica (CCC), determinado pela presença de seis características clínicas. Em ordem decrescente de importância: (i) NYHA classe III ou IV; (ii) Radiografia: cardiomegalia; (iii) Ecocardiografia: anormalidades na mobilidade segmental ou global das paredes; (iv) Holter: taquicardia ventricular não sustentada; (v) ECG: QRS de baixa voltagem; (vi) sexo masculino.

\subsubsection{Variabilidade genética das populações de $T$. cruzi}

As populações de $T$. cruzi (também denominadas cepas) mostram um elevado grau de variabilidade intraespecífica detectada por marcadores biológicos, bioquímicos, imunológicos e genéticos (MACEDO et al., 2001). Dentre as características fenotípicas destacam-se diferenças morfológicas, de infectividade em modelos experimentais, tropismo tissular e suscetibilidade a quimioterápicos. Estudos iniciais baseados na variabilidade isoenzimática de seis loci classificaram as populações de $T$. cruzi em três zimodemas maiores denominados Z1, Z2 e Z3 (MILES et al., 1978). Posteriormente, foram analisados 15 loci de isoenzimas evidenciando maior diversidade genética e 43 genótipos foram propostos (TIBAYRENC et al., 1986; TIBAYRENC e AYALA, 1988).

Estudos moleculares baseados no dimorfismo de regiões do gene de miniéxon e do gene de RNA ribossômico (rRNA) 24Sa propuseram a divisão do táxon $T$. cruzi em dois grupos principais (SOUTO et al., 1996; FERNANDES et al., 1998). Estes estudos também evidenciaram populações putativamente híbridas denominadas grupo de rDNA $1 / 2$ (SOUTO et al., 1996). Neste mesmo estudo, a análise da estrutura genômica de isolados de T. cruzi por RAPD (Randomly Amplified Polymorphic DNA) indicou que os dois grupos representam duas linhagens filogenéticas, muito distantes uma da outra (SOUTO et al., 1996). Em 1999, um 
comitê de expertos reunido no Rio de Janeiro decidiu homogeneizar a nomenclatura das duas linhagens que passaram a serem denominadas grupos $T$. cruzi I e T. cruzi II (ANÔNIMO, 1999). Estes grupos estariam associados aos ciclos de transmissão silvestre ( $T$. cruzi I/Z1) e doméstico ( $T$. cruzi II/Z2) (MILES et al., 1978; ZINGALES et al., 1998). O comitê também determinou que a classificação dos isolados do zimodema 3 e do grupo de rDNA $1 / 2$ deveria aguardar maiores estudos.

Posteriormente, Tibayrenc e colaboradores propuseram que o grupo T. cruzi II estaria dividido em cinco subgrupos ou Unidades de Tipificação Discreta (DTUs) designadas Ila, Ilb, Ilc, Ild e Ile (BRISSE et al., 2000; 2003). As DTUs Ila e Ilc, corresponderiam ao zimodema 3; ao passo que a DTU Ild corresponderia ao grupo de rDNA 1/2. Foi proposto que as DTUs lla e Ilc seriam o resultado de um evento de hibridização relativamente antigo entre as cepas das DTUs I e Ilb; e que as DTUs Ild e lle seriam o produto de uma hibridização mais recente e teriam alelos similares àqueles encontrados nas DTUs IIb e Ilc (WESTENBERGER et al., 2005). A cepa de referência do projeto genoma de T. cruzi, CL Brener, é um membro da DTU Ile.

O zimodema 3 (Z3), originalmente descrito na região Amazônica, está associado ao ciclo silvestre de transmissão (MILES et al., 1978). Análises moleculares do espaçador transcrito intergênico do cístron de rDNA e do domínio divergente D7 do gene de rRNA 24Sa permitiram verificar que o grupo Z3 está dividido em dois grupos discretos denominados Z3-A e Z3-B (MENDONÇA et al., 2002), que correspondem, respectivamente às DTUs Ilc e Ila (WESTENBERGER et al., 2005).

Mais recentemente, com base em marcadores moleculares adicionais, foi proposto que o táxon $T$. cruzi estaria dividido em três linhagens principais (AUGUSTO-PINTO et al., 2003; SANTOS et al., 2002; FREITAS et al., 2006). No grupo T. cruzi III estriam incluídas as cepas híbridas de Z3. Um estudo baseado na seqüência dos genes nucleares tripanotiona redutase (TR) e diidrofolato redutasetimidilato sintase (DHFR-TS) e de uma região do DNA mitocondrial que abarca os genes que codificam a subunidade II da citocromo oxidase (CO II) e a subunidade I da NADH desidrogenase (NDI) mostrou a presença de três clados em T. cruzi (A, B e C) (MACHADO e AYALA, 2001). O Clado A corresponderia à DTU I; o Clado $B$, às DTUs Ila, Ilc, Ild e Ile; e o clado C, à DTU Ilb (BRISSE et al., 2003). 
Uma questão que há muito tempo permeia a comunidade que estuda a doença de Chagas é se as diferentes manifestações clínicas estão associadas a determinadas características genéticas das populações infectantes.

Uma associação entre tropismo tissular e determinados clones do parasita foi demonstrada em humanos, com possíveis implicações na patologia da doença de Chagas (VAGO et al., 1996). Andrade et al. (1999) utilizaram a técnica de LSSPPCR (Low Stringency Single Primer-PCR) em modelos murinos duplamente infectados com a cepa JG ( $T$. cruzi II) e o clone Col 1.7G2 ( $T$. cruzi I), e demonstraram a prevalência da cepa JG no coração e do clone Col 1.7G2 no intestino. A presença de $T$. cruzi II em lesões cardíacas e de megaesôfago de diferentes pacientes chagásicos também foi demonstrada (FREITAS et al., 2005).

Em um estudo onde foram genotipados isolados obtidos de insetos triatomíneos, reservatórios silvestres e humanos originários de doze estados brasileiros concluiu-se que o grupo $T$. cruzi I predomina no ciclo silvestre da transmissão, ao passo que o grupo $T$. cruzi Il está associado ao ciclo doméstico e determina a doença de Chagas em humanos (ZINGALES et al., 1998; FERNANDES et al., 1998). Estas conclusões corroboram dados anteriores que associam ao zimodema Z2 a alta incidência de lesões cardíacas na Argentina (MONTAMAT et al., 1996) e da forma digestiva no Brasil Central (LUQUETTI et al., 1986). Estes e outros resultados têm sido usados como evidência de que o humano poderia atuar como filtro biológico, selecionando determinados genótipos de uma mistura de populações infectantes (MACEDO et al., 2004).

A genotipagem baseada em curvas de desnaturação do domínio D7 do gene de rRNA 24Sa de cepas isoladas do coração, esôfago e cólon de pacientes de cidades do estado de Minas Gerais demonstrou apenas a presença do grupo T. cruzi II (FREITAS et al., 2005).

Por outro lado, o grupo $T$. cruzi I foi descrito em humanos na fase aguda e crônica da doença de Chagas em países da América Central, do norte da América do Sul e na região Amazônica brasileira (AÑEZ et al., 2004; TEIXEIRA et al., 2006). Isto sugere que os isolados de $T$. cruzi I que circulam nestas regiões também podem causar a doença, seja por eles serem geneticamente diferentes dos isolados de mesmo grupo que predominam em países do Cone Sul, seja por características 
específicas das populações humanas que habitam estas regiões. Este aspecto certamente deverá ser esclarecido.

É importante ter em mente que alguns pacientes podem estar infectados com mais de uma população de T. cruzi (VAGO et al., 2000), e que os isolados obtidos por hemocultura e de determinados órgãos podem não representar a totalidade dos clones infectantes. Como resultado de uma baixa parasitemia, diferentes populações do parasita com distintos tropismos tissulares podem não ser detectadas, sendo possível que alguns clones sejam selecionados pelas técnicas de isolamento disponíveis (LAGES-SILVA et al., 2006).

A seguir, faremos uma breve revisão de tópicos relacionados com o tema desta tese: metabolismo intermediário, funções e genoma mitocondrial e controle da expressão gênica.

\subsection{ALGUMAS CARACTERÍSTICAS DO METABOLISMO DE T. cruzi}

\subsubsection{Visão geral do Metabolismo Intermediário}

Os tripanossomatídeos parasitas apresentam um ciclo de vida digenético, com mudanças morfológicas complexas na sua passagem por um ou mais hospedeiros vertebrados e por insetos vetores hematófagos. Estes dois ambientes muito diferentes determinaram o aparecimento de inúmeras características adaptativas.

A maior parte dos tripanossomatídeos, se não todos, dependem da disponibilidade de fontes de carbono presentes em seus hospedeiros para seu metabolismo energético. Os insetos hematófagos obtêm sua energia predominantemente de L-prolina ou L-glutamina, os maiores constituintes de sua hemolinfa e fluidos tissulares (BURSELL, 1981) e, conseqüentemente, os estágios dos tripanossomatídeos presentes no inseto dependem do catabolismo de aminoácidos, com preferência para L-prolina (CANNATA e CAZZULO, 1984; MARR et al., 1977; LAMOUR et al., 2005). Deve-se ressaltar que T. cruzi (mas não 
Leishmania e T. brucei) expressa uma prolina racemase que permite utilizar, além de L-prolina, D-prolina (CHAMOND et al., 2003; ATWOOD et al., 2005).

As formas epimastigotas de T. cruzi, cultivadas em meios com glicose e aminoácidos, consomem preferencialmente glicose (CAZZULO et al., 1985; LAMOUR et al., 2005). O mesmo se verifica com as formas tripomastigotas de $T$. brucei e $T$. cruzi que também utilizam glicose por ser abundante nos fluidos de seus hospedeiros vertebrados (CANNATA e CAZZULO, 1984).

A fonte de carbono utilizada por estágios intracelulares depende do compartimento específico onde eles vivem. Os amastigotas de T. cruzi e Leishmania usam a abundante disponibilidade de aminoácidos para seu metabolismo energético, envolvendo vias mitocondriais (TIELENS e VAN HELLEMOND, 1998; BRINGAUD et al., 2006). Foi mostrado que L-prolina é indispensável para a diferenciação das formas amastigotas intracelulares em epimastigotas-símile e, posteriormente, em tripomastigotas (TONELLI et al., 2004).

O metabolismo dos tripanossomatídeos é um tema que vem sendo ativamente estudado desde meados do século passado. Dois eventos recentes aceleraram este estudo: (i) os projetos de seqüenciamento do genoma de T. brucei, T. cruzi e L. major, completados em 2005 (BERRIMAN et al., 2005; EL-SAYED et al., 2005; IVENS et al., 2005), que forneceram ferramentas poderosas para determinar a complexidade metabólica destes organismos e (ii) a técnica de genética reversa de RNA de interferência (RNAi) que inibe especificamente a expressão de um determinado gene e que permite investigar os efeitos promovidos por este silenciamento. A técnica de RNAi foi desenvolvida em T. brucei (NGO et al., 1998; WANG et al., 2000) e, recentemente, foi também aplicada em L. braziliensis (PEACOCK et al., 2007). Infelizmente, tanto T. cruzi como outras espécies de Leishmania (ULLU et al., 2004) não possuem a maquinaria de RNAi. Conseqüentemente, as formas procíclicas de $T$. brucei tornaram-se o modelo favorito para estudos do metabolismo. Por outro lado, muitos dos processos elucidados nos tripanossomas africanos são compartilhados por outras espécies de tripanossomatídeos (BESTEIRO et al., 2002).

Uma revisão recente, focada principalmente em $T$. brucei, discute 0 metabolismo energético dos tripanossomatídeos e sua adaptação para as fontes de 
carbono disponíveis (BRINGAUD et al., 2006). Na figura 1 (retirada desta revisão) apresenta-se uma visão geral do metabolismo intermediário destes organismos.

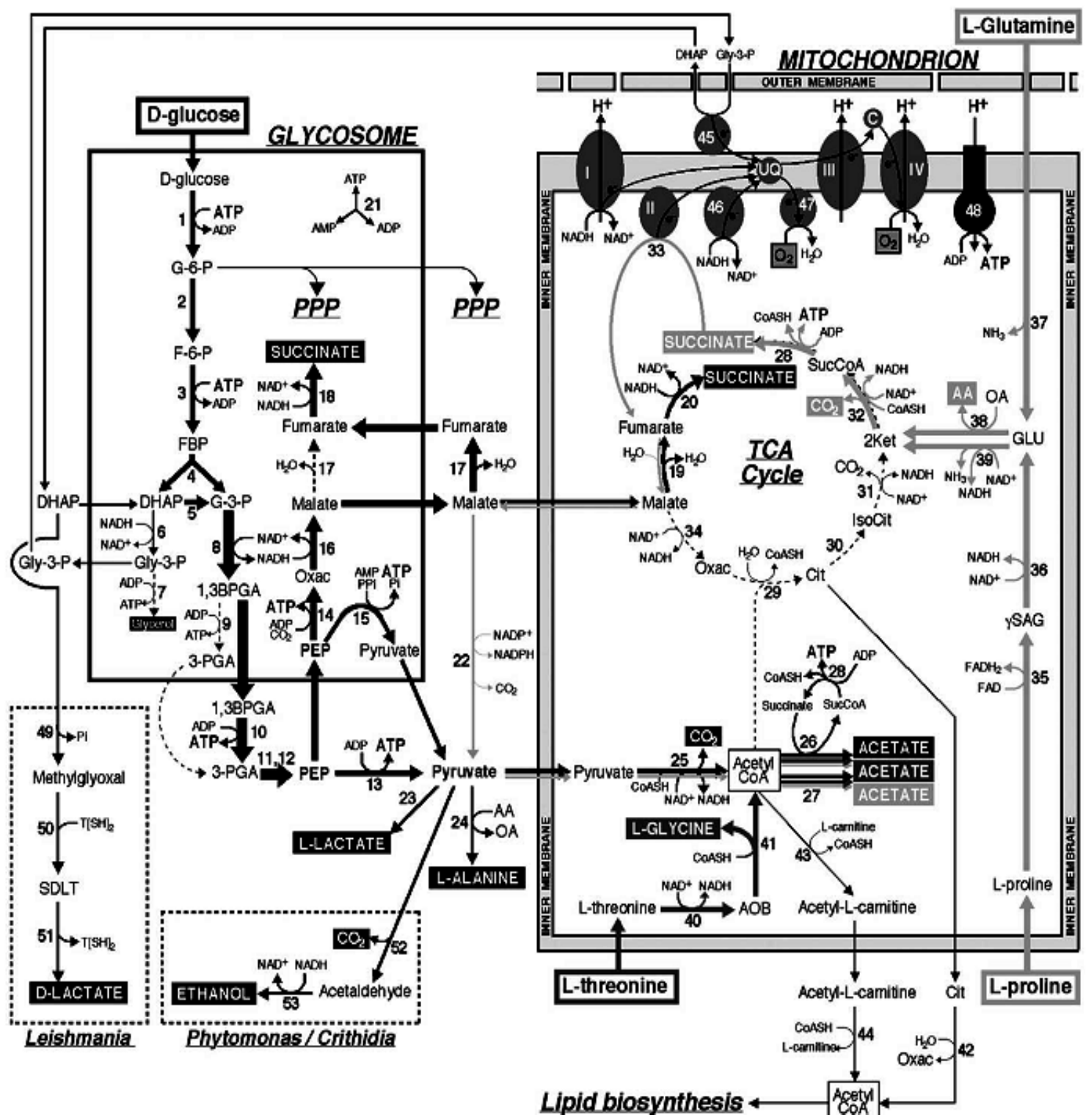

Figura 1. Visão geral do metabolismo intermediário de tripanossomatídeos. Salientam-se os dois compartimentos celulares: o glicossomo e a mitocôndria. FONTE: Modificado de Bringaud et al., 2006.

NOTA: Os números indicam as enzimas, cujos nomes constam no artigo citado. 


\subsubsection{Transporte e utilização de carboidratos, proteínas e aminoácidos}

É conhecido que formas epimastigotas de T. cruzi podem consumir ativamente carboidratos e aminoácidos do meio, excretando catabólitos reduzidos de glicose, principalmente succinato e amônia (CAZZULO, 1994). T. cruzi não apresenta reservas intracelulares de glicose, como glicogênio ou amido. Por conseguinte, a glicose é importada constantemente do meio externo (como por exemplo a partir do sangue de mamíferos) através de transportadores de hexoses dos quais em Leishmania spp foram descritos três, em T. brucei dois (SILBER et al., 2005) e em T. cruzi um (MILETTI et al., 2006).

Ao contrário da maior parte dos eucariotos onde a glicólise ocorre no citoplasma, nos tripanossomatídeos esta via está confinada em uma organela denominada glicossomo. No glicossomo foram identificadas sete enzimas envolvidas na degradação da glicose e duas na via do glicerol (MICHELS et al., 2006) (ver Figura 2). Grande parte destas enzimas foi caracterizada do ponto de vista estrutural e cinético, observando-se algumas diferenças marcantes em relação às enzimas homólogas do hospedeiro humano. Este aspecto as torna um alvo potencial para o desenho de novas drogas. No glicossomo, a molécula de glicose é convertida em duas moléculas de gliceraldeído-1,3-bisfosfato (1,3-BPGA), o qual é transportado para o citossol por um mecanismo ainda não caracterizado. O 1,3-BPGA é convertido em fosfoenol piruvato (PEP, assinalado na Fig. 2), que pode seguir duas vias: (i) ser transportado ao glicossomo, seguido de carboxilação para oxaloacetato, reação catalisada pela PEPCK (Fosfoenolpiruvato carboxiquinase; enzima 14 na Fig. 2), que leva à produção de malato. Este é desidratado para fumarato e reduzido finalmente para succinato, um dos maiores produtos de excreção em tripanossomatídeos; (ii) alternativamente, PEP pode ser convertido em piruvato, localizado num ponto de ramificação metabólica, levando a vários produtos de excreção como acetato, L-alanina e L-lactato (Figura 2). 


\subsubsection{Vias de fermentação succínica e balanço redóx}

Em muitos organismos, a transição da anaerobiose para aerobiose é acompanhada por um rápido e considerável decréscimo na taxa de utilização de glicose. Esta inibição da glicólise pelo oxigênio é denominada efeito Pasteur. Nos tripanossomatídeos, o efeito Pasteur não se verifica. Observa-se um efeito Pasteur reverso, ou seja, em condições anaeróbicas, a utilização de glicose diminui. Este processo foi denominado fermentação aeróbica ou fermentação succínica para enfatizar que os produtos liberados no meio são produtos fermentativos similares àqueles produzidos por outros organismos em condições anaeróbicas (lactato, por exemplo), mas sua produção ocorre em presença de oxigênio (CAZZULO, 1992).

O uso de carboidratos como fonte de carbono e energia por todos os estágios do ciclo de vida de $T$. cruzi apresenta uma série de características inusitadas:

(i) em presença de grandes concentrações externas de carboidratos, o parasita degrada de forma incompleta estas substâncias, inclusive em presença de oxigênio, para dar uma mistura de $\mathrm{CO}_{2}$ e produtos finais reduzidos como ácidos mono e dicarboxílicos, dos quais succinato representa $\sim 70 \%$ dos produtos finais excretados (COUSTOU et al., 2008) e, em menores quantidades, outros compostos como alanina e acetato (ver Fig. 2). Isto ocorre apesar de estas células terem ativas a via glicolítica, o ciclo de Krebs e a cadeia de transporte de elétrons; (ii) a via glicolitica, que ocorre no glicossomo, não é regulada nos seus clássicos pontos de controle (hexoquinase e fosfofrutoquinase); (iii) o crescimento de epimastigotas num meio complexo é suportado inicialmente pelo rápido mas incompleto uso de carboidratos, sendo que o maior incremento de biomassa ocorre depois da completa depleção dos carboidratos disponíveis (URBINA, 1994).

Em tripanossomatídeos, o succinato é produzido no glicossomo (ver Figura 2) e na mitocôndria (ver Figura 3), por duas isoformas de fumarato redutase (FRD) dependentes de NADH, denominadas FRDg e FRDm, respectivamente (BESTEIRO et al., 2002; COUSTOU et al., 2005; COUSTOU et al., 2006). 


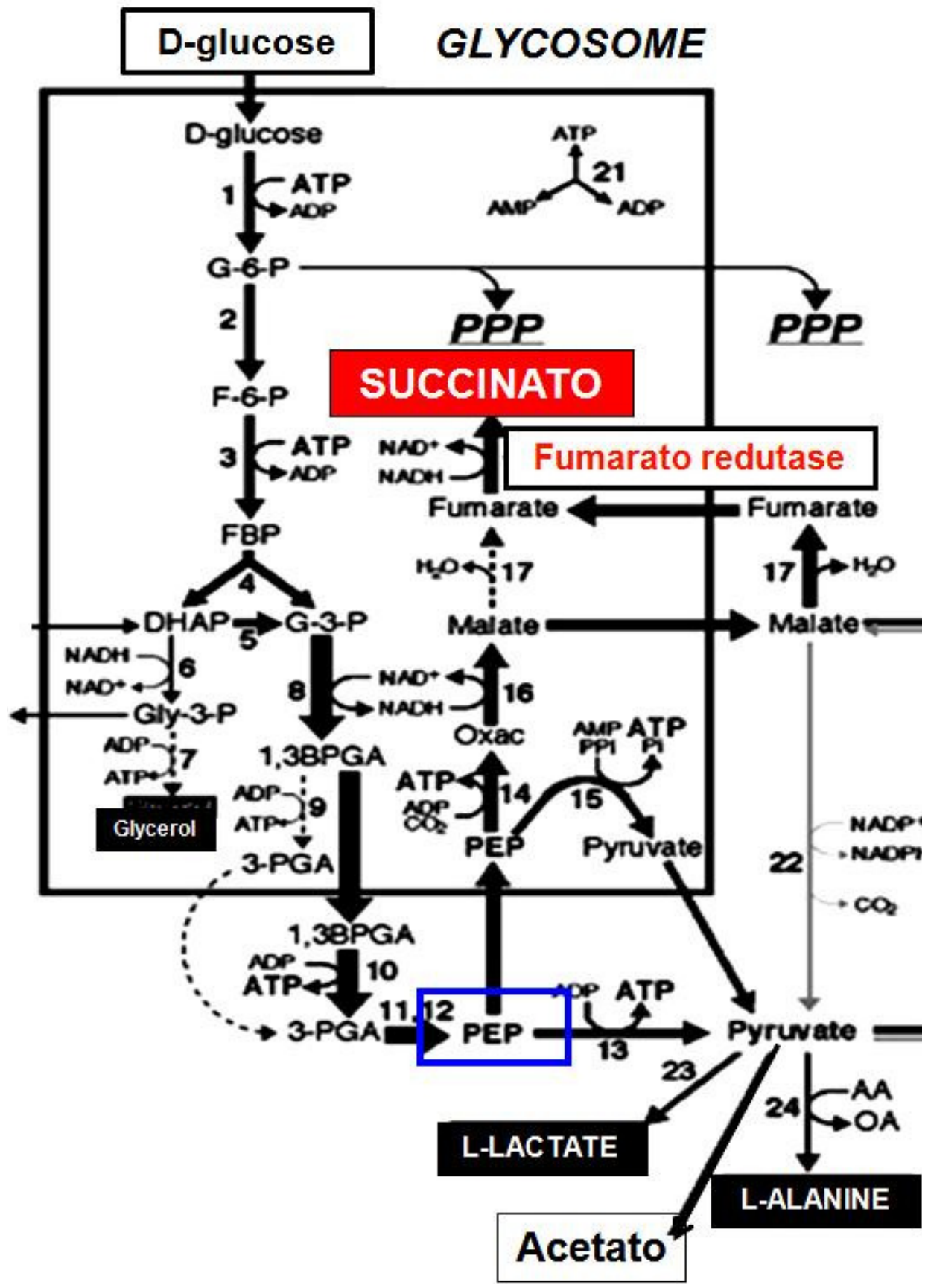

Figura 2. Visão geral das reações metabólicas que ocorrem no glicossomo.

FONTE: Modificado de Bringaud et al., 2006.

NOTA: Os números indicam as enzimas, cujos nomes constam no artigo citado. 
A reação catalisada pela fumarato redutase é:

$$
\text { Fumarato }+\mathrm{NADH}+\mathrm{H}^{+} \rightleftarrows \text { Succinato }+\mathrm{NAD}^{+}
$$

Fumarato redutases estão presentes em todos os estágios de desenvolvimento de T. cruzi (TURRENS et al., 1992), em vários outros membros do gênero Trypanosoma, e não foram encontradas em células de mamíferos (BOVERIS et al., 1986). No genoma de T. cruzi encontramos dois genes putativos de FRD (GenBank: XM802227 e XM797953.1) que apresentam domínios mitocondriais (COUSTOU et al., 2005).

As FRDs podem ser divididas em duas classes: (i) complexos multiméricos associados à cadeia respiratória e (ii) enzimas solúveis que não estão associadas à cadeia respiratória e não participam na fosforilação oxidativa. Só se conhecem dois organismos que apresentam FRDs solúveis: Saccharomyces cerevisiae, que expressa duas formas (citossólica e pró-mitocondrial) (ARIKAWA et al., 1998), e T. brucei, que expressa FRDs glicossomais (FRDg) e mitocondriais (FRDm) (DENICOLA-SEOANE et al., 2002; BESTEIRO et al., 2005).

\subsubsection{Via das Pentoses Fosfato (PPP)}

A via das pentoses fosfato é uma via alternativa de oxidação de glicose, que leva à produção de dois compostos importantes: ribose-5-fosfato e NADPH. Esta coenzima atua como doadora de hidrogênio em sínteses redutoras (p. ex. síntese de ácidos graxos e colesterol) e em reações de proteção contra agentes oxidantes. NADPH não é substrato para a cadeia de transporte de elétrons e sua oxidação é feita em vias de síntese.

A via das pentoses fosfato é operativa em $T$. cruzi e as sete enzimas que a constituem estão presentes em todos os estágios do seu ciclo de vida. O NADPH formado é indispensável na proteção das células contra o "stress" oxidativo imposto por espécies reativas de oxigênio (EROs) (MAUGERI e CAZZULO, 2004). Neste 
sistema, atua a Tripanotiona que é mantida no estado reduzido pela tripanotiona redutase que usa NADPH como co-fator (TRUJILLO et al., 2004).

Nos tripanossomatídeos, as enzimas da via PPP ocorrem tanto no glicossomo quanto no citossol (HEISE et al., 1999; DUFFIEUX et al., 2000). Esta característica poderia ser explicada pelas seguintes evidências: (i) a via glicolítica e da PPP podem trocar intermediários para ajustar as necessidades celulares de ATP; (ii) o produto final, ribose-5-fosfato, é convertido em 5-ribosil-1-pirofosfato que é utilizado na síntese de purinas e pirimidinas, processo que ocorre nos glicossomos; (iii) as enzimas envolvidas na defesa contra EROs são encontradas em ambos compartimentos (WILKINSON et al., 2002a).

Os níveis das enzimas da via PPP são substancialmente altos nos estágios de T. cruzi presentes no hospedeiro mamífero e naqueles prontos para invadi-lo (tripomastigotas metacíclicos). Isto pode estar relacionado à possível exposição do parasita ao "stress" oxidativo verificado no hospedeiro mamífero e pode ser particularmente importante para os amastigotas de cepas reticulotrópicas que residem em macrófagos (MAUGERI e CAZZULO, 2004).

\subsubsection{Metabolismo de proteínas e aminoácidos}

Os epimastigotas de $T$. cruzi podem obter aminoácidos por transporte ativo do meio de cultivo (CANNATA e CAZZULO, 1984); biossíntese a partir de precursores metabólicos ou pela degradação de proteínas adquiridas por pinocitose. Foi observado que os epimastigotas degradam preferencialmente glicose e que passam

a metabolizar aminoácidos apenas quando aquela fonte de carbono foi esgotada (CAZZULO, 1994).

As proteínas e aminoácidos podem ser uma reserva energética para os parasitas, que sob algumas circunstâncias, como por exemplo, na diferenciação de epimastigotas para tripomastigotas, os utilizam como combustível numa proporção significativa (TONELLI et al., 2004). Os reservossomas, organelas específicas dos epimastigotas, contêm as proteínas ingeridas e também a cruzipaína, uma cisteínoprotease que desaparece junto com os reservossomas durante a diferenciação para tripomastigotas metacíclicos (SOARES et al., 1992). 
T. cruzi pode metabolizar aminoácidos como asparagina, glutamina, aspartato, glutamato, leucina e prolina. Todos estes aminoácidos são oxidados através de sua conversão para glutamato ou aspartato, que podem ser transportados do citoplasma para a mitocôndria e processados pelo ciclo de Krebs. O grupo amino do glutamato pode ser transferido para piruvato por ALAT (alanina aminotransferase) formando alfa-cetoglutarato. Ademais, em alguma magnitude, TAT (Tirosina Aminotransferase) pode transferir o grupo amino do glutamato para piruvato gerando alanina. Outra via onde o glutamato pode ser convertido para alfacetoglutarato, é através da glutamato desidrogenase, que apresenta duas isoformas, uma mitocondrial e outra citoplasmática, transferindo o grupo amino para a água, o que explicaria a alta concentração de amônia nos meios de cultivo (SILBER et al., 2005). Esta enzima pode participar também na biossíntese de aminoácidos ao incorporar amônia a alfa-cetoglutarato gerando glutamato (CALDAS et al., 1980). Glutamato e oxalacetato também podem ser gerados pela transferência de grupos amino do aspartato para alfa-cetoglutarato através da aspartato aminotransferase. $\mathrm{O}$ glutamato assim obtido pode prosseguir para o ciclo de Krebs (CAZZULO et al., 1977).

Alanina assim como os três aminoácidos aromáticos podem ser transaminados por TAT que também apresenta atividade aspartato aminotransferase. Entre os grupos aceptores estão em primeira instância o piruvato, que é convertido a alanina (FRYDMAN et al., 1990); alfa-cetoglutarato, convertido a glutamato, e oxalacetato, convertido a aspartato (MONTEMARTINI et al., 1995). TAT catalisa também uma transaminação reversível entre aspartato ou alanina e os aminoácidos aromáticos pelo qual parece ter também uma função chave na biossíntese destes aminoácidos. Glutamina também pode ser sintetizada a partir de glutamato e amônia pela glutamina sintase (CALDAS et al., 1980).

Arginina também é um aminoácido chave para as vias metabólicas, no entanto, $T$. cruzi é incapaz de sintetizá-lo, sendo obtido através de pelo menos dois sistemas de transporte, um de alta afinidade, altamente específico e dependente de ATP e outro de baixa afinidade, competindo fortemente por metionina, lisina e tirosina. A fosfoarginina (conhecido fosfágeno) tem um papel crítico na reserva energética porque os fosfatos de alta energia podem ser transferidos para ADP quando é necessária a renovação de ATP (PEREIRA et al., 2000). Tem sido 
proposto que a fosfoarginina pode suportar a atividade celular até que eventos metabólicos, como glicólise e fosforilação oxidativa sejam ativados. A arginina quinase catalisa a transformação reversível entre $\mathrm{N}$-fosfo-L-arginina e ADP (ELLINGTON, 2001). A arginina quinase é importante no aporte de energia para o parasita e está ausente em tecidos de mamíferos, isto a converte num alvo terapêutico importante (SILBER et al., 2005).

A prolina é um importante metabólito para os tripanossomatídeos e pode ser utilizada como uma fonte principal de carbono e energia (CAZZULO, 1994). No caso particular do estágio epimastigota encontrado no inseto vetor, o crescimento na fase exponencial e estacionária tardia é principalmente centrado no consumo de Lprolina. De fato, Sylvester e Krassner (1976) demonstraram que L-prolina podia oxidar-se depois da inanição e metabolizar-se através do ciclo de Krebs. L-prolina também pode atuar como um osmorregulador, participando na resposta à pressão osmótica como um osmólito importante (YOSHIBA et al., 1997) quando T. cruzi circula nos diferentes ambientes como o intestino médio do inseto, o sangue do mamífero ou está no citoplasma das células do hospedeiro (BURSELL et al., 1996). O achado de uma prolina racemase citoplásmica no parasita reforça a importância metabólica da prolina (REINA-SAN MARTIN et al., 2000). Particularmente importante é o envolvimento de L-prolina no processo de metaciclogênese, ou seja, a diferenciação das formas epimastigotas replicativas não infectantes para tripomastigotas metacíclicos, as formas não replicativas e infectantes (CONTRERAS et al., 1985; HOMSY et al., 1989). Tonelli et al. (2004) descreveram o papel essencial da L-prolina na diferenciação intracelular das formas amastigotas e epimastigotas- símile em tripomastigotas sangüíneos.

Em T. cruzi foram encontradas pelo menos seis isoformas de cistationa sintase com atividade serina-acetil transferase que pode converter serina em cisteína. A recuperação de $\mathrm{CO}_{2}$ marcado radiativamente em epimastigotas incubados com serina $\left({ }^{14} \mathrm{C}\right)$ pode apoiar a idéia de uma oxidação parcial de serina através do ciclo de Krebs (NOZAKI et al., 2001). 


\subsubsection{Geração de ATP}

Em muitas formas adaptativas de tripanossomatídeos está presente uma completa maquinaria enzimática voltada para o metabolismo oxidativo. Isto inclui uma cadeia de transporte de elétrons funcional, que contém citocromos, dentre outros componentes, capaz de gerar um gradiente de prótons que é utilizado pela $F_{1} F_{0}$-ATP sintase para a produção de ATP. Este foi considerado durante muitos anos o maior sítio de produção de ATP nestes organismos. (Nota: mais adiante faremos uma breve revisão sobre a cadeia de transporte de elétrons de $T$. cruzı).

$O$ papel da $F_{1} F_{0}$-ATP sintase na produção de energia sob condições de abundância de glicose tem sido questionado (BOCHUD-ALLEMANN et al., 2002; BESTEIRO et al., 2005). De fato, um excesso de oligomicina, um inibidor clássico de $\mathrm{F}_{1} \mathrm{~F}_{\mathrm{o}}$-ATP sintase, não afeta a viabilidade de formas procíclicas de $T$. brucei, sendo necessárias doses muito maiores desta droga para matar as células num meio rico em glicose (COUSTOU et al., 2003). No entanto, quando os parasitas crescem em meios pobres em glicose, tornam-se 1000 vezes mais sensíveis a oligomicina. Isto suporta a idéia de que, em presença de glicose, as formas procíclicas não são dependentes da fosforilação oxidativa para a produção de ATP. No entanto, na ausência de glicose, quando as células mudam para o catabolismo de aminoácidos, a fosforilação oxidativa é essencial (BESTEIRO et al., 2005). Estes dados também sugerem que num meio rico em glicose, muito do ATP é produzido por fosforilação no nível do substrato com um papel chave da fosfoglicerato quinase (PGK), piruvato quinase (PYK) e succinil CoA sintase mitocondrial (SucCoS). De fato, considerando a taxa de glicose e/ou de prolina adquirida e o número de moléculas consumidas, estima-se que a produção líquida de ATP por fosforilação no nível do substrato seja três vezes maior num meio rico em glicose (BRINGAUD et al., 2006). Isto sugere que a $F_{1} F_{0}$-ATP sintase mitocondrial tenha um papel menor na produção de ATP (BRINGAUD et al., 2006).

É desconhecido o mecanismo pelo qual os tripanossomatídeos regulam a fosforilação oxidativa. No entanto, o nível de substratos disponíveis, oxigênio, ADP e equivalentes reduzidos podem ter um papel importante, assim como o grau de acoplamento entre a respiração e a fosforilação oxidativa. Neste sentido, nos eucariotos dois processos regulatórios foram descritos: (i) um sistema dissipador do 
potencial próton-eletroquímico, representado por proteínas desacopladoras e (ii) um sistema dissipador do potencial redóx, representado por oxidases alternativas. Somente a última foi descrita em tripanossomatídeos. Neste caso, o fluxo de elétrons do ubiquinol (coenzima $Q$ ) para a oxidase alternativa de tripanossomas (TAO) não está acoplado à produção de ATP (BRINGAUD et al., 2006) (ver Figura 3, enzima 47). Este sistema pode prover grande flexibilidade para modular a geração do gradiente de prótons e, assim, regular a fosforilação oxidativa (BRINGAUD et al., 2006).

As TAO são oxidases terminais, independentes dos citocromos da cadeia respiratória mitocondrial, que transferem elétrons do ubiquinol para o oxigênio, com formação de água. Esta reação não está acoplada à translocação de prótons e produção de ATP na mitocôndria. Estas enzimas foram descritas inicialmente em formas sanguíneas de $T$. brucei e foram denominadas Sistema GPO (Sistema Glicerol-3-fosfato Oxidases). Posteriormente foram denominadas TAO. São inibidores específicos de TAO o ácido salicil hidroxâmico (SHAM) e a ascofurona (CHAUDHURI et al., 2006).

A presença de TAO em $T$. cruzi foi sugerida a partir da observação de que SHAM inibe o consumo de oxigênio em epimastigotas (FELIX et al., 1978; STOPPANI et al., 1980; ENGEL et al., 1990) e a oxidação direta de glicerol fosfato por extratos mitocondriais (CONCEPCION et al., 2001).

O cDNA de TAO de T. brucei, T. vivax e T. congolense foi clonado. Em T. cruzi não foram encontrados homólogos de TAO, por inspeção dos dados do genoma. Foi identificada uma seqüência TAO-símile que carece do motivo de união a ferro e que apresenta cerca de $19 \%$ de identidade e similaridade com a TAO dos tripanossomas africanos (GenBank: TC00.1047053504147.180). Esta seqüência TAO-símile também foi detectada na cepa TC221 de T. brucei (CHAUDHURI et al., 2006). 


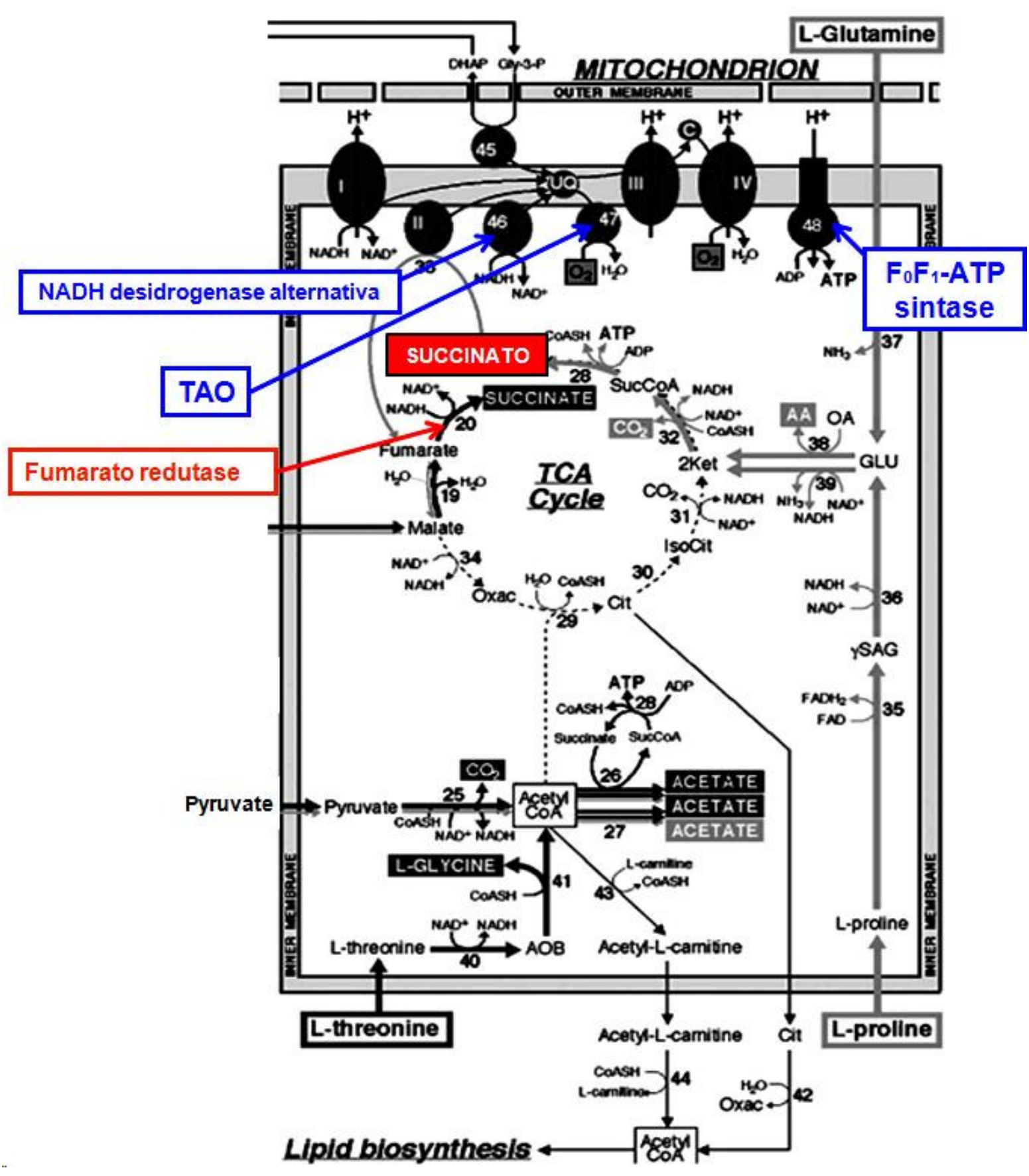

Figura 3. Visão geral das reações metabólicas que ocorrem na mitocôndria. Números romanos I, II, III e IV indicam os complexos da cadeia de transporte de elétrons.

FONTE: Modificado de Bringaud et al., 2006.

NOTA: Os números arábicos indicam as enzimas, cujos nomes constam no artigo citado. 


\subsubsection{Geração de Espécies Reativas de Oxigênio (EROs) e mecanismos de defesa}

Muitos protozoários parasitas são células aeróbicas, que utilizam oxigênio molecular como aceptor de elétrons, gerando moléculas de água na mitocôndria. Acoplado a este processo ocorre a síntese de ATP. O oxigênio molecular também pode ser parcialmente reduzido para espécies relativamente estáveis, aceitando um, dois ou três elétrons, gerando, respectivamente, o radical superóxido $\left(\mathrm{O}_{2}{ }^{\circ}\right)$, peróxido de hidrogênio $\left(\mathrm{H}_{2} \mathrm{O}_{2}\right)$ e radicais hidroxila $\left(\mathrm{OH}^{\circ}\right)$. Estas espécies são denominadas Espécies Reativas de Oxigênio (EROs). O ânion superóxido e peróxido de hidrogênio resultam usualmente de reações redóx, mas também podem ser produzidos por atividade antimicrobiana e na sinalização celular.

EROs são compostos instáveis e reagem rapidamente com outros radicais livres e macromoléculas em reações em cadeia, gerando um incremento prejudicial de oxidantes. $O$ efeito tóxico de EROs é proporcional à quantidade e força oxidante. $\mathrm{O}$ peróxido de hidrogênio $\left(\mathrm{H}_{2} \mathrm{O}_{2}\right)$ não é excessivamente reativo, mas altamente difusível e precursor de $\mathrm{OH}^{\circ}$, pode passar através das membranas biológicas e afetar alvos celulares distantes (ZACKS et al., 2005), é mais estável, sendo detectado mais facilmente e permitindo determinar quantitativamente a produção de EROs nas células (MOHANTY et al., 1997).

Durante o ciclo de vida, T. cruzi é exposto a diferentes EROs geradas pelo metabolismo aeróbico do parasita, na resposta imune do hospedeiro e, ocasionalmente, produzidas por medicamentos utilizados no tratamento da doença de Chagas (TURRENS, 2004). É amplamente conhecido que a cadeia de transporte de elétrons mitocondrial é a maior fonte de produção de EROs pelos complexos respiratórios I, através dos grupos ferro-enxofre, e complexo III, por auto-oxidação de ubi-semiquinona (TURRENS e BOVERIS, 1980; TURRENS, 2003). O complexo I libera o ânion superóxido para a matriz mitocondrial, enquanto o complexo III pode liberá-lo para a matriz e o espaço intermembrana (CHEN et al., 2003).

$\mathrm{O}$ radical superóxido é dismutado rapidamente em $\mathrm{H}_{2} \mathrm{O}_{2}$ pelas Superóxido Dismutases (SOD). Estas metaloenzimas podem ser classificadas em quatro isoformas: ferro (FeSOD), cobre-zinco (Cu/ZnSOD), manganês (MnSOD) e níquel 
(NiSOD) (MILLER, 2004). Em muitos organismos foram detectadas duas ou mais isoformas de SOD, enquanto em $T$. cruzi apenas a FeSOD foi descrita, codificada por diferentes genes: FeSOD-A e FeSOD-B (TEMPERTON et al., 1996; ISMAIL et al., 1997), FeSOD-C e FeSOD-B (DUFERNEZ et al., 2006; WILKINSON et al., 2006).

Para evitar o dano celular causado por EROs, os organismos desenvolveram sistemas antioxidantes, representados por catalases, glutationa peroxidases, superóxido dismutases e peroxiredoxinas, que eliminam EROs por redução para água ou alcoóis (PIÑEYRO et al., 2005).

O sucesso da infecção num ambiente oxidante depende em grande parte da habilidade do parasita em detoxificar EROs. Apesar de os tripanossomatídeos não terem catalases e glutationa peroxidases dependentes de selênio (BOVERIS et al., 1980; FAIRLAMB et al., 1992; FLOHE et al., 1999), eles apresentam um sistema de detoxificação único, representado por enzimas dependentes do tiol da tripanotiona ( $N^{1}, N^{8}$-bis-glutatinilespermidina) (Figura 4). A tripanotiona é mantida na forma reduzida pela tripanotiona redutase (TR) (FAIRLAMB et al., 1992). A tripanotiona, por sua vez, serve como fonte de redução para a triparedoxina (TXN) (ALPHEY et al., 1999). Esta é uma pequena proteína relacionada à tioredoxina e é a doadora de elétrons para a redução de peróxidos pela triparedoxina peroxidase (TXNP) (ALPHEY et al., 2000). Desta maneira, a tripanotiona tem um papel importante no metabolismo dos tripanossomatídeos, similar ao da glutationa em outros organismos.

Em T. cruzi foram caracterizadas a triparedoxina peroxidase citossólica (TcCPX), a primeira peroxiredoxina identificada, e a triparedoxina peroxidase mitocondrial. Estas enzimas catalisam a redução de $\mathrm{H}_{2} \mathrm{O}_{2}$ usando triparedoxina como substrato reduzível, em combinação com tripanotiona, tripanotiona redutase e NADPH (WILKINSON et al., 2002). Sob condições de estresse, foi descrito que os níveis de TcCPX aumentam (FINZI et al., 2004). 


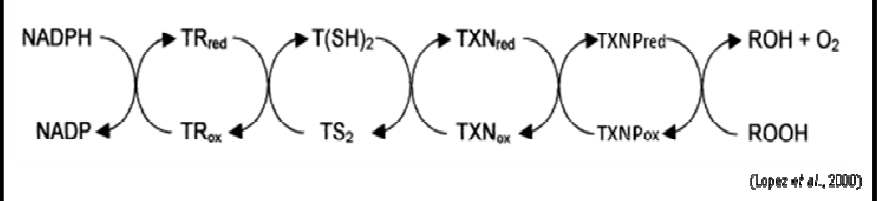

Figura 4. Via da Tripanotiona para detoxificação de $\mathrm{H}_{2} \mathrm{O}_{2}$ em tripanossomatídeos.TR, Tripanotiona redutase; $\mathrm{T}(\mathrm{SH})_{2} / \mathrm{TS}_{2}$, tripanotiona; TXN, triparedoxina; TXNP, triparedoxina peroxidase.

FONTE: Modificado de Lopez et al., 2000.

\subsection{A MITOCÔNDRIA: ESTRUTURA E FUNÇÃO}

Os protozoários flagelados da ordem Kinetoplastida apresentam uma mitocôndria única, multilobulada, que ocupa aproximadamente $12 \%$ do volume celular (PAULIN et al., 1975). A complexidade ultraestrutural e algumas características básicas dos processos bioenergéticos que nela ocorrem são até agora pouco conhecidos. Estes estudos são dificultados pela impossibilidade da obtenção de mitocôndrias intactas, após rompimento das células. De fato, é difícil evitar a alteração da estrutura mitocondrial durante a ruptura dos parasitas pelo tamanho desta organela e pela presença de microtúbulos aderidos do lado interno da membrana plasmática (DAS, 1993). Para contornar este problema, as funções mitocondriais de protozoários flagelados têm sido determinadas em células permeabilizadas com digitonina, um glicosídeo esteróide com características gerais de detergente (VERCESI et al., 1991).

As características da mitocôndria da maior parte dos eucariotos descritas a seguir estão amplamente estabelecidas. Nestes organismos, a mitocôndria está rodeada por uma dupla membrana que envolve a matriz mitocondrial. A membrana externa encontra-se em contato com o citoplasma e é bastante permeável a várias classes de moléculas. A membrana interna, impermeável, é caracterizada por invaginações denominadas cristas, que penetram na matriz mitocondrial. Entre a membrana interna e a externa encontra-se o espaço intermembranar.

Na membrana mitocondrial interna localiza-se a cadeia respiratória ou cadeia de transporte de elétrons, formada por uma série de transportadores que 
experimentam trocas reversíveis em seu estado redóx. São transportadores de elétrons a ubiquinona, nucleotídios como o $\mathrm{NADH}$; estruturas protéicas, como as flavoproteínas, as ferro-sulfoproteínas e os citocromos. Os transportadores estão organizados em quatro complexos respiratórios: Complexo I (NADH:coenzima Qoxidoredutase); Complexo II (succinato:coenzima Q-oxidoredutase); Complexo III (Coenzima Q: citocromo c-oxidoredutase) e Complexo IV (citocromo c-oxidase) (ver esquema na Figura 5).

Os elétrons presentes no NADH são transferidos para o complexo I, que está associado a uma molécula de Flavina Mononucleotídio (FMN), capaz de receber dois prótons e dois elétrons sendo reduzida à forma $\mathrm{FMNH}_{2}$; do complexo I os elétrons passam para a coenzima $\mathrm{Q}$, depois para o complexo III, citocromo $c$, complexo IV e finalmente para o oxigênio. Os prótons e elétrons presentes no succinato são transferidos ao complexo II através de $F A D$ que se reduz a $\mathrm{FADH}_{2} \mathrm{e}$ desta para a coenzima $Q$. Deste ponto em adiante, seguem o caminho comum: complexo III, citocromo $c$, complexo IV e oxigênio.

A coenzima $Q$ ou ubiquinona ( $C o Q$ ou $Q$ ) é uma quinona que apresenta uma longa cadeia lateral composta de unidades isoprênicas, conferindo-lhe características hidrofóbicas, que permitem sua mobilidade na fase lipídica da membrana. A coenzima $Q$ recebe os prótons e elétrons, passando à forma reduzida, $\mathrm{QH}_{2}$; os elétrons são transferidos um a um para o citocromo $c$, com a formação intermediária de semiquinona, $\mathrm{QH}^{\circ}$. A forma mais comum de CoQ encontrada nos organismos superiores apresenta 10 unidades isoprênicas (CoQ-10), no entanto, em T. cruzi, assim como em T. brucei e L. major, a CoQ apresenta 9 unidades e é denominada CoQ-9 (FERELLA et al., 2006).

O citocromo c é uma proteína periférica de membrana, ligada frouxamente à superfície externa da membrana mitocondrial interna, o que lhe permite cumprir sua função na cadeia de transporte de elétrons, qual seja, a de conectar o complexo III, do qual recebe elétrons, ao complexo IV, ao qual doa elétrons. 


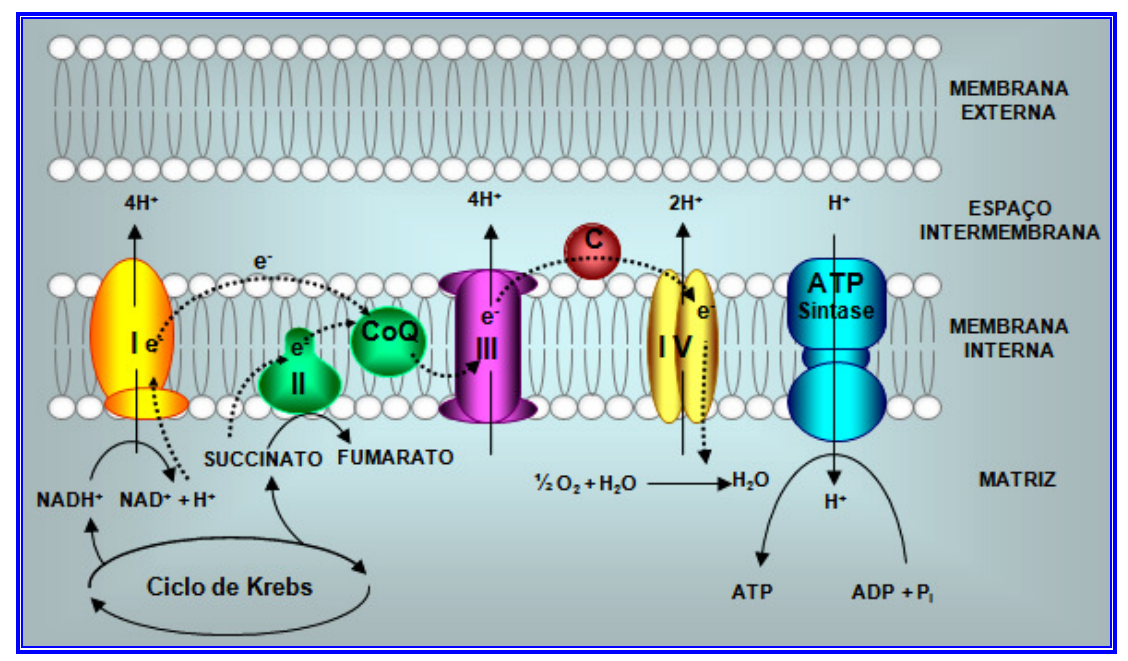

Figura 5. Esquema da cadeia de transporte de elétrons e ATP sintase localizadas na membrana interna da mitocôndria.

FONTE: Modificado de Voet e Voet (2006).

O complexo I, também denominado NADH:ubiquinona oxidoredutase ou NADH-desidrogenase (denominação que utilizaremos nesta tese), catalisa a transferência de dois elétrons do NADH para a coenzima $Q$, através de uma série de centros redóx que incluem FMN e vários grupos ferro-enxofre. Acoplados na transferência de elétrons, quatro prótons são vetorialmente translocados através da membrana interna mitocondrial para o estabelecimento de um gradiente eletroquímico usado para a síntese de ATP.

O complexo I tem sido caracterizado em diferentes organismos, apresentando uma estrutura em forma de L, com um domínio periférico hidrofílico que contém o sítio de união ao NADH, a flavina mononucleotídio (FMN) e os grupos ferro-enxofre (Fe-S) e um longo domínio transmembrana com aproximadamente 60 hélices (YAGI e MATSUNO-YAGI, 2003). A composição do complexo I é variável em diferentes organismos: em E. coli e Paracoccus denitrificans apresenta 13 e 14 subunidades protéicas, respectivamente (YAGI et al., 1998), em Neurospora crassa, 39 subunidades (VIDEIRA e DUARTE, 2002), em Bos taurus, 46 subunidades (HIRST et al., 2003; CARROL et al., 2003), 42 subunidades em Arabidopsis thaliana e Oryza sativa, 42 ou 43 em Chlamydomonas reinharddtii (CARDOL et al., 2004), 37 em 
Yarrowia lipolytica (ABDRAKHMANOVA et al., 2004) e 14 em Thermus thermophilus (SAZANOV e HINCHLIFFE, 2006).

A existência do complexo I em tripanossomatídeos e espécies relacionadas é matéria de extenso debate. A ausência de complexo I funcional nestes organismos foi originalmente sugerida para T. brucei (HILL e CROSS, 1973), posteriormente, para as formas de cultivo de T. cruzi (DENICOLA-SEOANE et al., 1992), cepas de Crithidia fasciculata cultivadas em laboratório (SLOOF et al.,1994) e Leishmania tarentolae (SPEIJER et al., 1997). A não funcionalidade do complexo I se baseia nas seguintes observações: (i) a oxidação de NADH é insensível a rotenona; (ii) nenhum substrato dependente de NADH é capaz de promover a fosforilação de ADP em formas procíclicas de $T$. brucei permeabilizadas com digitonina; e (iii) a redução do citocromo c por NADH ou por substratos dependentes de NADH é insensível a antimicina $A$, indicando que os elétrons do $\mathrm{NADH}$ não alcançam o citocromo c via complexo III (TURRENS, 1989). Turrens (2004) propõe que em tripanossomatídeos o complexo I estaria ausente ou atuaria numa via inteiramente diferente a qual ainda não foi definida.

Por outro lado, outras evidências apóiam a existência do complexo I em tripanossomatídeos: (i) em $T$. brucei os mRNAs de subunidades putativas codificadas no genoma mitocondrial sofrem edição regulada em estágios onde sua presença pode ser apropriada (KOSLOWSKY et al., 1990); (ii) genes homólogos de várias subunidades codificadas no núcleo estão presentes em $T$. cruzi, $T$. brucei e $L$. tarentolae (PETERSON et al., 1993); (iii) anticorpos contra subunidades do complexo I de outros organismos detectam homólogos putativos em western blots de lisados mitocondriais de $T$. brucei (BEATTIE e HOWTON, 1996) e P. serpens (GONZALES-HALPHEN e MASLOV, 2004); (iv) em lisados mitocondriais de $T$. brucei foi detectada atividade de NADH desidrogenase (HORVÁTH et al., 2005).

A subunidade 7 (ND7) da NADH desidrogenase mitocondrial foi reportada inicialmente por Koslowsky et al. (1990) em T. brucei como uma proteína homóloga às de $C$. fasciculata e $L$. tarentolae, altamente homóloga à subunidade de $49 \mathrm{kDa}$ da $\mathrm{NADH}$ desidrogenase de bovinos, à subunidade NDUFS2 humana e Nqo4 de Thermus thermophilus. A subunidade de $49 \mathrm{kDa}$ está localizada no módulo $\mathrm{Q}$ do braço periférico do complexo I, que se projeta para a matriz mitocondrial, que aceita 
elétrons dos grupos ferro-enxofre do módulo $\mathrm{N}$ e transfere estes para ubiquinona (BRANDT, 2006).

As seqüências de aminoácidos de subunidades do complexo I de bactérias e de alguns eucariotos, presentes no banco SwissProt (site: http//www.expasi.ch), foram usadas para uma busca de similaridade (BLASTP) de proteínas homólogas em T. brucei (TriTryp protein-sequence database). Foram identificados 19 polipeptídios: 7 subunidades codificadas no genoma mitocondrial (ND1, CR5/ND3, ND4, ND5, ND7, ND8, ND9) e as restantes (ACP, NB4M, NB6M, N12M, N18M, NUAM, NUBM, NUEM, NUHM, NUKM, PL2, PL6) no DNA nuclear (OPPERDOES e MICHELS, 2008). Com base nestes dados, a massa do complexo I de T. brucei foi estimada em 661 kDa. A estrutura do complexo I é representada na Figura 6.

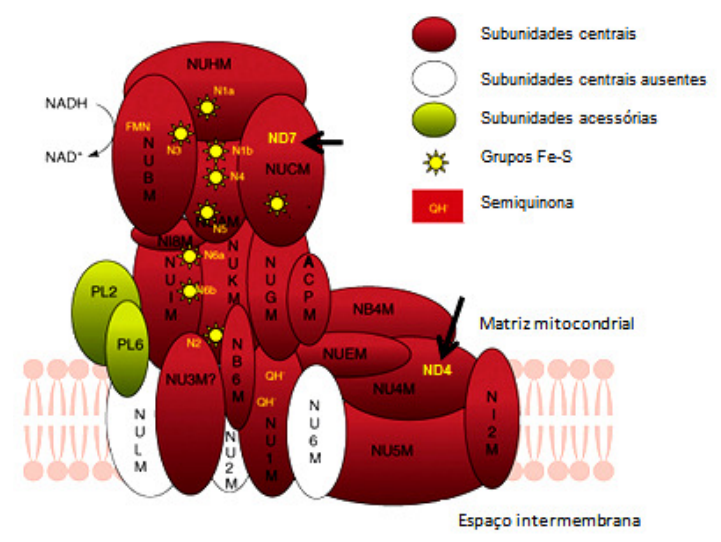

Figura 6. Representação esquemática do complexo I de T. brucei. As setas indicam a localização das subunidades ND4 e ND7, tratadas nesta tese.

FONTE: Modificado de Opperdoes e Michels (2008).

O funcionamento da cadeia de transporte de elétrons de tripanossomas africanos e americanos parece ser diferente de sua contrapartida nas células de mamíferos. De fato, estudos em que foram utilizados inibidores específicos sugerem que os elétrons do NADH não alcançam o citocromo $c$ via complexo III, uma vez que esta atividade não é inibida por antimicina $A$, inibidor clássico de complexo III (TURRENS, 1989; DENICOLA-SEOANE et al., 1992). 
Vários estudos mostram que a cadeia de transporte de elétrons mitocondrial dos Kinetoplastida utiliza quantidades significativas de succinato como doador primário de elétrons (TURRENS, 1989; DENICOLA-SEOANE 1992). De fato, inibidores específicos da succinato desidrogenase (complexo II) inibem o consumo de oxigênio (HERNANDEZ e TURRENS, 1998; COUSTOU et al., 2008).

Fang et al., (2001) isolaram e caracterizaram o complexo I de formas procíclicas de $T$. brucei. Este complexo apresentou sensibilidade a rotenona, piericidina $A$ e capsaicina, inibidores específicos do complexo I. O mesmo grupo (FANG e BEATTIE, 2003) isolou e caracterizou outra atividade de NADH desidrogenase, esta, insensível a rotenona, que foi denominada NADH desidrogenase alternativa (ver Figura 3, enzima 46). Esta atividade, localizada na membrana interna mitocondrial de formas procíclicas de T. brucei, tem FMN como co-fator e transfere elétrons do FMN para vários aceptores, incluindo o oxigênio e a ubiquinona O. Esta atividade pode funcionar como complemento do complexo I, mediando a transferência de elétrons para a cadeia respiratória. Realizamos uma busca de similaridade no genoma de T. cruzi, utilizando o programa BLASTN e como entrada (query) a seqüência de uma NADH desidrogenase alternativa de T. brucei (GenBank: AY125472). Identificamos um mRNA (GenBank: XM807104.1) que apresenta $\sim 70 \%$ de similaridade.

Defeitos no complexo I de respiração são muito comuns em humanos que apresentam alteração de processos de geração de energia. Estes incluem redução na atividade do complexo I e/ou defeitos na sua montagem e/ou sua associação com a geração de EROs. EROs têm sido implicadas em doenças neurodegenerativas como doença de Parkinson, Alzheimer e esclerose múltipla, assim como envelhecimento e apoptose (LAZAROU et al., 2007). Outras patologias são atribuídas a deficiências no complexo I, como Síndrome Infantil de Leigh, LHON (Leber Hereditary Optic Neuropathy) e MELAS (Mitochondrial Encephalomyopathy with Lactic Acidosis and Stroke-like episodes) (MALFATTI et al., 2007).

Em outros organismos, como Zea maiz, uma deleção no gene $N D 4$, que codifica a subunidade 4 do complexo I, impede a montagem do complexo inteiro, acarretando um baixo crescimento da planta, perda foliar e pouca produção de grãos (YAMATO et al., 1999). Em Nicotiana sylvestris, uma deleção no gene nd7 promove 
redução na respiração do vegetal e a não montagem do complexo I, o que origina plantas muito frágeis (PINEAU et al., 2005; CARDOL et al., 2006).

Kashani-Poor et al. (2001) introduziram uma série de mutações no gene que codifica a proteína de $49 \mathrm{kDa}$ de $Y$. lipolytica, homológa à subunidade ND7 de $T$. brucei, para identificar a importância funcional desta no complexo I. Concluíram que nenhuma das mutações afeta a montagem do complexo I, mas todas diminuem ou eliminam a atividade de ubiquinona redutase.

\subsection{GENOMA MITOCONDRIAL EM TRIPANOSSOMATÍDEOS}

Nos tripanossomatídeos, o genoma mitocondrial está localizado numa estrutura em forma de disco, designada cinetoplasto, encontrada junto à base do flagelo. O DNA do cinetoplasto (kDNA) tem uma organização bastante peculiar, formada por moléculas circulares denominadas maxicírculos e minicírculos. Os maxicírculos, representados por poucas dezenas de unidades, são o equivalente funcional do DNA mitocondrial de outros eucariotos, e codificam proteínas e RNAs mitocondriais típicos. Os vários milhares de minicírculos codificam RNAs guias que atuam no processo de edição dos transcritos dos genes do maxicírculo (SHLOMAI, 2004).

Todos os minicírculos e maxicírculos estão concatenados formando uma rede gigante de DNA. Até 2005, estavam disponíveis as seqüências completas dos genes dos maxicírculos das espécies: T. brucei, L. tarentolae e C. fasciculata. (Detalhes no site: http://dna.kdna.ucla.edu/trypanosome/files/tbmaxi.html). Para T. cruzi, apenas uma seqüência de 5.736 nt estava descrita (OCHS et al., 1996). Recentemente, Westenberger et al. (2006) reportaram a seqüência consenso completa dos maxicírculos das cepas CL Brener (DTU Ile) e Esmeraldo (DTU Illb). Concluiu-se que em $T$. cruzi as regiões codificadoras são sintênicas com os maxicírculos de $T$. brucei e L. tarentolae. Os três genomas mitocondriais contêm 18 genes codificadores de proteínas e de dois rRNAs. Na Figura 7 mostra-se a distribuição dos genes na região codificadora do maxicírculo e indica-se a posição dos genes que codificam as subunidades 4 e 7 da NADH desidrogenase (ND4 e ND7) e a subunidade III da citocromo oxidase ou complexo IV (COIII). 
O tamanho dos maxicírculos é de aproximadamente $22 \mathrm{~kb}$ na cepa CL Brener e $28 \mathrm{~kb}$ na cepa Esmeraldo. A diferença de tamanho deriva de diferenças na região não codificadora, que contém uma região variável e uma região com repetições seriadas (WESTENBERGER et al., 2006) (ver Figura 7).

A região codificadora é comparável em tamanho nas duas cepas, no entanto, existem algumas diferenças. A diferença mais marcante refere-se à presença de uma deleção de 236 nucleotídios na cepa Esmeraldo em relação a CL Brener, resultando em extremidades 5' truncadas nos genes que codificam a região 4 rica em C (CR4) e a subunidade 4 da NADH desidrogenase (ND4) (WESTENBERGER et al., 2006). Os dois genes são transcritos em sentidos opostos (ver Figura 7) e a deleção elimina os códons de iniciação de ambos. Como efeitos decorrentes, a deleção também eliminaria o primeiro domínio transmembrana de ND4 e de CR4, cuja função não é conhecida.

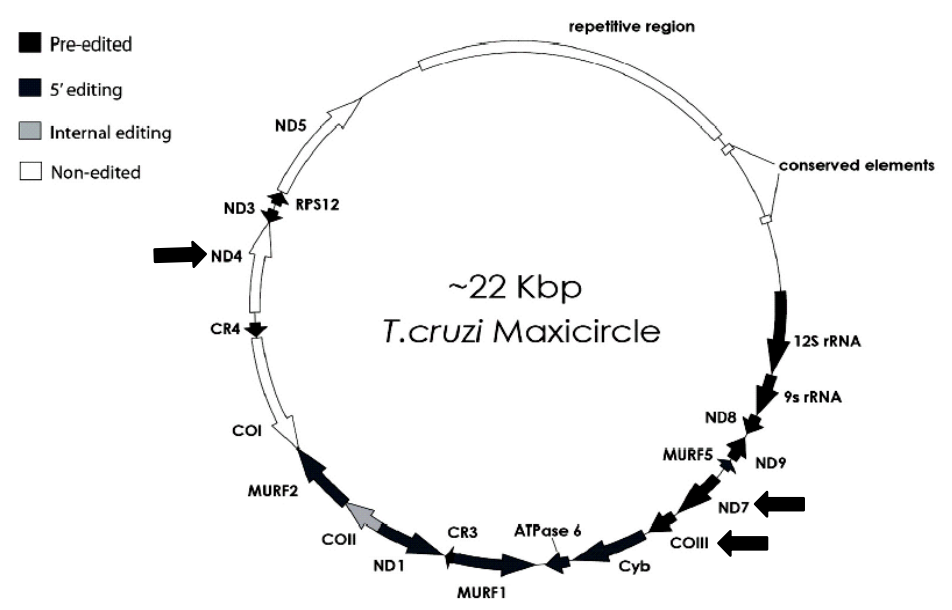

Figura 7. Diagrama do maxicírculo de $T$. cruzi. As setas no círculo indicam o sentido da transcrição. As setas externas indicam a posição dos genes ND4, ND7 e COIII.

FONTE: Westenberger et al. (2006). 


\subsection{CONTROLE DA EXPRESSÃO GÊNICA EM TRIPANOSSOMATÍDEOS}

Os mecanismos de controle da expressão gênica em tripanossomas apresentam características particulares, que incluem: (i) transcrição policistrônica; (ii) adição por trans-splicing de 39 nucleotídios (Spliced leader, SL) na extremidade 5' de todos os RNAs mensageiros; (iii) edição intensa de transcritos mitocondriais; (iv) transcrição de genes codificadores de proteínas pela RNA polimerase I (TEIXEIRA e DAROCHA, 2003).

Acreditava-se que os tripanossomas careciam da maquinaria para realizar cissplicing, com base na observação de que seus genes não contêm íntrons e que não possuem U1-snRNA, necessário para este processo. No entanto, Mair et al. (2000) descreveram que os genes codificadores da poli (A) polimerase (PAP) em T. cruzi e T. brucei estão interrompidos por seqüências intrônicas de 653 e 302 pb, respectivamente, localizados em posições idênticas em ambos os organismos e que seguem a norma GT/AG para cis-splicing de íntrons. Por outro lado, chama a atenção o fato de não terem sido encontrados íntrons em outras classes de genes.

Outro aspecto digno de nota se refere ao processamento dos transcritos policistrônicos para gerar mRNAs maduros. O processamento ocorre pela adição concomitante da cauda de poli-A na extremidade 3' do mRNA e do SL de 39 nucleotídios na extremidade 5' do mRNA subseqüente. Neste processo, a região intergênica é removida. O SL apresenta a estrutura cap metilada, que é adicionada em uma reação de trans-esterificação que requer um dinucleotídio conservado AG no sitio de adição. Estes processos parecem ser dependentes do reconhecimento de uma seqüência de polipirimidina presente na região intergênica que atua como elemento bifuncional afetando o processamento do RNA em ambos os extremos (D'ORSO e FRASCH, 2001).

Nos Kinetoplastida o controle da expressão gênica ocorre principalmente na etapa pós-transcricional. Neste controle, as regiões 5' e 3' não traduzidas (UTRs) são responsáveis por mecanismos de estabilização ou desestabilização dos transcritos. Foram descritos vários elementos que atuam neste processo. Por exemplo, elementos ARE (ricos em AU) e GRE (ricos em G). Estes são ciselementos funcionais que regulam a expressão da mucina durante o ciclo de vida de T. cruzi (D'ORSO e FRASCH, 2001). 
A tecnologia de microarranjos de DNA permite examinar simultaneamente a expressão diferencial de milhares de genes em organismos e tecidos. Para T. cruzi, até 2003, um único trabalho havia sido publicado onde microarranjos de DNA foram utilizados para identificar a expressão diferencial de genes durante a transformação de formas tripomastigotas em amastigotas (MINNING et al., 2003). Uma vez que isolados de $T$. cruzi apresentam elevada diversidade genética, nosso laboratório avaliou se microarranjos de DNA contendo predominantemente ESTs (Etiquetas de Seqüências Transcritas) de CL Brener podiam ser usados para estudos de genômica comparativa e para investigar a expressão diferencial de genes em cepas do parasita. Para esta finalidade, foi construído um protótipo de lâmina de microarranjo contendo 710 ESTs e 20 genes bem caracterizados de diversas cepas de T. cruzi (BAPTISTA et al., 2004). O microarranjo foi hibridizado com DNA ou cDNA de dois pares de cepas: CL Brener (T. cruzi II) e Silvio X10 cl1 ( T. cruzi I) e duas cepas de T. cruzi II isoladas, respectivamente, de um indivíduo assintomático e de um paciente com manifestações cardíacas e digestivas. Os resultados deste trabalho mostraram a utilidade dos microarranjos para estudos comparativos entre cepas e confirmaram que $T$. cruzi possui um grau elevado de regulação pós-transcricional para controlar a abundância de RNA (BAPTISTA et al., 2004).

Posteriormente, com uma versão modificada de microarranjos de DNA, nosso laboratório analisou a transcrição diferencial de genes em três isolados de pacientes com a forma indeterminada e três isolados de pacientes com a forma cardíaca da doença de Chagas (BAPTISTA et al., 2006). Foi observado que o transcrito da subunidade 7 da NADH desidrogenase mitocondrial (ND7) era cerca de 30 vezes mais abundante nas cepas de cardiopatas em relação a cepas de assintomáticos. Análises por Southern blot indicaram diferenças na estrutura do gene ND7 nos dois grupos de cepas (BAPTISTA et al., 2006). 


\section{JUSTIFICATIVA}

Quando chegamos ao laboratório no IQ-USP em 2005, para iniciar o programa de doutoramento, Cassio Baptista, então estudante de doutorado, empregando a tecnologia de microarranjos de DNA, havia observado que o gene que codifica a subunidade 7 do complexo I da cadeia de transporte de elétrons era transcrito diferencialmente em isolados de pacientes com CCC em relação a isolados de ASS (dados publicados posteriormente em Baptista et al., 2006). Esta observação sugeria que ND7 poderia ser um alvo interessante para diferenciar as duas classes de isolados, com possível aplicação no diagnóstico da cepa infectante. Desta forma, um objetivo imediato a ser perseguido foi analisar a estrutura do gene ND7 nos isolados de T. cruzi e validar a hipótese de que este gene era capaz de diferenciar isolados de pacientes com CCC de isolados de ASS.

Tendo em vista que o complexo I é o local de entrada de elétrons do NADH, a avaliação da função mitocondrial nas duas classes de isolados foi o segundo objetivo do projeto. Este estudo poderia contribuir para o entendimento da funcionalidade do complexo I em tripanossomatídeos, tema bastante controverso, conforme comentado acima.

No decorrer do trabalho, Margoth Moreno, estudante de doutorado, verificou diferenças na abundância de transcritos de alguns componentes do Sistema da Tripanotiona em duas cepas humanas. Uma vez que este sistema está envolvido na detoxificação de EROS, também nos propusemos avaliar a sensibilidade de isolados humanos a peróxido de hidrogênio e os níveis dos mRNAs de alguns genes cujo produto poderia atuar na proteção contra EROs. 


\section{OBJETIVOS}

\section{OBJETIVO GERAL}

O objetivo geral do estudo foi caracterizar a estrutura do gene da subunidade $7 \mathrm{da}$ $\mathrm{NADH}$ desidrogenase (ND7) em isolados humanos e a atividade funcional do Complexo I mitocondrial em T. cruzi.

\section{OBJETIVOS ESPECÍFICOS}

- Caracterização da estrutura do gene ND7 de isolados de pacientes ASS e com CCC.

- Verificação da aplicabilidade do gene ND7 como alvo para o diagnóstico diferencial da cepa infectante.

- Determinação de alguns parâmetros funcionais da mitocôndria nas duas classes de isolados.

- Verificação da sensibilidade de isolados humanos a peróxido de hidrogênio $\left(\mathrm{H}_{2} \mathrm{O}_{2}\right)$.

- Avaliação dos níveis de mRNA de alguns genes envolvidos na defesa contra EROs. 


\section{MATERIAL E MÉTODOS}

\subsection{CEPAS E ISOLADOS DE T. cruzi}

As características das cepas de referência utilizadas neste estudo estão descritas no item Resultados. Estas cepas estavam criopreservadas em nosso laboratório (IQ-USP). Formas epimastigotas foram cultivadas em meio LIT suplementado com 10\% de Soro Fetal Bovino (SFB) (CAMARGO et al.,1964) a 28 ${ }^{\circ} \mathrm{C}$, sem agitação. Os isolados humanos foram obtidos por hemocultura, por nossos colaboradores Profs. Drs. E. Chiari, L. M. Galvão e E. Gontijo (UFMG), conforme descrito anteriormente (CHIARI et al., 1998). Os parasitas foram mantidos em meio LIT-SFB por pouco tempo para minimizar a possível seleção de sub-populações e foram criopreservados em nitrogênio líquido.

NOTA: As características dos pacientes a partir dos quais derivaram os isolados utilizados neste estudo foram determinadas pelos pesquisadores acima mencionados e são descritas em Resultados e no manuscrito anexo.

\subsection{GENOTIPAGEM DAS CEPAS}

As cepas foram caracterizadas como pertencentes aos grupos $T$. cruzi I, $T$. cruzi II e rDNA $1 / 2$ pela amplificação do domínio divergente D7 do rDNA 24S $\alpha$ (SOUTO et al., 1996). Os isolados de Zimodema 3 foram caracterizados como pertencentes aos sub-grupos Z3-A e Z3-B utilizando a metodologia descrita por Mendonça et al. (2002).

\subsection{EXTRAÇÃO E PURIFICAÇÃO DE DNA}

O DNA total dos parasitas foi extraído pelo método proposto por Macedo et al. (1992), que compreende: digestão das amostras com proteinase K, extrações com fenol, fenol-clorofórmio-álcool isoamílico, clorofórmio-álcool isoamílico, precipitação com etanol, digestão com RNase A, seguida por nova extração com fenol- 
clorofórmio-álcool isoamílico e precipitação com etanol. O DNA foi ressuspenso em TE $(\mathrm{pH} 8,0)$ e sua concentração foi estimada por espectrofotometria a $260 \mathrm{~nm}$.

\subsection{AMPLIFICAÇÃO DE SEQÜÊNCIAS DE GENES DE MAXICÍRCULOS}

\subsubsection{Subunidade 7 da NADH desidrogenase (ND7)}

Para a amplificação do gene que codifica ND7, foi utilizada a seguinte mistura de reação $(25 \mu \mathrm{L})$ : 100 ng de DNA; 1 unidade de Taq DNA polimerase (Biolase, Sinapse Biotecnologia, São Paulo, Brasil); $2,5 \mu \mathrm{L}$ de tampão 10x (160 mM $\left(\mathrm{NH}_{4}\right)_{2} \mathrm{SO}_{4}, 670 \mathrm{mM}$ Tris-HCl $(\mathrm{pH} 8,8), 0,1 \%$ Tween-20; $3 \mathrm{mM} \mathrm{MgCl}$ ); 0,2 mM de cada dNTP e 1mM dos oligonucleotídeos TcMaxi ND7-F (5`-AAG AAA AGA GGG GAC AAA CG-3`) e TcMaxi ND7-R (5`AAA AAT CCC CTT CCA AAA GC-3`), desenhados sobre as regiões que flanqueiam o gene ND7 da cepa CL Brener (GenBank: DQ343645). As amostras foram desnaturadas 2 minutos a $93{ }^{\circ} \mathrm{C}$, e a amplificação foi realizada em 35 ciclos de três temperaturas: 30 segundos de desnaturação a $93{ }^{\circ} \mathrm{C}, 30$ segundos para anelamento dos iniciadores a $60{ }^{\circ} \mathrm{C}, 1$ minuto de extensão a $72{ }^{\circ} \mathrm{C}$ e uma extensão final de 10 minutos. Os produtos de amplificação foram visualizados em gel de agarose $0,8 \%$ corado com brometo de etídio.

\subsubsection{Subunidade III da citocromo oxidase (COIII)}

Para a amplificação do gene que codifica COIII foi utilizada a seguinte mistura de reação (25 $\mu \mathrm{L}): 100$ ng de DNA; 1 unidade de Taq DNA polimerase (Biolase); 2,5 $\mu \mathrm{L}$ de tampão 10x descrito acima; 0,2 $\mathrm{mM}$ de cada dNTP e $1 \mathrm{mM}$ dos oligonucleotídeos CO1 (5'-CGG AGC ATT TTT ATG GAG AGG-3') e CO2 (5'-GAA GAC CCT TCC TCT TTT CTC C-3') desenhados sobre a região que flanqueia a seqüência COIII (GenBank: DQ343645). As amostras foram desnaturadas 4 minutos a $94{ }^{\circ} \mathrm{C}$ e a amplificação foi realizada em 35 ciclos de três temperaturas: um minuto a $94{ }^{\circ} \mathrm{C}$, um minuto a $57^{\circ} \mathrm{C}$ para anelamento dos iniciadores, um minuto de extensão 
a $72{ }^{\circ} \mathrm{C}$ e uma extensão final a $72{ }^{\circ} \mathrm{C}$ por 10 minutos. Os produtos de PCR foram visualizados em gel de agarose $0,8 \%$ corado com brometo de etídio.

\subsubsection{Subunidade 4 da NADH desidrogenase mitocondrial (ND4)}

Para a amplificação do gene que codifica ND4 foi utilizada a seguinte mistura de reação (25 $\mu \mathrm{L}): 100$ ng de DNA; 1 unidade de Taq DNA polimerase (Biolase); 2,5 $\mu \mathrm{L}$ de tampão 10x descrito acima; 0,2 $\mathrm{mM}$ de cada dNTP e $1 \mathrm{mM}$ dos oligonucleotídeos ND4.For (5'-AAA CTC TAT CTT TCG AAA ACC C-3`) e ND4.Rev (5'-GGG AAA AAT AGA CTT TCA AAA AGT ATC-3`) desenhados sobre os genes CR4 e ND4 baseados na seqüência de CL Brener (GenBank: DQ343645). As amostras foram desnaturadas 2 minutos a $94^{\circ} \mathrm{C}$ e a amplificação foi realizada em 30 ciclos de três temperaturas: um minuto a $94{ }^{\circ} \mathrm{C}$; um minuto a $55^{\circ} \mathrm{C}$ para anelamento dos iniciadores; um minuto de extensão a $72{ }^{\circ} \mathrm{C}$ e uma extensão final a $72{ }^{\circ} \mathrm{C}$ por 10 minutos. Os produtos de PCR foram visualizados em gel de agarose $0,8 \%$ corado com brometo de etídio.

\subsection{CLONAGEM E SEQÜENCIAMENTO DE PRODUTOS DE AMPLIFICAÇÃO}

Os produtos de amplificação de ND7 foram purificados do gel de agarose utilizando o PureLink ${ }^{T M}$ Gel Purification Kit (Invitrogen LTDA, São Paulo, S.P, Brasil) e quantificados por espectrofotometria a $260 \mathrm{~nm}$. Em seguida, foram clonados com o sistema TOPO-TA cloning Kit (Invitrogen) e os plasmídeos foram transformados em E. coli quimiocompetentes (One Shot TOP-10) seguindo-se as instruções do fabricante. O DNA dos plasmídeos recombinantes foi obtido utilizando-se procedimentos convencionais baseados no método de lise alcalina (BIRNBOIM e DOLY, 1979). Os insertos clonados foram confirmados por PCR utilizando-se os iniciadores M13F/M13R e TcMaxi ND7-F/ TcMaxi ND7-R.

A reação de seqüenciamento das duas fitas do inserto do DNA plasmidial foi feita com Big Dye Terminator v.3.1 (Applied Biosystems, São Paulo, Brasil) conforme protocolo do fabricante e usando iniciadores específicos para o plasmídeo. Foi utilizado o seqüenciador $\mathrm{ABI}$-PRISM ${ }^{\circledR} 3100$ (IQ-USP). 
As análises das seqüências forward e reverse para obtenção da seqüência consenso foram feitas pelo programa DNAStar SeqMan (DNAStar Inc.). As seqüências foram alinhadas e ajustadas usando o programa GeneDoc 2.6.002 (NICHOLAS et al., 1997). As seqüências foram submetidas a análises de similaridade e alinhamentos com as seqüências depositadas no GenBank mediante o programa BLASTN acessado através do site http:www.ncbi.nlm.nih.gov.

\subsection{DETERMINAÇÃO DE PARÂMETROS FUNCIONAIS DA MITOCÔNDRIA}

\subsubsection{Cultura e obtenção de parasitas}

Formas epimastigotas, cultivadas em meio LIT-SFB, foram coletadas por centrifugação em fase exponencial de crescimento $\left(\sim 7 \times 10^{7}\right.$ parasitas $\left./ \mathrm{mL}\right)$ e lavadas duas vezes com PBS. A densidade dos parasitas foi determinada por contagem em câmara de Neubauer e ajustada para $\sim 7 \times 10^{7}$ parasitas $/ \mathrm{mL}$. A concentração de proteína foi determinada pelo método de Bradford (BRADFORD, 1976) com leitura de absorbância a $595 \mathrm{~nm}$ utilizando um espectrofotômetro Gene Quant (Amersham Biosciences) e soroalbumina bovina como padrão.

\subsubsection{Determinação da viabilidade dos parasitas no meio de reação}

O meio de reação foi preparado de acordo com Docampo e Vercesi (1989) e continha sacarose $125 \mathrm{mM}, \mathrm{KCl} 65 \mathrm{mM}$, HEPES $10 \mathrm{mM}(\mathrm{pH} 7,0), \mathrm{MgCl}_{2} 2 \mathrm{mM}$, $\mathrm{KH}_{2} \mathrm{PO}_{4} 2 \mathrm{mM}$ e EGTA $0,5 \mathrm{mM}$. A viabilidade dos parasitas foi monitorada ao longo do tempo de incubação a $28{ }^{\circ} \mathrm{C}$ pelo método do azul de tripan (PHILIPS, 1973). $\mathrm{O}$ corante foi preparado na concentração de $0,4 \%(p / v)$ em PBS e foi utilizado na proporção 1:10 (v/v) (corante:amostra). Os parasitas foram contados em câmara de Neubauer. A porcentagem de viabilidade foi calculada conforme a equação $\mathrm{CV}(\%)=$ $100(\mathrm{NC} / \mathrm{NC}+\mathrm{C})$, onde $\mathrm{CV}=$ células viáveis; $\mathrm{NC}=$ células não coradas e $\mathrm{C}=$ células coradas com azul de tripan. 


\subsubsection{Determinação da concentração de digitonina para a permeabilização dos parasitas}

A quantidade de digitonina requerida para uma permeabilização apropriada das células foi determinada mediante a adição de concentrações crescentes do reagente e medidas do controle de respiração em presença de succinato $5 \mathrm{mM}$ como substrato respiratório e $200 \mu \mathrm{M}$ de ADP (TURRENS, 1989; RODRIGUES et al., 2001).

\subsubsection{Determinação do controle respiratório}

A medida do consumo de oxigênio com substratos respiratórios para os complexos I (piruvato e malato) e II (succinato) em parasitas permeabilizados com digitonina foi realizada com um eletrodo tipo Clark fixado a um oxígrafo Hansa Tech $^{\circledR}$. Uma alíquota da suspensão de epimastigotas foi adicionada ao meio de respiração (volume final $1 \mathrm{~mL}$ ) para uma concentração final de $5 \times 10^{7}$ células $/ \mathrm{mL}$, que equivale a aproximadamente $1 \mathrm{mg} / \mathrm{mL}$ de proteína.

O controle respiratório $(\mathrm{CR})$ foi determinado pela relação entre a velocidade respiratória na presença de ADP ou estado III e a velocidade depois do consumo de ADP ou estado IV (CR = estado III/estado IV) (ESTABROOK, 1967). O valor de estado IV de respiração foi obtido após adição de oligomicina, um inibidor da $F_{1} F_{0}$ ATP sintase, numa concentração final de $1 \mu \mathrm{g} / \mathrm{mL}$ (VERCESI et al., 1991).

\subsubsection{Determinação do controle respiratório com piruvato e malato como substratos para o complexo I}

A capacidade da cadeia respiratória mitocondrial de epimastigotas permeabilizados com digitonina para oxidar NADH através do complexo I foi determinada aplicando-se o protocolo de Duan et al. (2003) com algumas modificações. A mistura de incubação ( $1 \mathrm{~mL}$, volume final) continha: piruvato $5 \mathrm{mM}$; malato $5 \mathrm{mM}$; ADP $200 \mu \mathrm{M}$; oligomicina $1 \mu \mathrm{M}$; CCCP $1 \mu \mathrm{M}$ (Carbonil cianeto 3clorofenilhidrazona); $5 \times 10^{7}$ células $/ \mathrm{mL}$ e digitonina $64 \mu \mathrm{M}$. 


\subsubsection{Determinação do controle respiratório com succinato como substrato para o complexo II}

A mistura de incubação ( $1 \mathrm{~mL}$, volume final) continha: succinato $5 \mathrm{mM}$; ADP $200 \mu \mathrm{M}$; oligomicina $1 \mu \mathrm{M}$; CCCP $1 \mu \mathrm{M} ; 5 \times 10^{7}$ células/mL e digitonina $64 \mu \mathrm{M}$ (RODRIGUES et al., 2001).

\subsubsection{Avaliação da capacidade da cadeia respiratória mitocondrial de epimastigotas para oxidar NADH via complexo I, bloqueando o complexo II com malonato}

Foi seguido o protocolo proposto por Turrens et al. (1989) com algumas modificações. A mistura de incubação (1 mL, volume final) continha: piruvato $5 \mathrm{mM}$; malato 5 mM; malonato 10 mM; ADP $200 \mu \mathrm{M}$; oligomicina $1 \mu \mathrm{M}$; CCCP $1 \mu \mathrm{M}$; 5X107 células/mL e digitonina $64 \mu \mathrm{M}$.

\subsection{MEDIDA DO PERÓXIDO DE HIDROGÊNIO $\left(\mathrm{H}_{2} \mathrm{O}_{2}\right)$ LIBERADO PELA MITOCÔNDRIA}

Epimastigotas em fase exponencial de crescimento foram lavados em PBS e ressuspensos neste tampão. A determinação do peróxido de hidrogênio produzido foi realizada em Fluorímetro Hitachi f-4500 equipado com agitador e cubetas termorreguladas a $28{ }^{\circ} \mathrm{C}$. A mistura de reação (volume final de $2 \mathrm{~mL}$ ) continha: sacarose 125 mM, KCl 65 mM, HEPES 10 mM (pH7,0), $\mathrm{MgCl}_{2} 2 \mathrm{mM}, \mathrm{KH}_{2} \mathrm{PO}_{4} 2 \mathrm{mM}$; EGTA 0,5 mM; digitonina $64 \mu \mathrm{M}$; substratos respiratórios: piruvato $5 \mathrm{mM}$ e malato 5 mM para o complexo I ou succinato $5 \mathrm{mM}$ para o complexo II; ADP $200 \mu \mathrm{M}$, oligomicina $1 \mu \mathrm{M}$ e CCCP $1 \mu \mathrm{M}$. Uma alíquota de suspensão de epimastigotas foi adicionada ao meio para uma concentração de $\sim 5 \times 10^{7}$ células $/ \mathrm{mL}$ (aproximadamente $1 \mathrm{mg}$ de proteína/mL).

Para a determinação da quantidade de $\mathrm{H}_{2} \mathrm{O}_{2}$ liberado, utilizaram-se os protocolos ligeiramente modificados de Mohanty et al. (1997) e Zhou et al. (1997). A reação foi iniciada pela adição de $50 \mu \mathrm{M}$ de Amplex red (10-acetyl-3,7dihydroxyphenoxazine) e $1 \mathrm{U} / \mathrm{mL}$ de HRP (Horseradish peroxidase). Em presença da 
peroxidase, o Amplex red reage com a $\mathrm{H}_{2} \mathrm{O}_{2}$ formada, numa estequiometria 1:1, para gerar um produto de oxidação vermelho-fluorescente denominado resorufina. Esta foi quantificada por absorção e emissão de fluorescência a 563 nm e 587 nm, respectivamente. A concentração de $\mathrm{H}_{2} \mathrm{O}_{2}$ foi determinada usando uma curva de calibração com concentrações conhecidas de resorufina.

\subsection{MONITORAMENTO DOS NÍVEIS DE NAD MITOCONDRIAL EM EPIMASTIGOTAS}

Foi empregado o protocolo descrito por Chance et al. (1959) e revisto por Mayevsky e Rogatsky (2007), utilizando a propriedade de NADH absorver luz num comprimento de onda de 352 nm e emitir luz em 464 nm, monitorando-se assim a abundância relativa de NADH. Foi utilizado antimicina A como inibidor do complexo III, o que resulta num incremento na fluorescência (100\% NADH) e CCCP, um protonóforo desacoplador, que causa a máxima oxidação $\left(100 \% \mathrm{NAD}^{+}\right)$e um decréscimento na fluorescência.

A estimativa da quantidade relativa de NADH foi realizada num Fluorímetro Hitachi f-4500 equipado com agitador e cubetas termorreguladas. As células foram incubadas no mesmo meio de reação usado na determinação de $\mathrm{H}_{2} \mathrm{O}_{2}$ mitocondrial e os mesmos substratos respiratórios. A leitura foi feita em Unidades Arbitrárias de Fluorescência (UAF) e o resultado é expresso como:

$F_{1}$ : fluorescência basal.

$\mathrm{F}_{2}$ : máxima acumulação relativa de $\mathrm{NADH}$ gerada por adição de antimicina $\mathrm{A}$ $(1 \mu \mathrm{g})$

$\mathrm{F}_{3}$ : máxima oxidação $\left(\mathrm{NAD}^{+}\right)$por adição do desacoplador CCCP $(1 \mu \mathrm{M})$.

A acumulação relativa de NAD nas duas cepas foi determinada pela diferença nas leituras de fluorescência assim:

Diferença de NADH: $\quad \Delta \mathrm{F}_{\mathrm{NADH}}=\mathrm{F}_{1}-\mathrm{F}_{3}$

Diferença de $N A D^{+}: \Delta F_{N A D}{ }^{+}=F_{2}-F_{1}$

Diferença Total: $\Delta \mathrm{F}_{\mathrm{T}}=\mathrm{F}_{2}-\mathrm{F}_{3}$ 
Os experimentos foram realizados em triplicatas. A análise estatística dos resultados de comparação da abundância de NADH entre as duas cepas foi realizada com o teste estatístico de $t$-Student com um nível de confiança de $95 \%$. A diferença foi considerada significativa com valor $p<0,05$.

\subsection{SENSIBILIDADE DE EPIMASTIGOTAS A PERÓXIDO DE HIDROGÊNIO EXÓGENO}

Aplicou-se o método descrito por Goyal et al. (1996), ligeiramente modificado. Formas epimastigotas em fase exponencial de crescim $4{ }^{\circ} \mathrm{C}$ em PBS $(\mathrm{pH} 7,4)$ e ressuspensas no mesmo tampão. A concentração dos parasitas foi ajustada para se ter $24 \times 10^{6}$ epimastigotas $/ \mathrm{mL}$ no volume final de reação $(1 \mathrm{~mL})$.

A concentração da solução de $\mathrm{H}_{2} \mathrm{O}_{2}$ a ser adicionada aos parasitas foi determinada antes de cada experimento, por diluição de uma solução estoque e determinação da absorbância a $230 \mathrm{~nm}$ (Coeficiente de extinção $81 \mathrm{M}^{-1} \mathrm{~cm}^{-1}$; PENKETH et al., 1986). A suspensão de parasitas foi exposta a diferentes concentrações de $\mathrm{H}_{2} \mathrm{O}_{2}$ juntamente com um controle negativo sem reagente. Os parasitas foram incubados a $28{ }^{\circ} \mathrm{C}$ durante uma hora e, em seguida, centrifugados a $7000 \mathrm{rpm}$ por $7 \mathrm{~min}$ a $4{ }^{\circ} \mathrm{C}$. O sobrenadante foi descartado e substituído por $1,5 \mathrm{~mL}$ de meio LIT-SFB. Os parasitas foram incubados durante 24 horas a $28^{\circ} \mathrm{C}$. Alíquotas foram retiradas e a concentração de parasitas foi determinada em câmara de Neubauer. A concentração de $\mathrm{H}_{2} \mathrm{O}_{2}$ que inibe a viabilidade dos parasitas em $50 \%$ $\left(\mathrm{Cl}_{50}\right)$ em relação ao controle foi calculada pelo software Origin Pro 7.0 (Original Lab Corp. 2002).

\subsection{AVALIAÇÃO DOS NÍVEIS DE mRNA DE GENES ENVOLVIDOS NO MECANISMO DE DETOXIFICAÇÃO DE EROS EM ISOLADOS HUMANOS POR RT-PCR EM TEMPO REAL}

\subsubsection{Extração de RNA}

RNA total foi extraído pelo método de $\operatorname{TRIZOL}^{\circledR}$ (Invitrogen) e tratado com DNase livre de RNase (PROMEGA), seguindo as recomendações dos fabricantes. Aproximadamente $5 \mu \mathrm{g}$ de RNA foi analisado por eletroforese em gel de agarose 
0.8\% corado com brometo de etídio e fotografado para se ter uma visão da qualidade da amostra. Para verificar a possível presença de DNA contaminante, foi realizada uma PCR convencional com os pares de iniciadores de cada gene (ver Tabela 1).

\subsubsection{Transcrição reversa}

Para a síntese da primeira fita de cDNA, na reação de transcrição reversa (volume final $30 \mu \mathrm{L}$ ) foram utilizados $5 \mu \mathrm{g}$ de RNA total tratado com DNase, 0,5 mM da mistura de dNTPs, 0,5 $\mathrm{gg}$ de hexanucleotídeos randômicos, tampão de primeira fita 1x (Invitrogen), DTT $10 \mathrm{mM}$ e $40 \mathrm{U} / \mu \mathrm{l}$ de RNase-out (Invitrogen). A mistura foi incubada a $42{ }^{\circ} \mathrm{C}$ por dois minutos e posteriormente foram adicionadas $20 \mathrm{U}$ de Transcriptase Reversa Super Script II (Invitrogen) incubando-se a $25{ }^{\circ} \mathrm{C}$ por 10 minutos e $42{ }^{\circ} \mathrm{C}$ por 50 minutos. A reação foi interrompida por aquecimento a $70{ }^{\circ} \mathrm{C}$ por 15 minutos e a amostra foi diluída 4 vezes com água livre de nucleases.

\subsubsection{PCR em tempo real}

A primeira fita de cDNA $(5 \mu \mathrm{L})$ foi usada para a reação de amplificação num termociclador Eppendorf real plex ${ }^{\circledR}$ com iniciadores específicos (Tabela 1). Estes iniciadores foram desenhados sobre a seqüência nucleotídica completa de cada gene em estudo com o auxílio do programa Primer Express (Applied Biosystems) que os desenha com as características necessárias para os experimentos de PCR em tempo real. O tamanho dos fragmentos amplificados foi de $70 \mathrm{pb}$.

Nos ensaios utilizou-se como referência a cepa Berenice 62 por apresentar grande sensibilidade a $\mathrm{H}_{2} \mathrm{O}_{2}$ (ver em Resultados). $\mathrm{O}$ gene que codifica $a$ Gliceraldeído-3-fosfato desidrogenase (GAPDH) foi usado como controle interno ou normalizador da quantidade da amostra por ser um housekeeping gene. Nas reações de amplificação foram utilizados $0,2 \mu \mathrm{M}$ de cada iniciador forward e reverse; SYBR Advantage qPCR Premix 1x, que contém $\mathrm{MgCl}_{2}$, dNTPs, Ampli Taq Gold DNA polimerase, Hot-start Taq antibody, SYBR Green I e tampão; $5 \mu \mathrm{L}$ do DNA alvo (aproximadamente $100 \mathrm{ng}$ ) e água para um volume final de $30 \mu \mathrm{L}$. O perfil de temperatura de amplificação foi de desnaturação a $95^{\circ} \mathrm{C}$ por 10 minutos, seguido de 
40 ciclos de: 15 segundos de desnaturação a $95{ }^{\circ} \mathrm{C}, 15$ segundos de anelamento dos iniciadores a $55^{\circ} \mathrm{C}$ e 20 segundos de extensão a $68^{\circ} \mathrm{C}$.

Tabela 1. Seqüência dos oligonucleotídeos utilizados nos experimentos de PCR em tempo real.

\begin{tabular}{|c|c|c|}
\hline Gene & GenBank & $\begin{array}{c}\text { Seqüência dos oligonucleotídios } \\
5,-3,\end{array}$ \\
\hline $\begin{array}{l}\text { Triparedoxina peroxidase } \\
\text { Citossólica }\end{array}$ & XM_803661.1 & $\begin{array}{l}\text { TCAATGAGACGGCGCTGAT } \\
\text { ACCAGCCACTTGCCCTTGTA }\end{array}$ \\
\hline Tripanotiona sintetase & XM_814378.1 & $\begin{array}{l}\text { TAGCCGATCAGAACCGCTTT } \\
\text { TCAACACATTCCAGCGGAAA }\end{array}$ \\
\hline SOD-A ${ }^{1}$ & $X P \_804176.1$ & $\begin{array}{l}\text { CTGGCAGGGACAACATACGA } \\
\text { CCTTCTTCTCGGCGTCATTT }\end{array}$ \\
\hline SOD-A ${ }^{2}$ & XM_805945.1 & $\begin{array}{l}\text { GGGCCTCTCCGTCTTTCTTC } \\
\text { GTAACGTCCGGCGCATTT }\end{array}$ \\
\hline GAPDH (normalizador) & XM_814806 & $\begin{array}{l}\text { GACGACACGCCCATGTTTG } \\
\text { ACGAGGCGTTGGAGACGAT }\end{array}$ \\
\hline
\end{tabular}

\subsubsection{Análise dos dados}

Cada ensaio foi realizado em triplicata. Os dados foram analisados usando 0 software Realplex (Eppendorf systems ${ }^{\circledR}$ ) e normalizados para os valores de GAPDH. Para cada amostra foi obtido o Ct (Threshold cycle) que é definido como o ciclo onde a fluorescência se encontra estatisticamente acima do background. Foi obtida a média dos Cts das triplicatas e seu desvio padrão.

Uma vez que a expressão do gene é analisada em relação ao controle interno (GAPDH), foi então calculado o $\Delta \mathrm{Ct}$, ou seja, a diferença entre as médias do $\mathrm{Ct}$ de cada amostra e a média do Ct do controle interno (GAPDH).

$$
\Delta \mathrm{Ct}=\mathrm{Ct} \text { amostra }-\mathrm{Ct}_{\text {normalizador }}
$$

Posteriormente, foi calculado o $\Delta \Delta \mathrm{Ct}$ que consiste na diferença do $\Delta \mathrm{Ct}$ de cada amostra em relação ao $\Delta \mathrm{Ct}$ da amostra de referência (cepa Berenice 62). 


$$
\Delta \Delta \mathrm{Ct}=\Delta \mathrm{Ct} \text { amostra }-\Delta \mathrm{Ct} \text { referência }
$$

Os $\Delta \Delta \mathrm{Ct}$ encontrados refletem as diferenças de abundância de produto entre os ciclos, mas não refletem diretamente a diferença de produto entre as amostras. Para calcular a razão relativa da abundância dos transcritos de cada gene em relação à abundância de transcritos na cepa de referência, foi aplicada a fórmula 2 $\Delta \triangle C t$, que parte do princípio de que a cada ciclo da PCR a quantidade de produto dobra, sendo então necessário contemplar que o ganho de cada ciclo (2 vezes) seja elevado à potência do inverso de $\Delta \Delta \mathrm{Ct}$ (PFAFFL, 2001).

$$
\text { razão relativa à amostra de referência }=2^{-\Delta \Delta \mathrm{Ct}}
$$

A análise estatística dos resultados de comparação da abundância de transcritos entre as cepas foi obtida com o programa Origin Pro 7.0 (Original Lab Corp. 2002), através do teste T com variâncias desiguais desconhecidas. 


\section{RESULTADOS}

NOTA: Parte dos Resultados descritos a seguir (items 5.1 - 5.4) estão publicados no artigo anexo (BAPTISTA et al., 2006) e no manuscrito em preparação também anexo (CARRANZA et al.).

\subsection{ESTRUTURA DO GENE ND7}

Para examinar as diferenças na estrutura do gene ND7 entre cepas de $T$. cruzi, foram desenhados iniciadores localizados nos genes MURF5 e COIII que flanqueiam a seqüência ND7 de CL Brener (GeneBank Accession $n^{\circ}$. DQ343645) (ver Figura 10). Para CL Brener e quatro isolados de pacientes com CCC obtivemos um produto de $\sim 900 \mathrm{pb}$ de tamanho esperado (897 pb). Por outro lado, para três isolados de pacientes ASS, obtivemos um produto de $\sim 500 \mathrm{pb}$ (Figura 8 ).

A seqüência de $N D 7$ foi amplificada em cepas de referência, tipificadas com base na estrutura do gene de rDNA 24S $\alpha$, como pertencentes aos grupos $T$. cruzi I, T. cruzi II, rDNA 1/2 e Zimodema 3 (Z3-A e Z3-B) (Tabela 2). Os resultados indicam um claro dimorfismo na estrutura do gene ND7 nos isolados, uma vez que apenas dois tipos de amplicons foram observados. Produtos de $\sim 900 \mathrm{pb}$ foram obtidos em isolados dos grupos $T$. cruzi I, T. cruzi II, rDNA 1/2 e Zimodema 3, ao passo que amplicons de $\sim 500 \mathrm{pb}$ foram observados apenas em algumas cepas do grupo $T$. cruzi II.

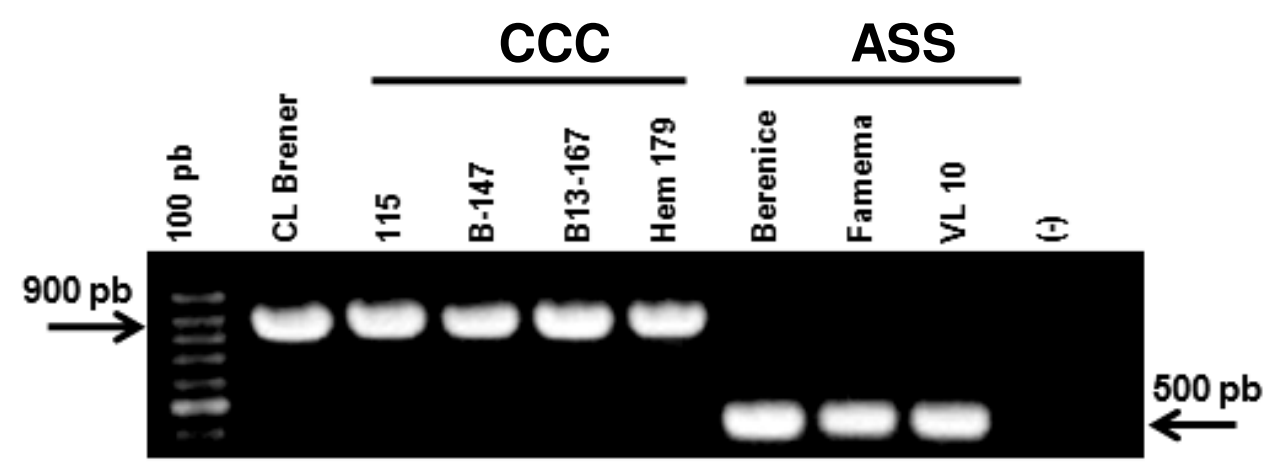

Figura 8. Produtos de amplificação do gene ND7 em isolados de pacientes com CCC e ASS. Análise em gel de agarose $0,8 \%$ corado com brometo de etídio. 
Tabela 2. Características de cepas de T. cruzi e tamanho do amplicon do gene ND7.

\begin{tabular}{l|c|c|c|c|c|c}
\hline \multicolumn{1}{c|}{ Cepa } & Grupo & Origem & Hospedeiro & Fase & Forma & Amplicon \\
\hline CL-Brener & Tc II & Rio Grande do Sul & T. infestans & NA & NA & 900 \\
\hline 115 & $1 / 2$ & Minas Gerais & Humano & Crônica & Cardíaca & 900 \\
\hline 147 & $1 / 2$ & Minas Gerais & Humano & Crônica & Cardíaca & 900 \\
\hline Colombiana & Tc I & Colômbia & Humano & Crônica & Cardíaca & 900 \\
\hline B13-167 & Tc II & Minas Gerais & Humano & Crônica & Cardíaca & 900 \\
\hline CA-1 & Tc II & San Luis, Argentina & Humano & Crônica & Cardíaca & 900 \\
\hline Hem 179 & Tc II & Minas Gerais & Humano & Crônica & Card+Dig & 900 \\
\hline Esmeraldo & Tc II & Bahia & Humano & Aguda & NA & 900 \\
\hline NRCL3 & 1/2 & Salvador, Chile & Humano & Crônica & Indeterminada & 900 \\
\hline Santa Catarina 05 & Tc II & Santa Catarina & Humano & Aguda & NA & 900 \\
\hline VL-10 & Tc II & Minas Gerais & Humano & Crônica & Indeterminada & 500 \\
\hline FAMEMA & Tc II & São Paulo & Humano & Crônica & Indeterminada & 500 \\
\hline Berenice 62 & Tc II & Minas Gerais & Humano & Crônica & Indeterminada & 500 \\
\hline Berenice 78 & Tc II & Minas Gerais & Humano & Crônica & Indeterminada & 900 \\
\hline José & Tc I & Paraíba & Humano & Crônica & Cardíaca & 900 \\
\hline SLU-31 & Tc II & Brasília, DF & Humano & Crônica & Cardíaca & 500 \\
\hline SLU-142 & Tc II & Brasília, DF & Humano & Crônica & Digestiva & 500 \\
\hline Sylvio X10 & Tc I & Pará & Humano & Aguda & NA & 900 \\
\hline Y & Tc II & São Paulo & Humano & Aguda & NA & 500 \\
\hline 2663 & Amazonas & P. geniculatus & NA & NA & 900 \\
\hline 3869 & Amazonas & Humano & Aguda & NA & 900 \\
\hline JJ & Amazonas & R. brethesi & NA & NA & 900 \\
\hline \hline TULA (F G) & Uruguai & T. infestans & NA & NA & 900 \\
\hline \hline
\end{tabular}

FONTE: Dados do Laboratorio de Biologia Molecular de Tripanossomatídeos (IQ, USP)

NOTA: ${ }^{1}$ Grupos determinados com base no tamanho do amplicon do domínio D7 do rDNA 24S $\alpha$ (SOUTO et al., 1996; MENDONÇA et al., 2002). NA = não se aplica

\subsection{SEQÜENCIAMENTO DE ND7}

A obtenção de um amplicon de $\sim 500 \mathrm{pb}$ em alguns isolados sugeriu a presença de uma ou mais deleções em ND7. Para verificar esta hipótese, os produtos de PCR de ND7 das cepas CL Brener, Silvio X10 e 115 (amplicon de 900 pb) e de VL10 e Y (amplicon de $\sim 500 \mathrm{pb}$ ) foram clonados e seqüenciados. As 
seqüências obtidas estão depositadas no GeneBank: DQ663085 (Silvio X10 cl1), DQ663084 (115), DQ663086 (VL10) e DQ663087 (Y). As seqüências foram submetidas à análise de similaridade e alinhadas com as seqüências consenso dos maxicírculos de CL Brener (GenBank: DQ343645.1) e Esmeraldo (GenBank: DQ343646.1) (Figura 9).
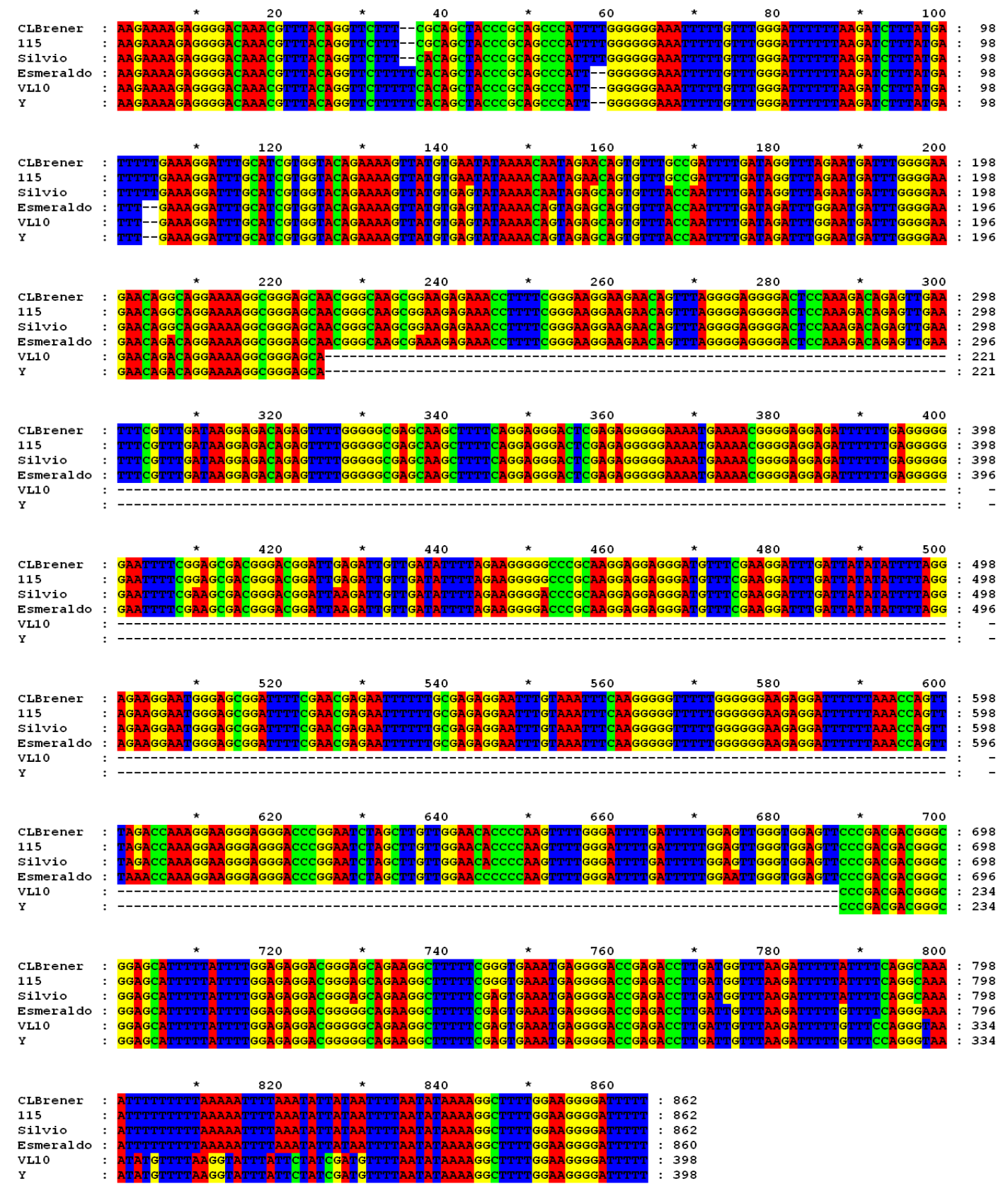

Figura 9. Alinhamento das seqüencias de ND7 das cepas CL Brener, 115, Silvio X10, Esmeraldo, VL 10 e Y. 
As seqüências de ND7 das cepas com produto de amplificação de $\sim 900 \mathrm{pb}$ apresentaram elevada similaridade (96 a 100\%) com as seqüências de Esmeraldo e CL Brener, previamente determinadas (WESTENBERGER et al., 2006). Por outro lado, uma deleção idêntica de 455 pb foi detectada nas seqüências de ND7 das cepas VL10 e Y, localizada entre as posições 222 a 677 nt do gene ND7 pré-editado de CL Brener (ver esquema na Figura 10). Ressalta-se que esta deleção, situada na região central do gene $N D 7$, elimina cerca de $50 \%$ de sua seqüência. Conforme descrito no artigo anexo (BAPTISTA et al., 2006), transcritos de 500 nt são observados nas cepas que apresentam a deleção, em contraposição a transcritos de $\sim 1000$ nt observados nas cepas que apresentam o gene "normal".

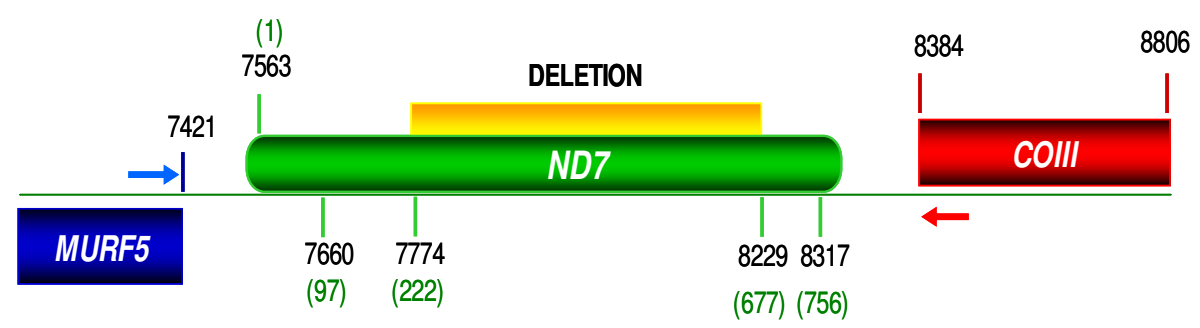

Figura 10. Representação esquemática da região que contém os genes MURF5, ND7 e COIII no maxicírculo de $T$. cruzi e localização da deleção no gene ND7. As setas indicam a posição dos iniciadores utilizados na PCR.

FONTE: Modificado de Baptista et al., 2006.

\subsection{VALIDAÇÃO DA REAÇÃO DIAGNÓSTICA DE PCR PARA ND7 EM ISOLADOS HUMANOS}

Para verificar a hipótese de que a estrutura do gene ND7 poderia ser um alvo para o diagnóstico da cepa infectante e estar relacionada com a manifestação clínica, estabelecemos colaboração com a Dra. Eliane Gontijo do Departamento de Medicina Preventiva, FM-UFMG e com o Prof. Dr. Egler Chiari e Dra. Lúcia Galvão do Departamento de Parasitologia, ICB-UFMG que forneceram 75 isolados de pacientes crônicos com sorologia positiva para a doença de Chagas, provenientes 
do estado de Minas Gerais. Neste estado, a doença de Chagas é endêmica e a transmissão vetorial foi interrompida. A apresentação clínica dos pacientes foi determinada por eletrocardiograma, ecocardiograma, monitoramento por Holter e RX de tórax, cólon e esôfago. As amostras foram enviadas codificadas. Deve ser ressaltado que os isolados foram obtidos na mesma época em que o diagnóstico clínico foi realizado e que estas cepas foram mantidas em cultura por um curto período de tempo para minimizar possível seleção de sub-populações do parasita.

Os sedimentos congelados de formas epimastigotas foram processados para a purificação do DNA e este foi submetido a ensaios de PCR para a amplificação do gene ND7. Em todas as amostras obtivemos PCR positivas, com amplicons de 900 ou 500 pb, confirmando a conservação do dimorfismo do gene ND7.

\subsubsection{Características dos pacientes}

Uma vez obtidos os resultados da PCR, foi aberto o código dos pacientes. Na amostra, $58,7 \%$ (44/75) dos pacientes eram do sexo feminino e $41,3 \%$ (31/75), do sexo masculino.

A manifestação clínica dos 75 pacientes, todos com sorologia positiva para a doença de Chagas em dois testes diagnósticos, foi avaliada pelos exames descritos acima, concluindo-se que 19 indivíduos apresentavam CCC e 56 indivíduos eram assintomáticos.

Na Figura 11 mostra-se a distribuição de gênero, apresentação clínica e faixa etária dos pacientes. Nota-se que os pacientes com a forma indeterminada (ASS) predominam na amostra $(74,6 \%)$ e se distribuem preferencialmente na faixa de 31 a 40 anos. Os pacientes com CCC, que perfazem $25,4 \%$ da amostra, prevalecem na faixa de 41 a 50 anos. 


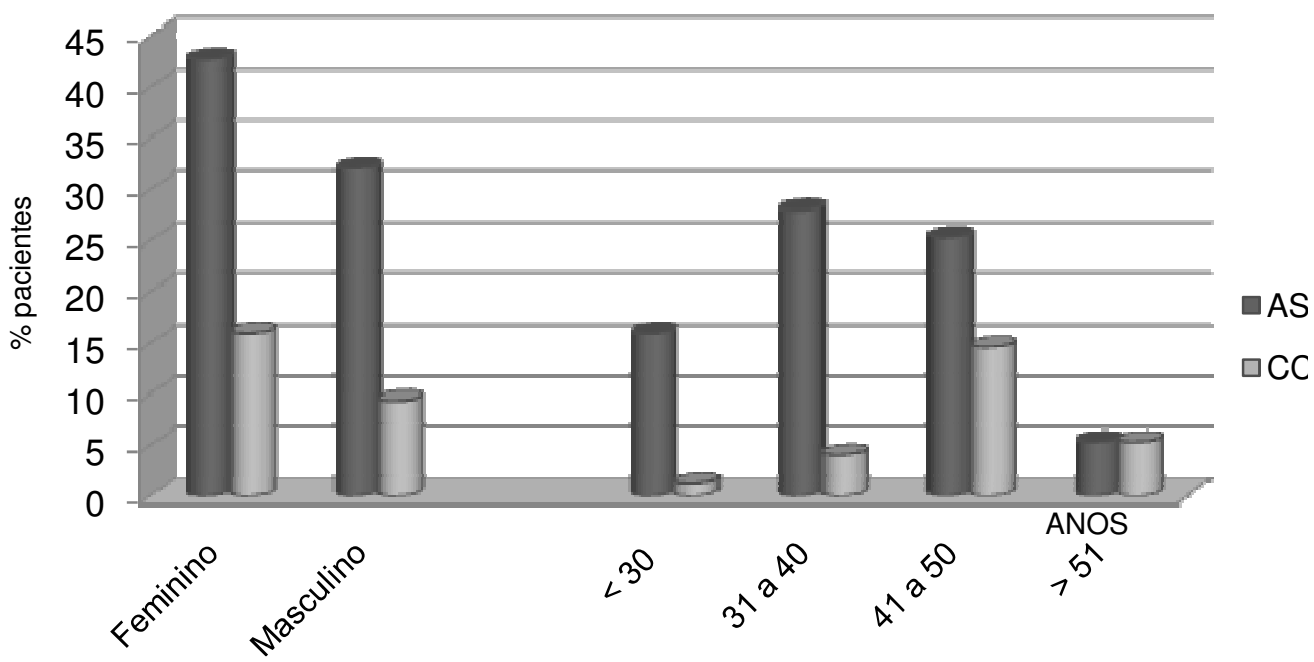

Figura 11. Distribuição de gênero, apresentação clínica e faixa etária dos pacientes.

\subsubsection{Manifestação clínica da doença de Chagas e produto de amplificação de ND7}

O ensaio de PCR para ND7 foi positivo para todos os 75 isolados. A distribuição dos amplicons de ND7 nas classes de pacientes ASS e com CCC foi determinada (Figura 12). Nos isolados de pacientes ASS, os amplicons de $\sim 500 \mathrm{pb}$ e $\sim 900$ pb foram obtidos, respectivamente, em $46,4 \%$ (26/56) e 44,6\% (25/56) das amostras. Nos isolados de indivíduos com CCC, os amplicons de $\sim 500$ pb e $\sim 900$ pb foram obtidos, respectivamente, em $58 \%$ (11/19) e $42 \%$ (8/19) das amostras. Ambos amplicons foram observados em 5 isolados de pacientes ASS.

De acordo com nossa hipótese de trabalho, se um paciente ASS fosse portador de uma cepa com amplicon de ND7 de $\sim 900 \mathrm{pb}$, haveria a possibilidade de ele vir a desenvolver CCC. Isto poderia explicar a presença de amplicons de $\sim 900 \mathrm{pb}$ em $44,6 \%$ de pacientes ASS. Por outro lado, a presença de amplicons de $\sim 500 \mathrm{pb}$ em $58 \%$ dos pacientes com CCC refuta nossa hipótese de que o gene ND7 poderia ser utilizado como marcador da cepa infectante e, conseqüentemente, para o prognóstico da evolução clínica da doença de Chagas. Interessantemente, observamos que de 11 indivíduos que apresentavam CCC e deleção em ND7, 10 pacientes (91\%) eram do sexo feminino. 


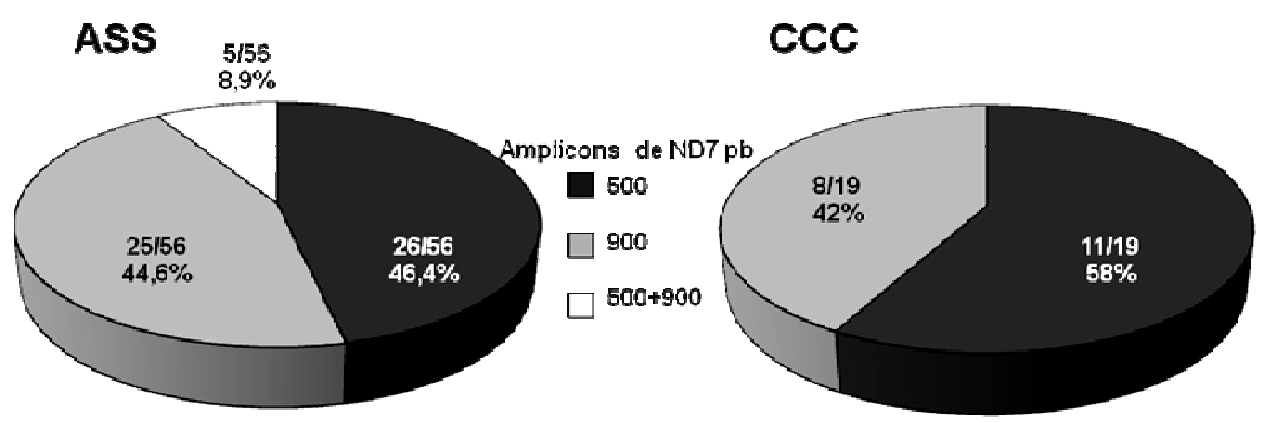

Figura 12. Distribuição do tamanho do amplicon de ND7 em isolados de pacientes ASS e com CCC.

\subsubsection{Análise da estrutura de ND7 em isolados com dois amplicons}

Conforme se comentou acima, o DNA de cinco isolados originou dois amplicons de ND7. Na Figura 13, mostra-se o padrão de amplificação em quatro destes isolados, juntamente com amostras que originam apenas um produto de amplificação. Notam-se diferenças na intensidade dos dois produtos e que, em três amostras, predomina o amplicon de $\sim 900$ pb. O ensaio de PCR foi repetido, variando-se as concentrações de DNA (Tabela 3). Não se obteve amplificação quando as concentrações de DNA foram muito elevadas. Nas demais concentrações, os dois amplicons foram obtidos. Estes resultados sugerem que os pacientes cujos isolados originam dois produtos de amplificação de ND7 estariam infectados no mínimo com duas populações distintas de T. cruzi.

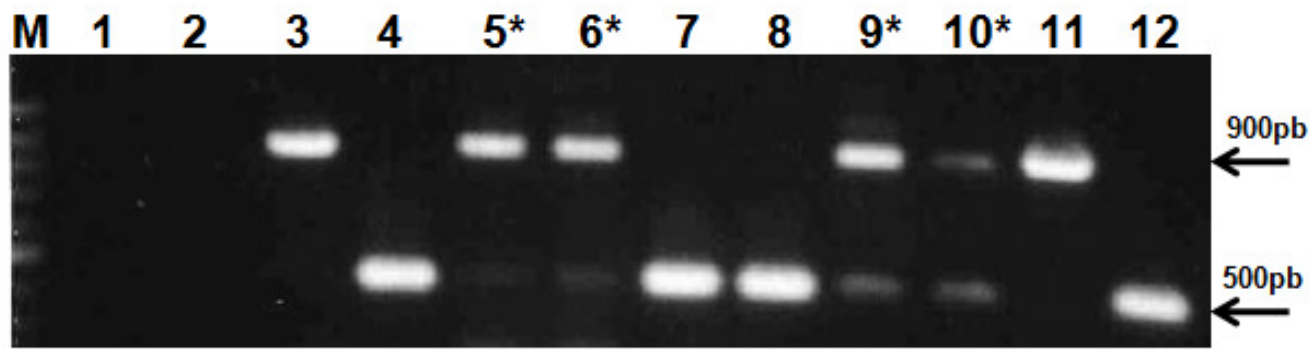

Figura 13. Produtos de amplificação de ND7 em isolados de $T$. cruzi. Os isolados que originam os dois produtos de amplificação são indicados com asterisco. Análise em gel de agarose 0,8\%. Canaletas: $M$, marcador de 100 pb; 1 e 2, Controles negativos; 3 a 10, isolados humanos; 11, CL Brener; 12, VL-10. 
Tabela 3. Reações de amplificação de ND7 variando-se a concentração de DNA molde.

\begin{tabular}{|c|c|c|c|}
\hline Amostra $^{a}$ & DNA (ng/ $\mu \mathrm{l})$ & Amplicon de 500 pb & Amplicon de $900 \mathrm{pb}$ \\
\hline \multirow{4}{*}{40} & 1600 & - & - \\
\hline & 800 & + & +++ \\
\hline & 100 & + & +++ \\
\hline & 50 & + & +++ \\
\hline \multirow{4}{*}{42} & 1200 & - & - \\
\hline & 600 & + & +++ \\
\hline & 100 & + & +++ \\
\hline & 50 & + & +++ \\
\hline \multirow{4}{*}{65} & 500 & - & - \\
\hline & 250 & + & +++ \\
\hline & 100 & + & +++ \\
\hline & 50 & + & +++ \\
\hline \multirow{4}{*}{69} & 1000 & - & - \\
\hline & 500 & + & + \\
\hline & 100 & + & + \\
\hline & 50 & - & - \\
\hline
\end{tabular}

\footnotetext{
a Amostras em que há dois amplicons de ND7

+++: Resultado positivo, banda de intensidade alta;

+ : Resultado positivo, banda de intensidade baixa;

- : Resultado negativo.
}

\subsubsection{Seqüenciamento do produto de amplificação de ND7 de isolados humanos}

Tendo por objetivo verificar a conservação da seqüência de $N D 7 \mathrm{em}$ isolados humanos, os amplicons de $\sim 900$ e $\sim 500$ pb de algumas cepas, incluindo-se as amostras que originaram ambos amplicons, foram purificados clonados $e$ seqüenciados. Os alinhamentos das seqüências são apresentados nas Figuras $14 \mathrm{e}$ 15. As seqüências do amplicon de $\sim 900$ pb apresentaram $\sim 97 \%$ de identidade com a seqüência da cepa Esmeraldo. As seqüências do amplicon de $\sim 500$ pb apresentaram $\sim 99 \%$ de identidade com a seqüência da cepa VL10. 


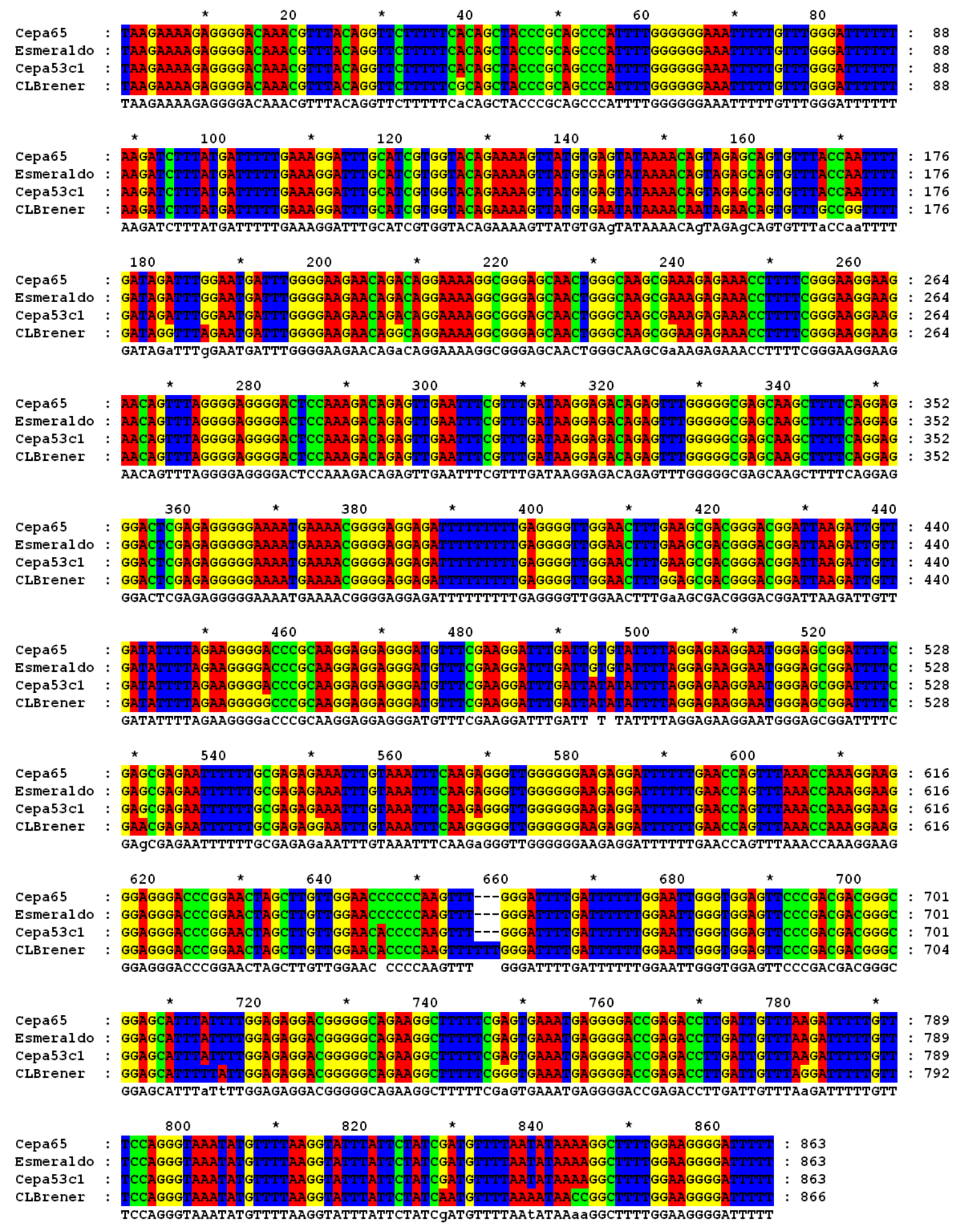

Figura 14. Alinhamento das seqüências do produto de amplificação de 2900 pb de dois isolados humanos com as seqüências de ND7 das cepas Esmeraldo e CL Brener. 

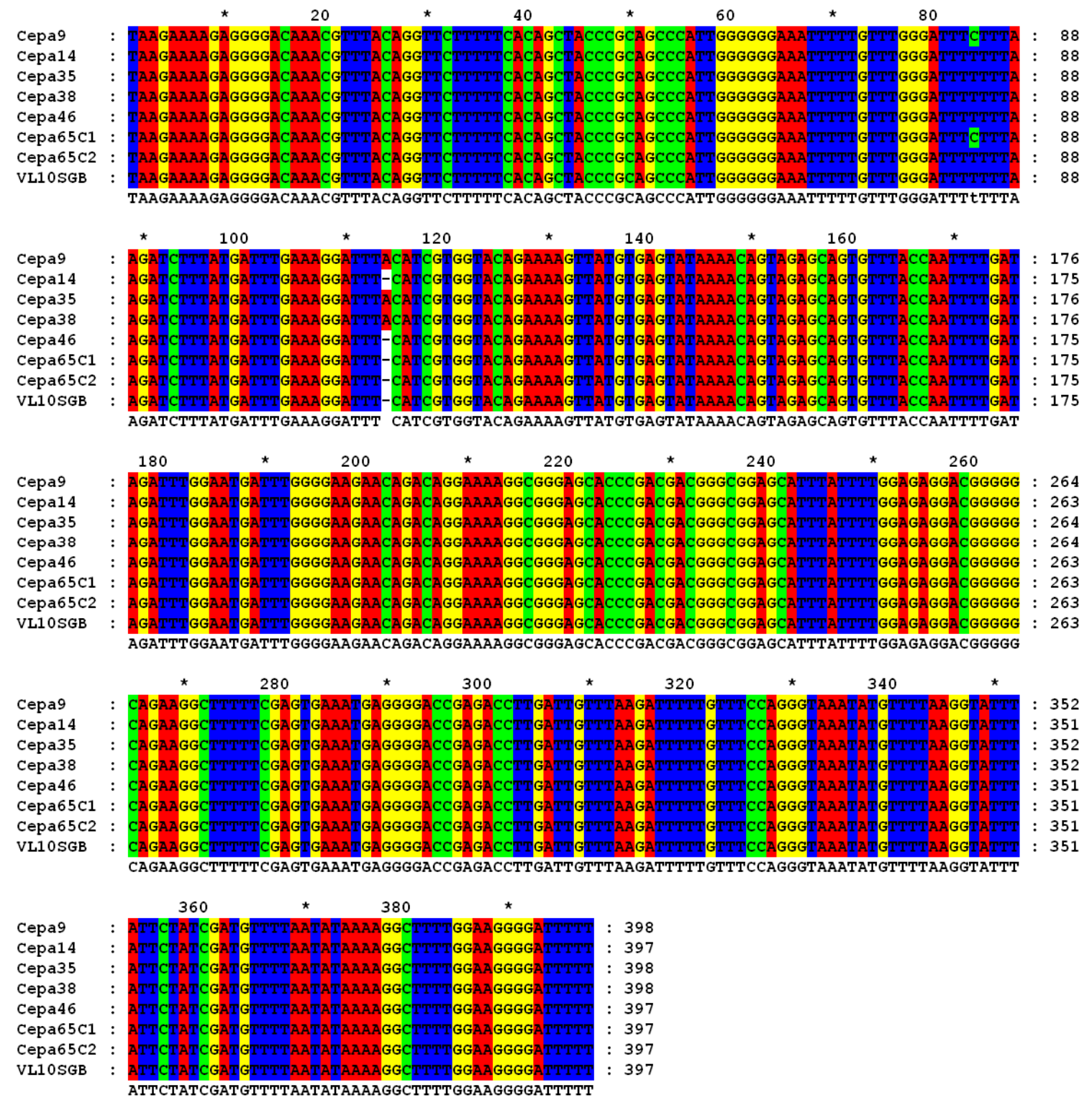

Figura 15. Alinhamento das seqüências do produto de amplificação de $\sim 500$ pb de isolados humanos com a seqüência da cepa VL 10. As seqüencias Cepa 65 c0 e cepa 65 c1 são de dois clones do produto de 500 pb do isolado 65.

\subsection{ESTRUTURA DO GENE DA SUBUNIDADE III DA CITOCROMO OXIDASE (COIII) E SUBUNIDADE 4 DA NADH DESIDROGENASE (ND4)}

Para verificar se haveria modificações estruturais em outros genes localizados no maxicírculo de T. cruzi, padronizamos um ensaio de PCR para amplificar o gene COIII, contíguo ao gene ND7 (posição 3678 a 4100 nt) (ver Figura 7 da Introdução) (WESTENBERGER et al., 2006). Para isto, foram desenhados os iniciadores CO1 e 
CO2 que hibridizam nas regiões que flanqueiam o gene COIII de CL Brener (GeneBank: DQ343645). Um produto de $\sim 700 \mathrm{pb}$ de tamanho esperado (658 pb) foi obtido para 4 isolados de pacientes com CCC e três de ASS (Figura 16). Esta análise se estendeu para 33 isolados humanos: 14 com CCC e 19 ASS (Tabela 4). Ressalta-se que em 3 isolados não obtivemos produto de amplificação.

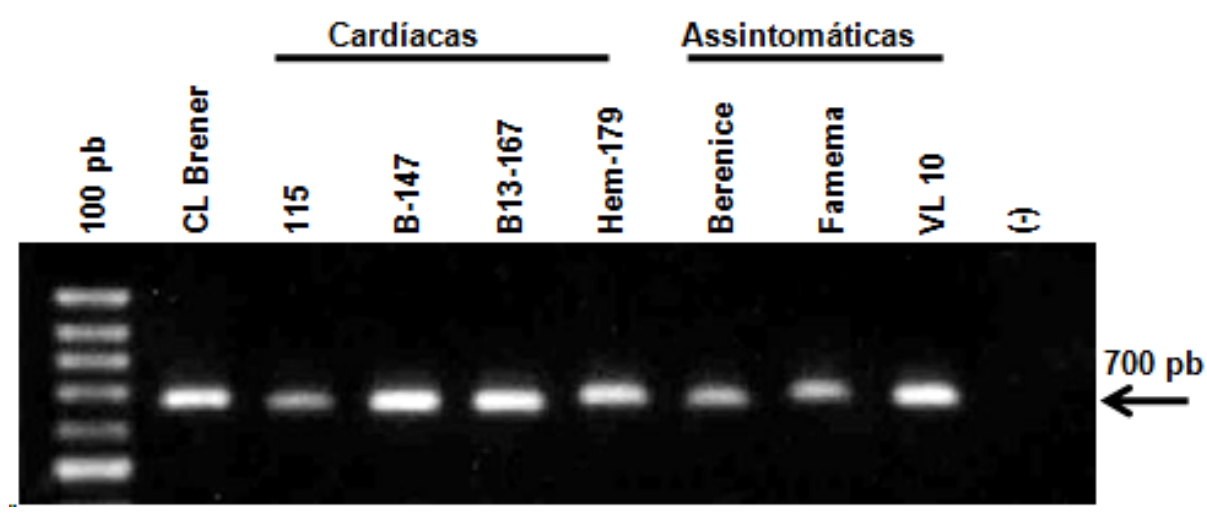

Figura 16. Produtos de amplificação do gene Colll. Análise em gel de agarose $0,8 \%$ corado com brometo de etídio.

A comparação da seqüência dos maxicírculos de CL Brener e Esmeraldo indicou a presença de uma deleção de 236 pb em Esmeraldo que remove o início da região 5' dos genes CR4 e ND4, bem como a região intergênica (WESTENBERGER et al., 2006). Decidimos investigar a estrutura de ND4 em isolados humanos, utilizando o ensaio de PCR descrito em Material e Métodos, que fornece para a cepa CL Brener um produto de $530 \mathrm{pb}$ e para a cepa Esmeraldo, um produto de $300 \mathrm{pb}$ (Figura 17). Aplicamos esta PCR para 33 isolados humanos (Tabela 4). Em 10 amostras (10/33; 30\%) não obtivemos amplificação. Nas restantes, o amplicon de $530 \mathrm{pb}$ foi verificado em 18 isolados; o de $300 \mathrm{pb}$ em 4 isolados e ambos os amplicons em 1 isolado.

A não amplificação dos genes COIIl e ND4 em alguns isolados não pode ser atribuída à má qualidade do DNA, pois nestas amostras houve amplificação de ND7 (Tabela 4). Muito provavelmente a não amplificação deve-se a variações de seqüência nas regiões onde os iniciadores foram desenhados. 


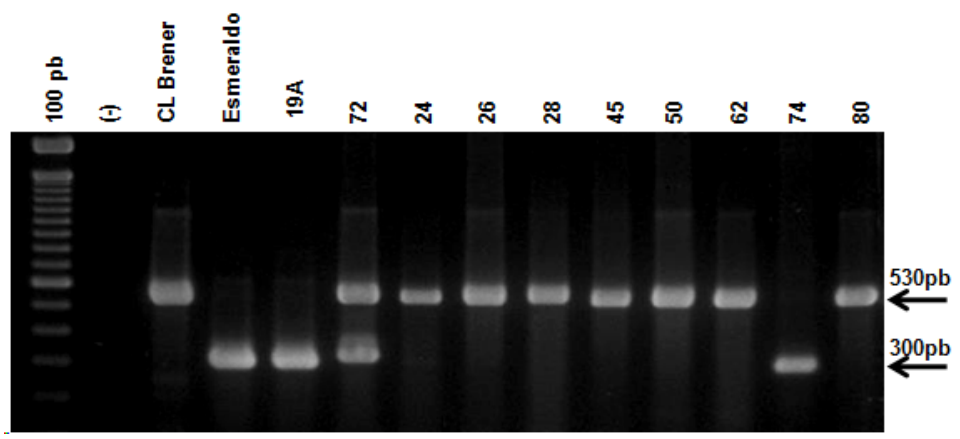

Figura 17. Produtos de amplificação do gene ND4. Análise em gel de agarose $0,8 \%$ corado com brometo de etidio. Os números acima das canaletas indicam o código de isolados humanos.

Tabela 4. Estrutura dos genes ND7, ND4 e COIIl em isolados humanos. Análise por PCR.

\begin{tabular}{|c|c|c|c|c|}
\hline Isolado & Manifestação & ND7 & ND4 & COIII \\
\hline 1 & CCC & deleção & normal & normal \\
\hline 2 & $\mathrm{CCC}$ & deleção & normal & normal \\
\hline 5 & ASS & normal & deleção & normal \\
\hline 19 & CCC & normal & deleção & normal \\
\hline 21 & ASS & normal & NA & normal \\
\hline 22 & ASS & deleção & normal & normal \\
\hline 23 & ASS & deleção & normal & normal \\
\hline 24 & CCC & normal & normal & normal \\
\hline 26 & ASS & deleção & normal & normal \\
\hline 28 & ASS & deleção & normal & normal \\
\hline 32 & $\mathrm{CCC}$ & normal & normal & normal \\
\hline 36 & $\mathrm{CCC}$ & normal & NA & normal \\
\hline 38 & ASS & deleção & normal & normal \\
\hline 39 & ASS & deleção/normal & normal & NA \\
\hline 40 & $\mathrm{CCC}$ & deleção/normal & normal & normal \\
\hline 42 & ASS & deleção/normal & normal & normal \\
\hline 65 & ASS & deleção/normal & NA & NA \\
\hline 69 & ASS & deleção/normal & NA & NA \\
\hline 45 & ASS & deleção & normal & normal \\
\hline 46 & ASS & deleção & NA & normal \\
\hline 50 & ASS & normal & normal & normal \\
\hline 53 & ASS & normal & NA & normal \\
\hline 54 & CCC & normal & normal & normal \\
\hline 55 & ASS & normal & NA & normal \\
\hline 59 & ASS & deleção & $\mathrm{NA}$ & normal \\
\hline 62 & ASS & normal & normal & normal \\
\hline 67 & CCC & normal & $\mathrm{NA}$ & normal \\
\hline 72 & CCC & normal & deleção/normal & normal \\
\hline 73 & CCC & normal & deleção & normal \\
\hline 74 & ASS & normal & deleção & normal \\
\hline 75 & CCC & deleção & normal & normal \\
\hline 80 & CCC & deleção & normal & normal \\
\hline 88 & $\mathrm{CCC}$ & deleção & NA & normal \\
\hline
\end{tabular}

NA - Não amplifica 


\subsection{DETERMINAÇÃO DE PARÂMETROS FUNCIONAIS DA MITOCÔNDRIA.}

\subsubsection{Estudo da função de complexos I e II da respiração mitocondrial}

Conforme comentado acima, a deleção no gene ND7 promove o aparecimento de transcritos que apresentam a metade do tamanho dos transcritos observados nas cepas sem deleção. No caso do transcrito ser editado e expresso, quase certamente, originará uma subunidade 7 não funcional. Para investigar se a deleção em ND7 afeta a cadeia de transporte de elétrons, determinamos o consumo de oxigênio em formas epimastigotas de algumas cepas (CL Brener, Esmeraldo e 115, sem deleção e Famema e VL 10, com deleção), permeabilizadas com digitonina, utilizando substratos respiratórios do complexo I e II mitocondrial. Deve ser lembrado que a cepa Esmeraldo apresenta deleção no gene ND4 que codifica outra subunidade do complexo I. Esta deleção eliminaria o primeiro domínio transmembrana da proteína (WESTENBERGER et al., 2006). Os estudos relacionados com a bioenergética mitocondrial foram realizados em colaboração com a Dra. Alícia Kowaltowski do Departamento de Bioquímica, IQ-USP.

Vários parâmetros foram padronizados antes do início dos experimentos.

\subsubsection{Determinação da viabilidade dos parasitas no tampão de respiração}

Formas epimastigotas de CL Brener foram incubadas no tampão descrito em Material e Métodos por um período de até 12 horas a $28{ }^{\circ} \mathrm{C}$. A viabilidade das células foi monitorada com azul de tripan (Figura 18). Observa-se que os parasitas apresentam 100\% de viabilidade durante as primeiras seis horas. 


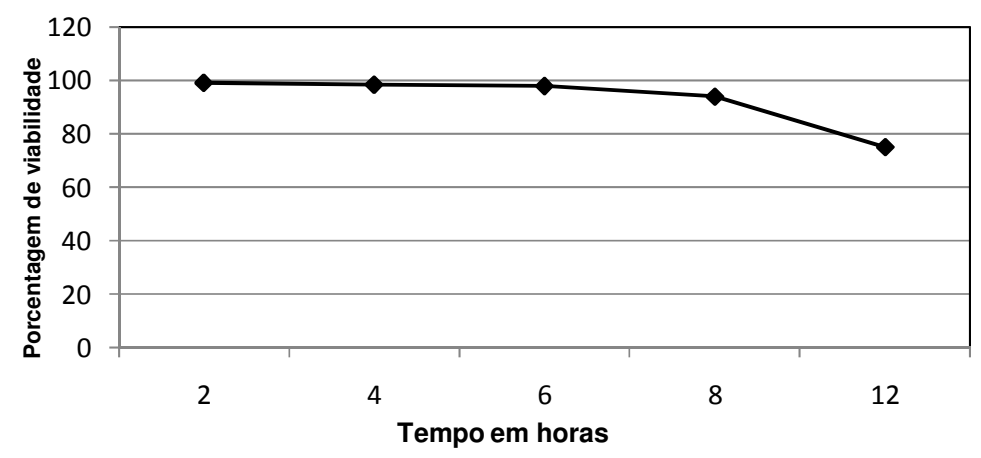

Figura 18. Porcentagem de viabilidade de formas epimastigotas de CL Brener mantidas em tampão de respiração.

\subsubsection{Determinação da concentração de digitonina para permeabilização da membrana plasmática}

Inicialmente, determinamos o consumo de oxigênio em formas epimastigotas de CL Brener não permeabilizadas, utilizando um eletrodo tipo Clark fixado a um oxígrafo HansaTech ${ }^{\circledR}$. Observamos um elevado consumo de oxigênio, que não se modifica após adição de ADP e/ou succinato (dados não mostrados). Isto indica que a membrana plasmática dos parasitas é impermeável a estes compostos.

Para determinar a concentração de digitonina necessária para permeabilizar seletivamente a membrana plasmática sem afetar as membranas mitocondriais, os epimatigotas ( $5 \times 10^{7}$ células $/ \mathrm{mL}$ ) foram incubados com quantidades crescentes deste reagente, em presença de succinato como substrato respiratório e ADP. O controle respiratório ( $\mathrm{CR}$ ) foi determinado conforme descrito em Material e Métodos e no item seguinte. Os dados da Figura 19 mostram um incremento progressivo do CR nas adições consecutivas de digitonina. CR máximo de $~ 2,0$ foi obtido com 64 $\mu \mathrm{M}$ de digitonina, após o que, o CR apresentou uma clara diminuição. Desta forma, adotamos a concentração de $64 \mu \mathrm{M}$ de digitonina para a permeabilização das células, uma vez que, nestas condições, os processos de respiração e fosforilação se mantiveram acoplados. 


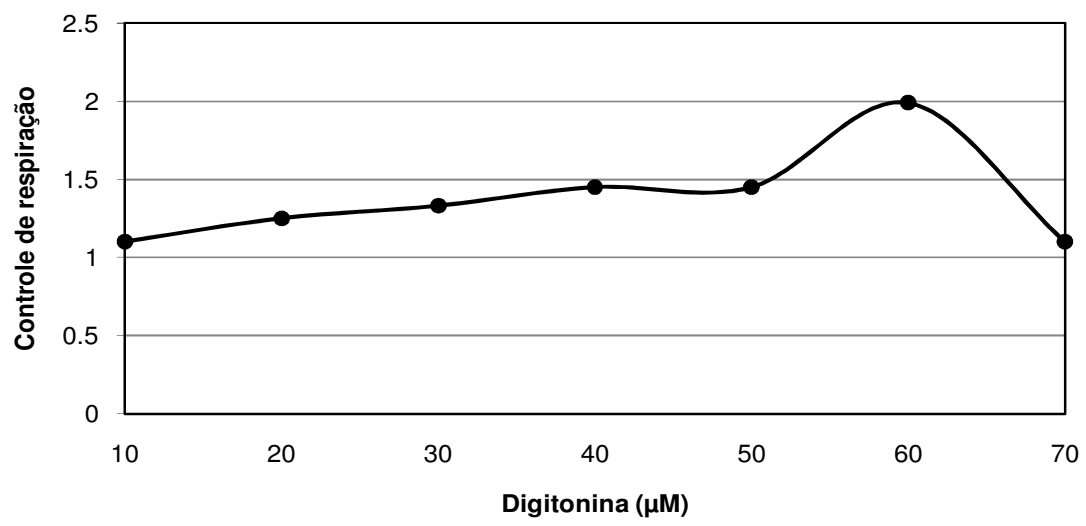

Figura 19. Determinação do controle de respiração em epimastigotas de CL Brener permeabilizados com digitonina.

\subsubsection{Determinação do controle respiratório}

Nos experimentos descritos a seguir foram utilizadas formas epimastigotas, em fase exponencial de crescimento, permeabilizadas com digitonina.

Para investigar a funcionalidade dos complexos I e II da respiração mitocondrial, utilizamos o parâmetro CR que é obtido a partir da relação entre a velocidade de consumo de oxigênio na presença de substratos respiratórios e ADP (estado III) e a velocidade de consumo de oxigênio após esgotamento do ADP e inibição da ATP sintase com oligomicina (estado IV). A adição do protonóforo desacoplador CCCP, na concentração utilizada $(1 \mu \mathrm{M})$, aumenta o consumo de oxigênio que atinge o nível observado após adição de ADP.

Na Figura 20 mostramos um traçado típico do consumo de oxigênio em função da adição de reagentes. 


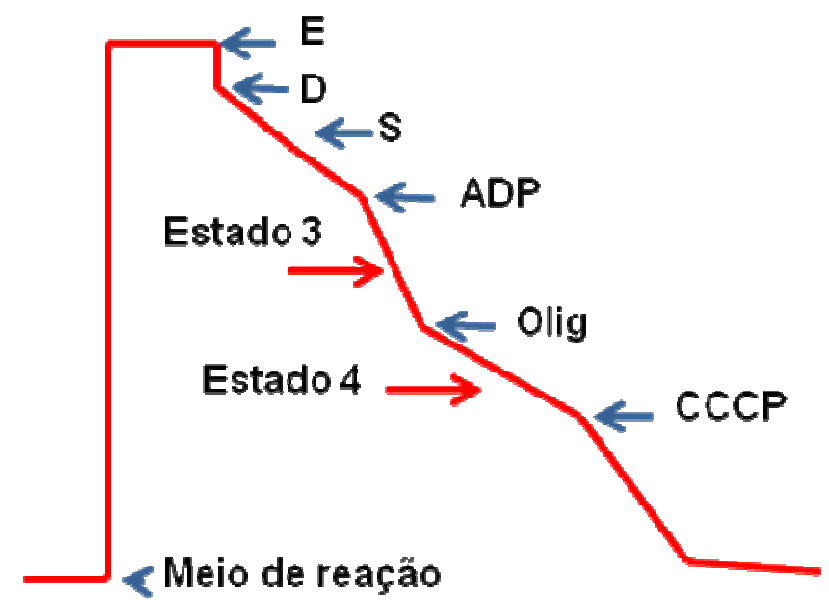

$\mathrm{E}=$ Epimastigotas; $\mathrm{D}$ = Digitonina; $\mathrm{S}$ = Substratos respiratórios dos complexos I ou II; Olig = Oligomicina; CCCP = desacoplador .

Figura 20. Esquema do traçado do consumo de oxigênio em função da adição de reagentes.

\subsubsection{Determinação do CR com substratos do complexo I}

A capacidade da cadeia respiratória mitocondrial de oxidar NADH via complexo I foi determinada em presença dos substratos piruvato e malato. Os ensaios foram realizados em triplicata, em dias diferentes. Na Tabela 5 apresenta-se a média e o desvio padrão (dp) da velocidade de consumo de oxigênio no estado III e estado IV. Para cada experimento foi determinado o $\mathrm{CR}$ e, em seguida, a média e dp (Tabela 5). Nota-se que não há diferenças no valor do $C R$ em cepas que apresentam o gene ND7 e ND4 normal ou com deleção.

\subsubsection{Determinação do CR com substratos do complexo II}

A capacidade da cadeia respiratória para oxidar succinato via complexo II foi determinada. Os ensaios foram realizados em triplicata. Na Tabela 6 apresenta-se a média e dp da velocidade de consumo de oxigênio no estado III e estado IV. Para cada experimento foi determinado o CR e, em seguida, a média e dp (Tabela 6). Nota-se que não há diferenças significativas no valor do $C R$ entre as cepas. 
Tabela 5. Velocidade de consumo de oxigênio e CR com substratos do complexo I em isolados de T. cruzi

\begin{tabular}{|c|c|c|c|c|c|}
\hline & \multicolumn{3}{|c|}{ ND7 normal } & \multicolumn{2}{|c|}{ ND7 com deleção } \\
\hline & CL Brener & Esmeraldo $^{a}$ & 115 & VL10 & Famema \\
\hline \multicolumn{6}{|c|}{$\begin{array}{c}\text { Velocidade (média } \pm \mathrm{dp}) \\
\left(\text { nmoles de } \mathrm{O}_{2} \times \text { mg de proteína }^{-1} \times \text { minuto }^{-1}\right)\end{array}$} \\
\hline Estado III & $4,86 \pm 0,8$ & $4,14 \pm 0,24$ & $4,22 \pm 0,27$ & $4,59 \pm 0,4$ & $4,5 \pm 0,75$ \\
\hline Estado IV & $2,12 \pm 0,74$ & $1,9 \pm 0,07$ & $1,99 \pm 0,15$ & $1,96 \pm 0,45$ & $1,85 \pm 0,27$ \\
\hline \multicolumn{6}{|c|}{$\begin{array}{l}\text { CR (média } \pm \text { dp) } \\
\text { (estado III/estado IV) }\end{array}$} \\
\hline & $2,29 \pm 0,4$ & $2,17 \pm 0,07$ & $2,12 \pm 0,2$ & $2,34 \pm 0,34$ & $2,43 \pm 0,33$ \\
\hline
\end{tabular}

${ }^{a}$ A cepa Esmeraldo apresenta ND4 com deleção.

Tabela 6. Velocidade de consumo de oxigênio e CR com substrato do complexo II em isolados de $T$. cruzi.

\begin{tabular}{|c|c|c|c|c|c|}
\hline & \multicolumn{3}{|c|}{ ND7 normal } & \multicolumn{2}{|c|}{ ND7 com deleção } \\
\hline & CL Brener & Esmeraldo $^{a}$ & 115 & VL10 & Famema \\
\hline \multicolumn{6}{|c|}{$\begin{array}{c}\text { Velocidade (média } \pm \mathrm{dp}) \\
\left(\text { nmoles de } \mathrm{O}_{2} \times \mathrm{mg} \text { de proteína }{ }^{-1} \times \text { minuto }^{-1}\right)\end{array}$} \\
\hline Estado III & $4,35 \pm 0,35$ & $3,99 \pm 0,26$ & $4,36 \pm 0,9$ & $3,76 \pm 0,46$ & $3,55 \pm 0,8$ \\
\hline Estado IV & $1,98 \pm 0,56$ & $2,04 \pm 0,2$ & $1,59 \pm 0,24$ & $1,75 \pm 0,45$ & $1,63 \pm 0,07$ \\
\hline \multicolumn{6}{|c|}{$\begin{array}{l}\text { CR (média } \pm \text { dp) } \\
\text { (estado III/estado IV) }\end{array}$} \\
\hline & $2,2 \pm 0,69$ & $1,96 \pm 0,32$ & $2,74 \pm 0,35$ & $2,20 \pm 0,4$ & $2,17 \pm 0,63$ \\
\hline
\end{tabular}

${ }^{a}$ A cepa Esmeraldo apresenta ND4 com deleção.

\subsubsection{Atividade da cadeia respiratória em presença de malonato}

Os resultados obtidos indicam não haver diferenças significativas no valor de CR nas cepas que apresentam os genes ND7 e ND4 normal ou com deleção, 
utilizando substratos dos complexos I ou II de respiração. Estes resultados poderiam indicar que a deleção nos dois genes não afeta a atividade do complexo I. Outra possibilidade seria a de que o complexo I não é funcional em $T$. cruzi e que o NADH formado a partir dos substratos malato e piruvato não seria oxidado via complexo I, mas sim por uma fumarato redutase, gerando succinato (ver reação abaixo e Figuras 2 e 3 na Introdução). Este substrato seria então oxidado via complexo II. A atividade da fumarato redutase mitocondrial foi descrita em T. cruzi (BOVERIS et al., 1986).

$$
\text { Fumarato }+\mathrm{NADH} \longleftrightarrow \text { Succinato }+\mathrm{NAD}^{+}
$$

Para avaliar indiretamente esta segunda hipótese, decidimos utilizar o composto malonato, o qual é um inibidor competitivo da succinato desidrogenase (complexo II), por ser estruturalmente semelhante ao succinato. A ação inibitória de malonato foi verificada em T. cruzi (DENICOLA-SEOANE et al., 1992). Se o sistema $\mathrm{NADH}$-fumarato redutase fosse atuante na oxidação do $\mathrm{NADH}$, o malonato deveria inibir a velocidade de consumo de oxigênio e, por conseguinte, o CR, seja com substratos do complexo I, seja com substratos do complexo II. Por outro lado, se o complexo I fosse funcional, o CR obtido com os substratos malato e piruvato não seria inibido por malonato. Nos ensaios cujos resultados são apresentados na Tabela 7, com substratos de complexo I e Tabela 8 com substrato para complexo II, utilizamos as cepas CL Brener (ND7 normal) e VL 10 (ND7 com deleção) e malonato na concentração de $10 \mathrm{mM}$.

Utilizando-se substratos do complexo I, observa-se que malonato inibe $52 \%$ e $56 \%$ a velocidade de consumo de oxigênio no estado III nas cepas CL Brener e VL10, respectivamente (Tabela 7). O CR é inibido 48 e 45\% nas mesmas cepas. Quando foi utilizado succinato como substrato de complexo II, malonato inibiu 60,3\% e $51,3 \%$ a velocidade de consumo de oxigênio no estado III nas cepas CL Brener e VL10, respectivamente (Tabela 8 ). Uma inibição de $50 \%$ foi observada no CR das duas cepas. 
Tabela 7. Velocidade de consumo de oxigênio e CR com substratos de complexo I com e sem adição de malonato.

\begin{tabular}{|c|c|c|c|c|c|c|}
\hline \multicolumn{4}{|c|}{ CL Brener } & \multicolumn{3}{|c|}{ VL10 } \\
\hline & - Malonato & + Malonato & \% Inibição & - Malonato & + Malonato & \% Inibição \\
\hline \multicolumn{7}{|c|}{$\begin{array}{l}\text { Velocidade (média } \pm \mathrm{dp} \text { ) } \\
\text { (nmoles de } \mathrm{O}_{2} \times \mathrm{mg}^{-1} \text { de proteína }{ }^{-1} \times \text { minuto }^{-1} \text { ) }\end{array}$} \\
\hline Estado III & $4,33 \pm 0,4$ & $2,04 \pm 0,3$ & $52,3 \pm 6,6$ & $3,95 \pm 0,4$ & $1,69 \pm 0,01$ & $56,6 \pm 3,8$ \\
\hline \multicolumn{7}{|c|}{$\begin{array}{l}\text { CR (média } \pm d p) \\
\text { (Estado III/Estado IV) }\end{array}$} \\
\hline & $2,38 \pm 0,4$ & $1,14 \pm 0,1$ & 47,9 & $2,39 \pm 0,3$ & $1,08 \pm 0,1$ & 45,2 \\
\hline
\end{tabular}

Tabela 8. Velocidade de consumo de oxigênio e CR com substrato de complexo II com e sem adição de malonato em isolados de $T$. cruzi

\begin{tabular}{|c|c|c|c|c|c|c|}
\hline \multicolumn{4}{|c|}{ CL Brener } & \multicolumn{3}{|c|}{ VL10 } \\
\hline & - Malonato & + Malonato & \% Inibição & - Malonato & + Malonato & \% Inibição \\
\hline \multicolumn{7}{|c|}{$\begin{array}{l}\text { Velocidade (média } \pm \mathrm{dp} \text { ) } \\
\text { (nmoles de } \mathrm{O}_{2} \times \text { mg de proteína }^{-1} \times \text { minuto }^{-1} \text { ) }\end{array}$} \\
\hline Estado III & $4,12 \pm 0,5$ & $1,59 \pm 0,1$ & $60,3 \pm 5$ & $4,22 \pm 0,5$ & $1,98 \pm 0,3$ & $51,3 \pm 15$ \\
\hline \multicolumn{7}{|c|}{$\begin{array}{l}\text { CR (média } \pm \text { dp) } \\
\text { (Estado III/Estado IV) }\end{array}$} \\
\hline & $2,3 \pm 0,7$ & $1,16 \pm 0,1$ & 50,4 & $2,2 \pm 0,4$ & $1,11 \pm 0,1$ & 50,5 \\
\hline
\end{tabular}

Os resultados indicam que malonato inibiu o controle respiratório via complexo II, confirmando que esta substância atua na succinato desidrogenase. Por outro lado, o malonato também inibiu a oxidação do NADH gerado pelos substratos piruvato e malato. Este resultado sugere que o segmento NADH-ubiquinona (complexo I) nestas células é pouco ativo e que o NADH seria utilizado para gerar succinato, via $\mathrm{NADH}$-fumarato redutase, o qual seria oxidado via complexo II. 


\subsection{MEDIDA DO PERÓXIDO DE HIDROGÊNIO $\left(\mathrm{H}_{2} \mathrm{O}_{2}\right)$ GERADO NA MITOCÔNDRIA}

A geração de EROs na mitocôndria é um evento fisiológico que pode ocorrer em condições de aerobiose. Foi demonstrado que substratos que são oxidados gerando $\mathrm{NADH}$ podem originar altas taxas de $\mathrm{H}_{2} \mathrm{O}_{2}$ (BOVERIS, 1976). Neste processo, os elétrons nos complexos I e III podem reduzir parcialmente o oxigênio molecular formando o radical superóxido $\left(\mathrm{O}_{2}{ }^{-}\right)$, que rapidamente é dismutado pela superóxido dismutase para peróxido de hidrogênio $\left(\mathrm{H}_{2} \mathrm{O}_{2}\right)$. Em $T$. cruzi foi demonstrado que a respiração mitocondrial gera radicais superóxido (BOVERIS e STOPPANI, 1977).

Uma vez que os dados referentes ao $\mathrm{CR}$, descritos acima, indicavam não haver diferenças entre as cepas com ND7 e ND4 normal ou com deleção, sugerindo que o complexo I não era funcional ou pouco funcional na respiração, decidimos investigar se haveria diferenças na produção de peróxido de hidrogênio mitocondrial, tendo em vista que o complexo I é um dos sítios principais de "vazamento" de elétrons (TURRENS e BOVERIS, 1980; TURRENS, 2003).

A medida de produção de $\mathrm{H}_{2} \mathrm{O}_{2}$ foi investigada em cinco cepas utilizando-se substratos para os complexos I e II, segundo metodologia descrita em Material e Métodos. Os resultados de três experimentos independentes são apresentados na Tabela 9 e indicam não haver uma correlação entre os níveis de produção de $\mathrm{H}_{2} \mathrm{O}_{2}$ mitocondrial e a presença de deleção nos genes ND7 ou ND4. Por outro lado, observam-se variações nos níveis de produção de $\mathrm{H}_{2} \mathrm{O}_{2}$ entre as cepas, o que representa um fenótipo adicional que ilustra a diversidade bioquímica e funcional das populações de $T$. cruzi. É interessante notar que a produção de peróxido de hidrogênio, tanto com os substratos de complexo I, quanto de complexo II, é baixa em algumas cepas, e que os maiores valores são observados nas cepas 115 e VL10. 
Tabela 9. Produção de $\mathrm{H}_{2} \mathrm{O}_{2}$ mitocondrial (valores em pmoles.min ${ }^{-1} \cdot \mathrm{mg}^{-1}$ ).

\begin{tabular}{c|c|c|c|c|c}
\hline \hline & \multicolumn{3}{|c|}{ ND7 normal } & \multicolumn{2}{c}{ ND7 com deleção } \\
\cline { 2 - 6 } & CL Brener & Esmeraldo $^{\mathrm{a}}$ & 115 & Famema & VL10 \\
\hline Complexo I $^{\mathrm{b}}$ & $15,8 \pm 3,5$ & $24,5 \pm 0,15$ & $28,4 \pm 1,5$ & $19,26 \pm 1,5$ & $25,5 \pm 3,4$ \\
\hline Complexo II $^{\mathrm{c}}$ & $11,9 \pm 1,7$ & $14,01 \pm 0,3$ & $25,6 \pm 3,3$ & $12,02 \pm 0,9$ & $21,35 \pm 0,5$ \\
\hline \hline
\end{tabular}

${ }^{a}$ Cepa com deleção em ND4

${ }^{\mathrm{b}}$ Substratos: Piruvato + Malato

${ }^{\mathrm{c}}$ Substrato: Succinato

\subsection{MONITORAMENTO DOS NÍVEIS DE NAD MITOCONDRIAL EM EPIMASTIGOTAS}

Tendo em vista que um dos maiores sítios de produção de EROs na mitocôndria é o complexo I da cadeia respiratória mitocondrial (TURRENS e BOVERIS, 1980; TURRENS, 2003), que deveria oxidar o NADH gerado no metabolismo, foi analisada a acumulação relativa de NADH nas cepas 115 e CL Brener que apresentaram as maiores diferenças na produção de $\mathrm{H}_{2} \mathrm{O}_{2}$ mitocondrial. Para isto, foi utilizada a propriedade do NADH de absorver luz num comprimento de onda de 352 nm e emitir luz em 464 nm.

Nos ensaios, foram adicionados antimicina A, um inibidor do complexo III que resulta num incremento de fluorescência (100\% NADH), e CCCP, um protonóforo desacoplador que causa a máxima oxidação $\left(100 \% N A D^{+}\right)$e um decréscimo de fluorescência. Na figura 21 apresenta-se um exemplo do traçado de fluorescência, expresso em unidades arbitrárias de fluorescência (UAF) e ponto de adição de reagentes. A estimativa da quantidade de NADH foi feita nas mesmas condições de reação usadas na determinação de $\mathrm{H}_{2} \mathrm{O}_{2}$ liberado pela mitocôndria. 


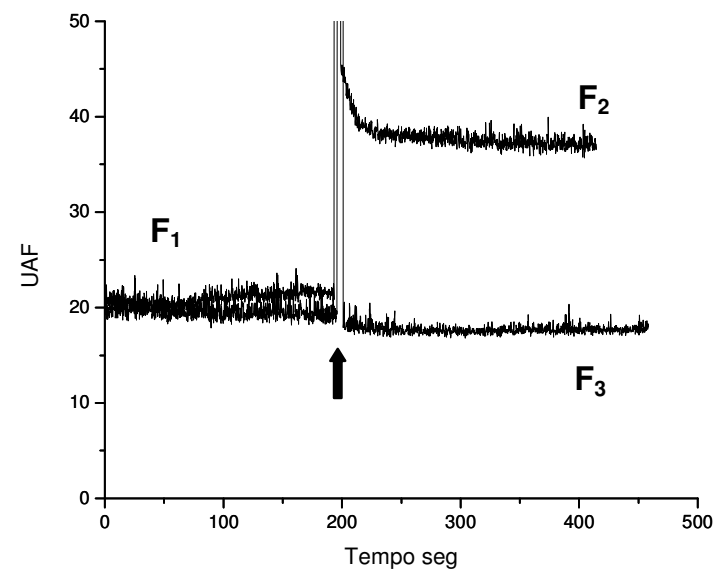

Figura 21. Traçado de fluorescência para determinação do nível de NAD mitocondrial. A seta indica o ponto de adição dos reagentes (Antimicina A e CCCP). $F_{1}$ :

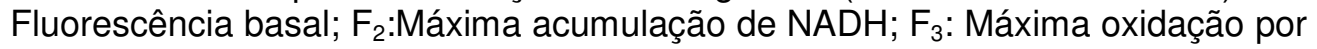
CCCP.

A média $\pm \mathrm{dp}$ da leitura de UAF de três experimentos são apresentados na Tabela 10. A quantidade relativa de $\mathrm{NAD}$ oxidado $\left(\mathrm{NAD}^{+}\right)$foi determinada pela diferença de UAF entre o traçado $F_{2}$ e $F_{1}$. A quantidade relativa de NAD reduzido (NADH) foi determinada pela diferença de UAF entre o traçado $F_{1}$ e $F_{3}$. A variação da quantidade de NAD total é obtida pela diferença entre $F_{2}$ e $F_{3}$. $O$ nível de significância dos dados $\left({ }^{*} p<0,05\right)$ foi determinado pelo teste $t$-Student.

Tabela 10. Diferenças na abundância relativa de NAD mitocondrial nas cepas 115 e CL Brener. Valores expressos como média \pm dp de unidades arbitrárias de fluorescência (UAF).

\begin{tabular}{c|c|c|c|c}
\hline \hline Substratos & \multicolumn{2}{|c|}{ Complexo I } & \multicolumn{2}{c}{ Complexo II } \\
\hline Cepas & 115 & CL Brener & 115 & CL Brener \\
\hline$\Delta \mathrm{UAF}_{\mathrm{NAD}}{ }^{+}=\mathrm{F}_{2}-\mathrm{F}_{1}$ & $21,59 \pm 0,9$ & $13 \pm 1,2$ & $19,87 \pm 1,1$ & $17,2 \pm 0,6$ \\
\hline$\Delta \mathrm{UAF}_{\mathrm{NADH}}=\mathrm{F}_{1}-\mathrm{F}_{3}$ & $0,86 \pm 0,36$ & $2,38 \pm 0,1$ & $0,51 \pm 0,2$ & $1,66 \pm 0,3$ \\
\hline$\Delta \mathrm{UAF}_{\mathrm{T}}=\mathrm{F}_{2}-\mathrm{F}_{3}$ & $23,5 \pm 2$ & $14,53 \pm 2,9$ & $22,6 \pm 1,5$ & $19,46 \pm 1,3$ \\
\hline \hline
\end{tabular}


A análise dos dados indica que, para substratos respiratórios do complexo I, haveria uma abundância $40 \%$ maior de NAD na cepa 115 em relação à cepa $C L$ Brener $(p=0,01)$ (Figura 22, painéis 1 e 2). Por outro lado, a abundância de NADH é 36\% maior na cepa CL Brener (Figura 22, painel 3). Em presença de succinato, a abundância relativa de NAD total e de $\mathrm{NAD}^{+}$mitocondrial é similar nas duas cepas $(p=0,055)$ (Figura 22, painéis 4 e 5). Estimamos uma abundância $\sim 60 \%$ maior ( $p=$ 0,002) de NADH mitocondrial na cepa CL Brener em relação a 115 (Figura 22, painel 6). Estas observações sugerem um fluxo reverso de elétrons no complexo II na cepa $\mathrm{CL}$ Brener com a conseqüente redução do $\mathrm{NAD}^{+}$para $\mathrm{NADH}$.

Os resultados obtidos também sugerem que, contrariamente ao que está descrito na literatura (TURRENS, 1989), Antimicina A inibe o complexo III de respiração.

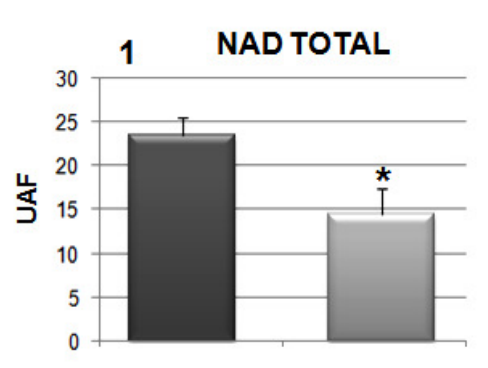

\section{Substratos complexo I}
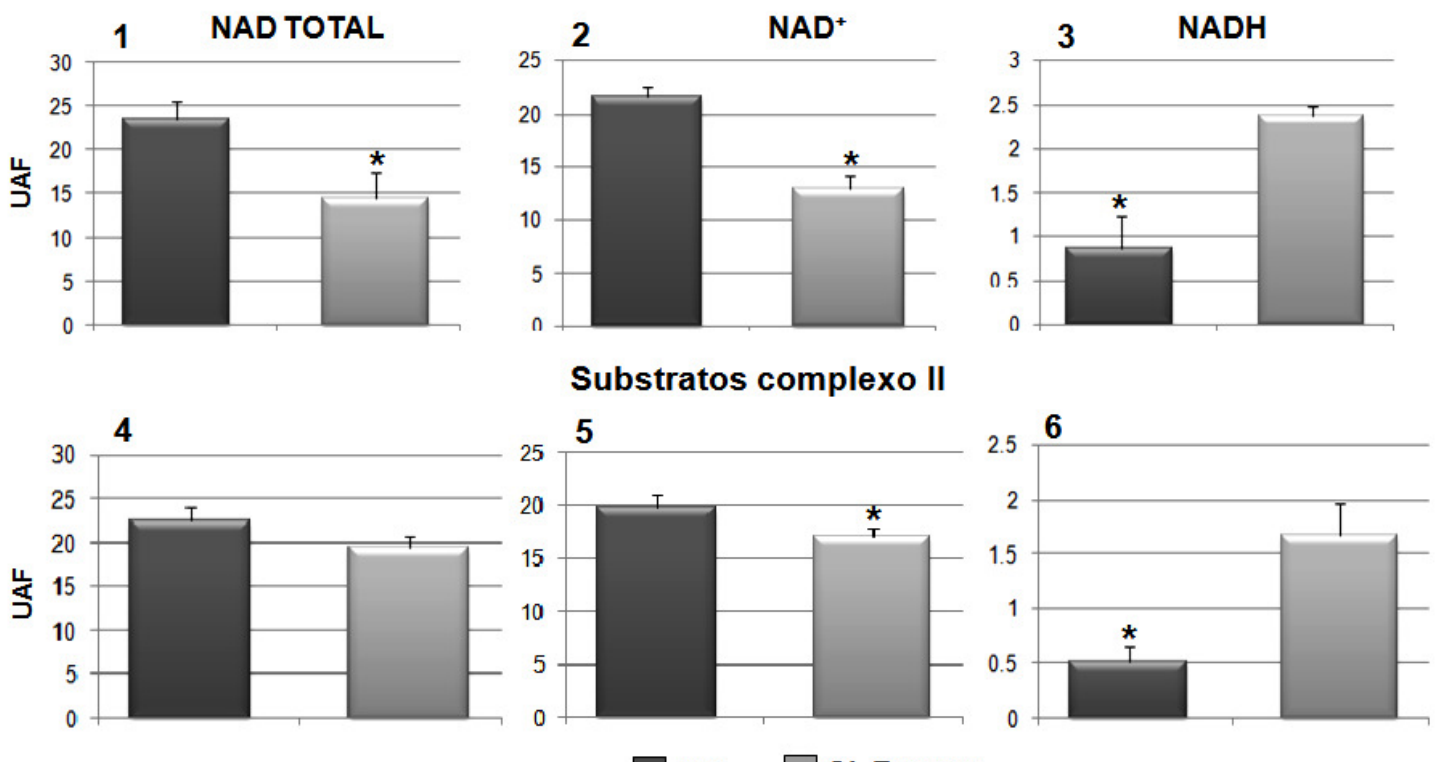

$115 \square$ CL Brener

Figura 22. Diferenças na abundância de NAD mitocondrial nas cepas 115 e CL Brener. $\left({ }^{*} p<0,05\right)$. 


\subsection{SENSIBILIDADE DE ISOLADOS HUMANOS A PERÓXIDO DE HIDROGÊNIO}

Para verificar se os isolados de $T$. cruzi apresentam diferenças de sensibilidade a $\mathrm{H}_{2} \mathrm{O}_{2}$ exógena, aplicaram-se os métodos descritos por Goyal et al. (1996) e Carnieri et al. (1993) com as modificações descritas em Material e Métodos. A exposição de epimastigotas a concentrações crescentes de $\mathrm{H}_{2} \mathrm{O}_{2}$ durante uma hora indica que a mobilidade e sobrevivência dos parasitas apresenta um declínio gradual com o aumento da dose do reagente. Para todas as cepas analisadas, em $160 \mu \mathrm{M}$ de $\mathrm{H}_{2} \mathrm{O}_{2}$, a porcentagem de mortalidade é superior a $99 \%$ em uma hora de incubação (dados não mostrados). Foram realizados três experimentos independentes, variando-se a concentração de $\mathrm{H}_{2} \mathrm{O}_{2}$ de 40 a $160 \mu \mathrm{M}$. Em cada experimento foi calculada a $\mathrm{Cl}_{50}$ que corresponde à concentração de $\mathrm{H}_{2} \mathrm{O}_{2}$ que inibe $50 \%$ da viabilidade dos parasitas (Tabela 11). Na Tabela apresenta-se ainda a média e dp dos valores de $\mathrm{Cl}_{50}$ de cada cepa. Observa-se que a sensibilidade varia de 76 a $120 \mu \mathrm{M}$ de $\mathrm{H}_{2} \mathrm{O}_{2}$ e que não existe uma correlação entre o grau de sensibilidade e a fase da doença de Chagas ou apresentação clínica na qual os parasitas foram isolados.

Tabela 11. Sensibilidade de isolados de T. cruzi a peróxido de hidrogênio. Valores de $\mathrm{Cl}_{50}$

\begin{tabular}{c|c|c|c|c|c}
\hline \hline \multirow{2}{*}{ Isolado } & \multirow{2}{*}{ Fase/Forma } & \multicolumn{3}{|c|}{ Experimento $^{\mathrm{a}}\left(\mu \mathrm{M} \mathrm{H}_{2} \mathrm{O}_{2}\right)^{\mathrm{b}}$} & \multirow{2}{*}{$\mathrm{Cl}_{50}$} \\
\cline { 3 - 5 } & & 1 & 2 & 3 & \\
\cline { 3 - 5 } Berenice 62 & $\mathrm{CR} / \mathrm{ASS}$ & 77,5 & 77,8 & 80,5 & $78,6 \pm 1,6$ \\
\hline Yuyu & $\mathrm{NA}$ & 78,5 & 74,32 & 73,75 & $75,52 \pm 2,6$ \\
\hline 003B & $\mathrm{CR} / \mathrm{ASS}$ & 77,6 & 72,04 & 78,2 & $75,94 \pm 3,4$ \\
\hline VL10 & $\mathrm{CR} / \mathrm{ASS}$ & 76 & 89,6 & 80 & $81,86 \pm 6,9$ \\
\hline Famema & $\mathrm{CR} / \mathrm{ASS}$ & 85,81 & 92 & 93,6 & $90,47 \pm 4,1$ \\
\hline Silvio & $\mathrm{AG}$ & 94,24 & 96,9 & 98,99 & $96,71 \pm 2,3$ \\
\hline Esmeraldo & $\mathrm{AG}$ & 101,9 & 101 & 101,5 & $101,5 \pm 0,6$ \\
\hline Colombiana & $\mathrm{CR} / \mathrm{ASS}$ & 103,3 & 101,04 & 102,98 & $102,44 \pm 1,2$ \\
\hline Berenice 78 & $\mathrm{CR} / \mathrm{ASS}$ & 106,7 & 105,8 & 105,6 & $106 \pm 0,6$ \\
\hline 115 & $\mathrm{CR} / \mathrm{CCC}$ & 106,9 & 108,8 & 106,9 & $107,85 \pm 1,1$ \\
\hline $\mathrm{Y}$ & $\mathrm{AG}$ & 108,8 & 109 & 106,5 & $108,1 \pm 1,4$ \\
\hline CL Brener & $\mathrm{NA}$ & 110 & 108,6 & 110 & $109,5 \pm 0,7$ \\
\hline B-147 & $\mathrm{CR} / \mathrm{CCC}$ & 111,6 & 112,7 & 109,2 & $111,16 \pm 1,7$ \\
\hline B13-167 & $\mathrm{CR} / \mathrm{CCC}$ & 111,1 & 114,6 & 112,9 & $112,86 \pm 1,8$ \\
\hline 0050F & $\mathrm{CR} / \mathrm{ASS}$ & 118,65 & 121,7 & 116,87 & $119,07 \pm 2,4$ \\
\hline \hline
\end{tabular}

aare: CR, crônica; AG; aguda; Forma: ASS, assintomática; CCC, cardiomiopatia chagásica. NA, não aplica.

${ }^{b}$ Concentração de $\mathrm{H}_{2} \mathrm{O}_{2}$ que inibe a viabilidade dos parasitas em $50 \%$ 
Na Figura 23 apresentam-se os resultados dos valores da média \pm dp dos $\mathrm{Cl}_{50}$. As cepas foram divididas arbitrariamente em duas classes: cepas que apresentaram $\mathrm{Cl}_{50}<95 \mu \mathrm{M}$ foram consideradas sensíveis (Berenice 62, Yuyu, 003B, VL10 e Famema), e as demais (Silvio, Esmeraldo, Colombiana, Berenice 78, 115, Y, CL Brener, B147, B13-167 e 0050F) foram consideradas resistentes. A análise da diferença das médias da $\mathrm{Cl}_{50}$ das duas classes, mediante o teste t-Student, sugere que os dois grupos são significativamente diferentes $\left(p=2,66^{-6}\right)$.

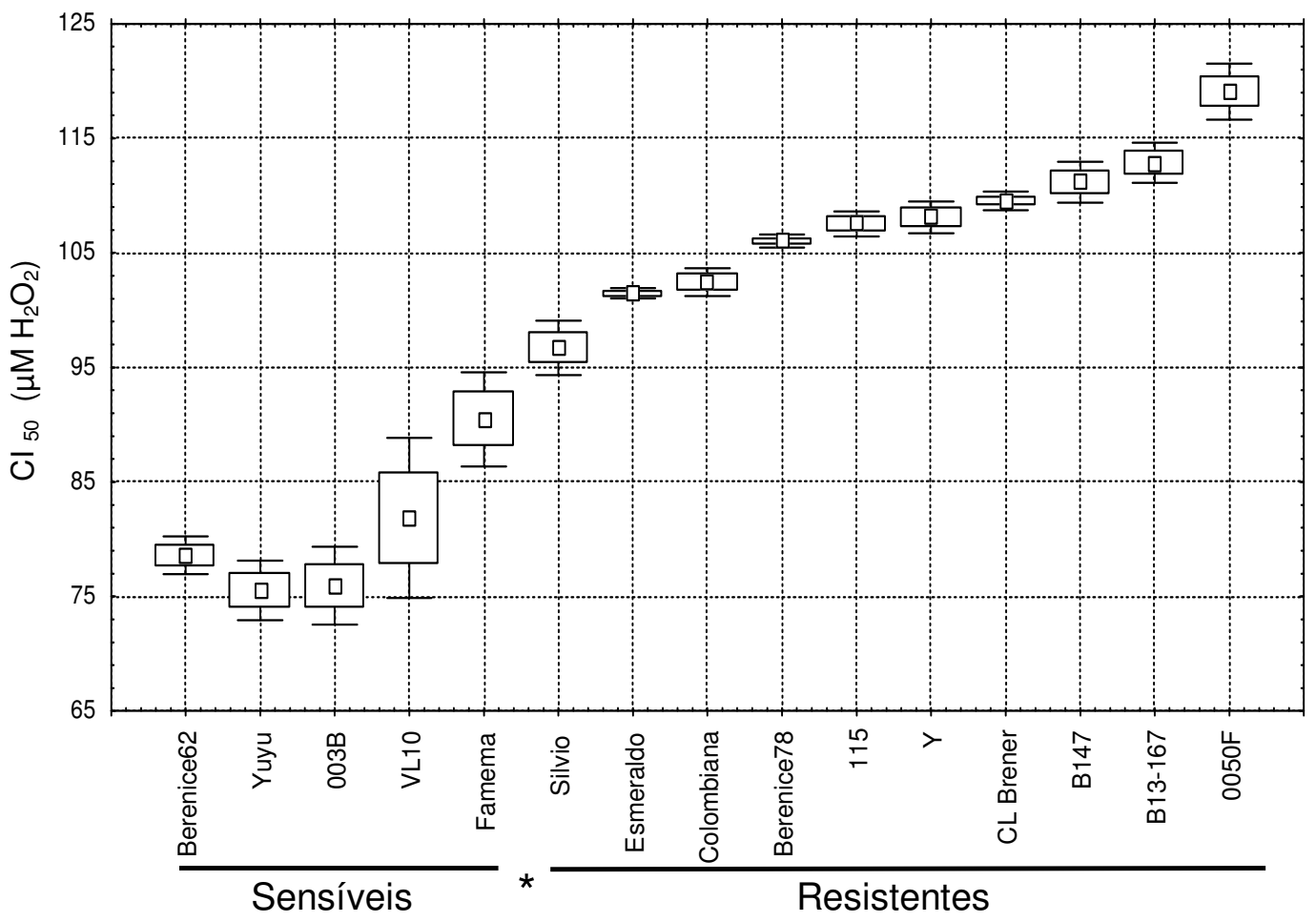

Figura 23. Distribuição das cepas de $T$. cruzi em duas classes de acordo com sua sensibilidade a $\mathrm{H}_{2} \mathrm{O}_{2}$. ${ }^{*} p<0,05$.)

\subsection{NÍVEIS DE TRANSCRITOS DE GENES PUTATIVAMENTE ENVOLVIDOS NA DETOXIFICAÇÃO DE EROs}

Num estudo desenvolvido por Margoth Moreno em nosso laboratório, utilizando a tecnologia de microarranjos de DNA, foram observadas diferenças na transcrição de alguns genes do sistema da tripanotiona e genes que codificam 
superóxido dismutases A (SOD-A) nas cepas 115 (resistente a $\mathrm{H}_{2} \mathrm{O}_{2} ; \mathrm{Cl}_{50}$ 107,85 \pm $1,1 \mu \mathrm{M}$ ) e VL10 (sensível a $\mathrm{H}_{2} \mathrm{O}_{2} ; \mathrm{Cl}_{50} 81,86 \pm 6,9 \mu \mathrm{M}$ ). Na Tabela 12 apresenta-se o número de acesso dos genes em questão e a razão de hibridização entre as cepas (Margoth Moreno, comunicação pessoal ${ }^{1}$ ).

Com o objetivo de analisar uma possível correlação entre a sensibilidade a $\mathrm{H}_{2} \mathrm{O}_{2}$ exógena e a transcrição diferencial desses genes, quantificamos os níveis dos transcritos em ambas as cepas em ensaios de RT-PCR em tempo real. A abordagem experimental está descrita em Material e Métodos. O gene da GAPDH foi usado como controle interno ou normalizador da quantidade da amostra. Os dados apresentados na Tabela 12 indicam que os níveis de transcritos da tripanotiona sintetase são maiores na cepa VL10, ao passo que os níveis de transcritos da SOD- $A^{1}$ são maiores na cepa 115 , concordando com os resultados dos microarranjos. Por outro lado, não observamos diferenças na abundância dos transcritos da SOD- $\mathrm{A}^{2}$ nas duas cepas, e ainda verificamos maior quantidade de transcritos de triparedoxina peroxidase na cepa 115. O aumento de transcritos de SOD-A ${ }^{1}$ na cepa 115 poderia explicar a maior geração de peróxido de hidrogênio mitocondrial (ver Tabela 9).

Tabela 12. Razão de hibridização dos CDNA das cepas VL10 e 115 e da abundância de transcritos.

\begin{tabular}{|c|c|c|c|c|c|}
\hline \multirow{2}{*}{ Gene } & \multirow{2}{*}{ GenBank } & \multicolumn{2}{|c|}{$\begin{array}{l}\text { Razão de hibridização nos } \\
\text { microarranjos }^{a}\end{array}$} & \multicolumn{2}{|c|}{$\begin{array}{c}\text { Razão da abundância de } \\
\text { transcritos }^{\mathrm{b}}\end{array}$} \\
\hline & & VL10/115 & 115/VL10 & VL10/115 & 115/VL10 \\
\hline $\begin{array}{c}\text { Triparedoxina peroxidase } \\
\text { Citossólica }\end{array}$ & XM_803661.1 & 2,8 & -- & 0,5 & -- \\
\hline Tripanotiona sintetase & XM_814378.1 & 4,0 & -- & 3,7 & -- \\
\hline SOD-A ${ }^{1}$ & XP_804176.1 & -- & 5,5 & -- & 3,8 \\
\hline SOD-A ${ }^{2}$ & XM_805945.1 & -- & 7,5 & -- & 1 \\
\hline
\end{tabular}

${ }^{a}$ Dados obtidos por Margoth Moreno.

${ }^{\mathrm{b}}$ Dados obtidos por RT-PCR em tempo real

${ }^{1}{ }^{2}$ Isoformas mitocondriais de Fe-SOD-A

\footnotetext{
${ }^{1}$ Moreno, M. M. V. São Paulo, 2008 (comunicação pessoal).
} 
Nos experimentos subseqüentes (Tabela 13) determinamos os níveis relativos de transcritos dos quatro genes em 8 cepas adicionais, cuja sensibilidade a peróxido de hidrogênio havia sido determinada (ver Tabela 11). Para efeito comparativo, os dados foram normalizados tomando-se como referência a cepa Berenice 62, uma das cepas mais sensíveis ao reagente (ver Tabela 11). Os dados são mostrados na Figura 24, onde as cepas estão divididas nas duas classes definidas acima.

Tabela 13. Abundância relativa de transcritos de quatro genes

\begin{tabular}{c|c|c|c|c}
\hline Cepas Genes & $\begin{array}{c}\text { Triparedoxina } \\
\text { peroxidase } \\
\text { Citossólica }\end{array}$ & $\begin{array}{c}\text { Tripanotiona } \\
\text { sintetase }\end{array}$ & SOD-A ${ }^{1}$ & SOD-A $^{2}$ \\
\hline Berenice 62 & 1 & 1 & 1 & 1 \\
\hline 003b & 0,35 & 0,81 & 0,7 & 0,6 \\
\hline VL 10 & 0,38 & 0,93 & 0,72 & 1,05 \\
\hline Yuyu & 0,6 & 0,16 & 0,3 & 0,024 \\
\hline Silvio & 0,67 & 0,018 & 0,57 & 0,01 \\
\hline Esmeraldo & 0,36 & 0,36 & 1 & 0,9 \\
\hline Colombiana & 0,87 & 0,14 & 1,97 & 0,05 \\
\hline 115 & 0,62 & 0,25 & 2,75 & 1,05 \\
\hline CL Brener & 0,57 & 0,42 & 0,7 & 0,36 \\
\hline 050F & 0,45 & 0,25 & 0,58 & 1,0 \\
\hline \hline
\end{tabular}

NOTA: A linha em negrito separa as duas classes de cepas: acima da lihna, sensíveis, abaixo da linha, resistentes.

Para verificar se algum dos genes apresenta diferenças significativas nos níveis de transcritos entre cepas resistentes e sensíveis a peróxido de hidrogênio, submetemos os dados ao teste estatístico de $t$-Student que avalia as diferenças das médias entre dois grupos amostrais pequenos. $O$ teste foi aplicado com um nível de confiança de 95\% para aceitar a hipótese nula (H0: não existe diferença de expressão significativa do gene entre ambos os grupos). A diferença foi considerada significativa quando o valor $p$ era menor que 0,05 (Figura 25). Observa-se uma diferença significativa na abundância dos transcritos do gene da Tripanotiona Sintetase nas cepas sensíveis a $\mathrm{H}_{2} \mathrm{O}_{2}(p=0,012)$, porém o mesmo não foi observado 
quanto aos genes para Triparedoxina peroxidase $(p=0,96), \operatorname{SOD}^{1} \quad(p=0,25)$ e SOD- $A^{2}(p=0,73)$. Por outro lado, o padrão geral dos níveis relativos dos transcritos nas cepas (Figura 24) sugere que as variações sejam uma característica intrínseca de cada cepa, em contraposição a um padrão específico das classes sensível e resistente a peróxido de hidrogênio.
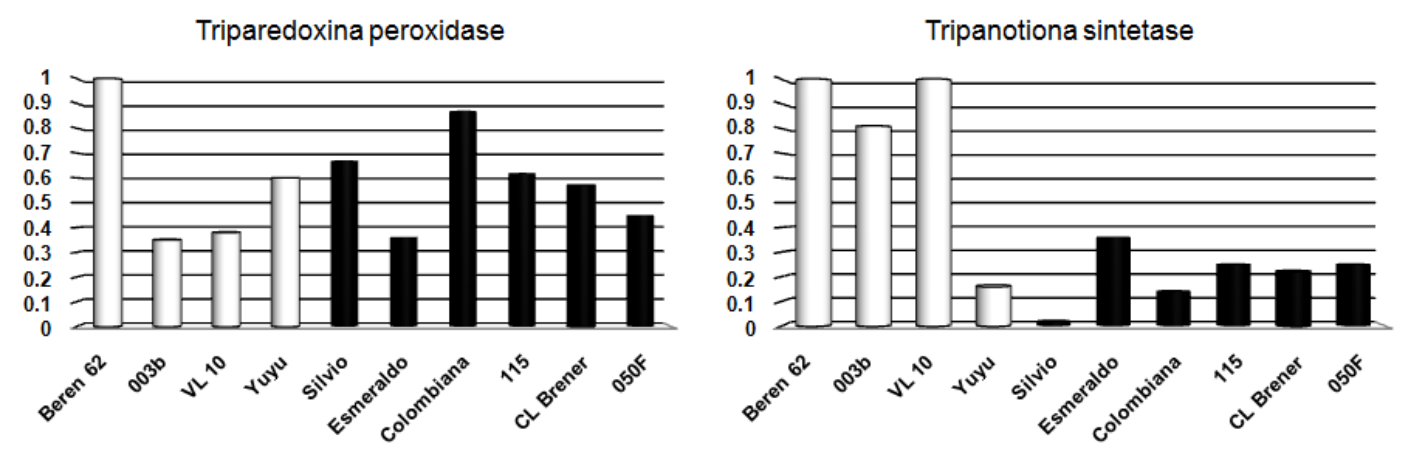

FeSOD-A 1

FeSOD-A
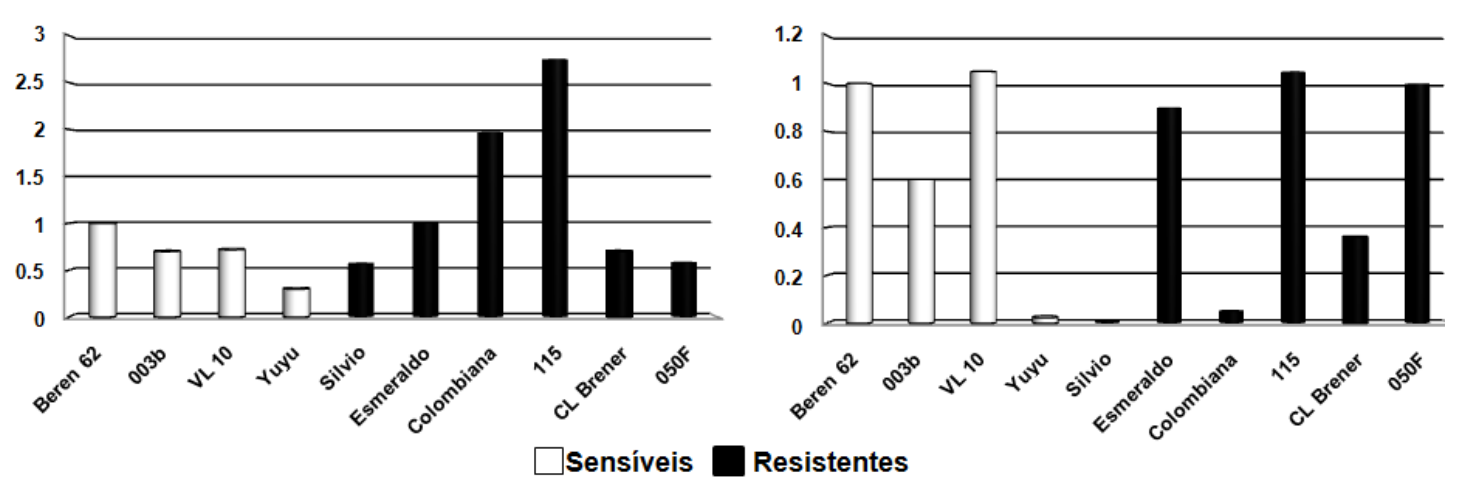

Figura 24. Abundância relativa de transcritos de quatro genes em cepas de $T$. cruzi. A cepa Berenice 62 foi usada como normalizador dos dados. 

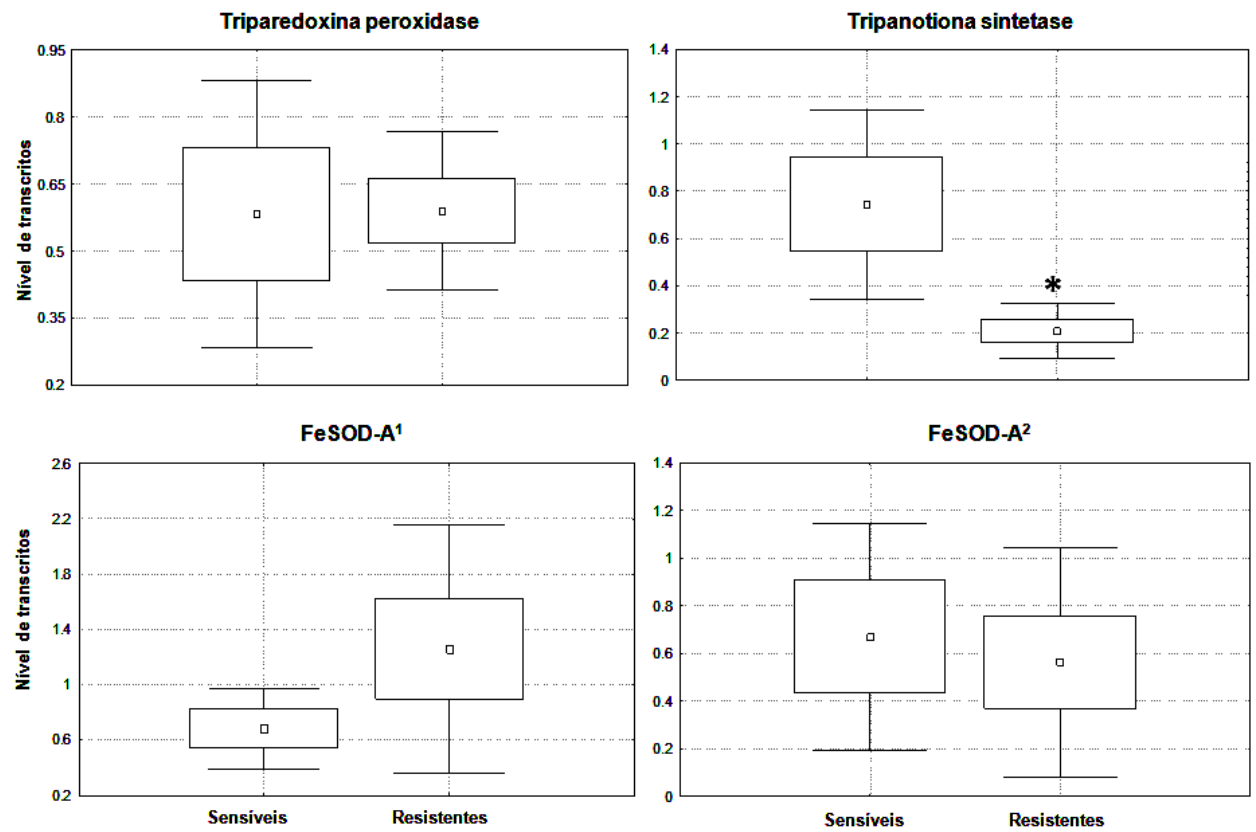

Figura 25. Comparação das médias da abundância relativa de transcritos de quatro genes nos dois grupos de cepas de $T$. cruzi. $\left({ }^{*} p<0,05\right)$. 


\section{DISCUSSÃO}

A infecção humana com $T$. cruzi gera um espectro de manifestações clínicas e uma ampla gama de sintomas. As causas do pleomorfismo da doença de Chagas permanecem desconhecidas. No entanto, quase certamente, dependem da interação multifatorial entre o hospedeiro humano e o parasita (TARLETON, 2001; MACEDO et al., 2004; CAMPBELL et al., 2004). Os determinantes do hospedeiro que influenciariam o desfecho da infecção incluem fatores genéticos, geográficos e sociais. Os determinantes do parasita incluiriam fatores que determinam a virulência, tropismo tissular, resistência ao estresse oxidativo e escape do sistema imune.

$\mathrm{Na}$ tentativa de identificar genes diferencialmente expressos em isolados de pacientes com CCC e ASS, foi empregada a tecnologia de microarranjos de DNA. A sonda que revelou a maior expressão diferencial entre as duas classes de isolados correspondia àquela que codifica a subunidade 7 da NADH desidrogenase (ND7) ou complexo I de respiração mitocondrial (BAPTISTA et al., 2006). De fato, observamos que os transcritos deste gene em isolados de CCC eram cerca de 30 vezes mais abundantes em relação aqueles de isolados de ASS. Esta observação sugeriu que o gene ND7 poderia ser um alvo interessante para o diagnóstico diferencial das duas classes de isolados, com possível aplicação no prognóstico da evolução da doença.

\subsection{ESTRUTURA DO GENE ND7}

A amplificação e seqüenciamento do gene ND7 nos isolados de $T$. cruzi revelou uma deleção de aproximadamente 455 pb na região central do gene de cepas de pacientes ASS, cuja localização é conservada entre as cepas. Esta deleção resulta em um mRNA de $500 \mathrm{nt}$, que é cerca de $50 \%$ menor em relação ao mRNA de isolados de pacientes com CCC (BAPTISTA et al., 2006). A sonda aplicada nos microarranjos cobria praticamente toda a região da deleção, o que explica o resultado observado referente à transcrição diferencial deste gene nos isolados das duas classes de pacientes.

Nos estudos de amplificação do gene ND7, chama a atenção o consistente dimorfismo encontrado entre os isolados. De fato, apenas dois tipos de produtos 
foram observados em mais de 100 cepas analisadas: 500 pb e 900 pb. A conservação da deleção em ND7 sugere que este seja um evento antigo e que as cepas que apresentam esta mutação tenham se originado de um ancestral comum. A análise da estrutura de ND7 em cepas dos grupos T. cruzi I, T. cruzi II, rDNA 1/2 e zimodema 3 indica que a deleção é encontrada apenas em algumas cepas de $T$. cruzi II. Por outro lado, verificamos que duas cepas T. cruzi II, subgrupo DTU Ilb (Esmeraldo e Y) apresentam diferentes amplicons: Esmeraldo, 900 pb e Y, 500 pb, sugerindo que a deleção tenha ocorrido num ancestral pertencente a este subgrupo (BAPTISTA et al., 2006). No presente estudo, confirmamos esta hipótese após analisarmos mais de 70 isolados de pacientes portadores da doença de Chagas, todos caracterizados como pertencentes a T. cruzi II pela amplificação do domínio D7 do gene de rRNA 24S $\alpha$, e pertencentes à DTU Ilb, via caracterização do haplogrupo mitocondrial (ver manuscrito em preparação anexo).

\subsection{ESTRUTURA DE OUTROS GENES MITOCONDRIAIS}

Com o objetivo de verificar se haveria modificações estruturais em outros genes localizados no maxicírculo de T. cruzi, padronizamos ensaios de PCR para amplificar o gene COIII, contíguo a ND7, e o gene ND4, que codifica a subunidade 4 do complexo I. No gene ND4 da cepa Esmeraldo foi descrita uma deleção de 236 pb de sua região 5', bem como da região 5' do gene CR4 e região intergênica (WESTENBERGER et al., 2006). A análise de cerca de 40 isolados de T. cruzi provenientes de humanos e vetores mostrou que o gene COIII apresenta uma estrutura conservada. Por outro lado, para o gene ND4 também verificamos um dimorfismo nos amplicons obtidos, que sugerem a conservação da deleção observada. Assim como para o gene ND7, observamos que a deleção em ND4 está presente em alguns isolados de DTU Ilb. Em algumas cepas, não foi possível amplificar os genes COIII e ND4 muito provavelmente por haver variação de seqüência nas regiões onde os iniciadores da PCR hibridizam.

Westenberger et al. (2006) verificaram que a cepa Esmeraldo também apresenta três mutações que alteram a fase de leitura do gene ND5, que acarretariam uma proteína truncada de 165 aminoácidos comparada com o produto 
de 589 aminoácidos em CL Brener. Os autores sugerem que a presença de deleções nos genes CR4, ND4 e ND5 na cepa Esmeraldo pode ser um evento recente, tolerado em cepas cultivadas em laboratório, mas deletéria em populações silvestres e incompatível com processos de virulência. No entanto, no presente estudo, verificamos a deleção em ND4 em isolados recentes de pacientes ASS e com CCC, o que indica que as cepas se mantêm viáveis e conservam sua capacidade infectante.

Uma pergunta que pode ser formulada é se as mutações observadas nos genes dos maxicírculos estão relacionadas com processos de edição dos transcritos. No entanto, seja o gene ND4 como o gene ND5 não são editados em $T$. cruzi, (WESTENBERGER et al., 2006) ou em outros tripanossomatídeos como T. brucei e L. tarentolae (ALFONZO et al., 1997). Por outro lado, o gene ND7, que apresenta deleção e o gene COIII, onde não observamos alteração de estrutura, são editados. COIII é o gene mais extensamente editado em $T$. cruzi e em vários outros tripanossomatídeos (ALFONZO et al., 1997). Em T. brucei, por exemplo, 57\% da seqüência do transcrito de COIIl é composta de uridinas que são adicionadas por edição do RNA (KOSLOWSKY et al., 1990; WESTENBERGER et al., 2006).

No manuscrito anexo também são mostradas mutações pontuais no gene COII, que geram sítios de restrição para a enzima Alul e que permitem sua tipagem em haplogrupos mitocondriais (FREITAS et al., 2006).

O conjunto de dados indica que mutações do tipo deleção são observadas em pelo menos três genes que codificam subunidades da NADH desidrogenase mitocondrial: ND4, ND5 e ND7, e que as cepas que apresentam estas deleções mantêm suas características biológicas.

\subsection{VALIDAÇÃO DA REAÇÃO DIAGNÓSTICA DE PCR PARA ND7 EM ISOLADOS HUMANOS}

Apesar de vários estudos terem buscado marcadores moleculares visando correlacionar a variabilidade genética dos parasitas com as características clínicas da doença de Chagas, os resultados foram infrutíferos (MOREL et al., 1980; MACEDO et al., 1992; VAGO et al., 2000). Os dados preliminares obtidos por nós 
(BAPTISTA et al., 2006) sugeriam que o gene ND7 poderia ser utilizado em ensaios de PCR para o diagnóstico da cepa infectante e possível prognóstico da manifestação clínica dos pacientes.

Para validar esta hipótese, no presente estudo, analisamos a estrutura do gene ND7 em isolados de 75 pacientes com sorologia positiva para a doença de Chagas. Estes pacientes participam de um estudo prospectivo não randomizado para avaliar o impacto do tratamento com benznidazol na evolução da doença de Chagas, conduzido desde 1997 por pesquisadores do Hospital das Clínicas da Faculdade de Medicina da UFMG (ver manuscrito anexo). Na amostra que estudamos, 56 pacientes (74,6\%) apresentavam a forma indeterminada e 19 $(25,3 \%)$, CCC. Esta distribuição segue, em linhas gerais, dados epidemiológicos brasileiros, que mostram prevalência de cerca de $70 \%$ da forma indeterminada e de $30 \%$ da forma cardíaca (WHO, 2002; PRATA, 2001). A predominância de mulheres na amostra $(58,6 \%)$ é justificada pelo fato de o estudo ser não-randomizado e direcionado para pacientes atendidos em hospitais e ambulatórios. Neste caso, sempre há predomínio de mulheres, por serem mais preocupadas com a saúde e terem maior disponibilidade de tempo para as consultas. Além disto, as mulheres concordam mais em participar de estudos do que homens (Dra. Eliane Gontijo, comunicação pessoal ${ }^{2}$ ). Finalmente, deve ser lembrado que, no projeto acima referido, o tratamento com benznidazol era oferecido para pacientes com a forma indeterminada ou forma cardíaca leve (Dra. Eliane Gontijo, comunicação pessoal ${ }^{2}$ ). Esta pode ser uma limitação do estudo onde não estão incluídos pacientes com CCC grave.

A estrutura do gene ND7 foi avaliada com o ensaio de PCR descrito acima. Nos isolados de pacientes ASS, obtivemos o produto de $\sim 500 \mathrm{pb}$ em $46,4 \%$ das amostras; o produto de $\sim 900 \mathrm{pb}$ em $44,6 \%$ das amostras e ambos os produtos em $8,9 \%$ dos isolados. Para os isolados de pacientes com CCC, observamos que $42 \%$ apresentaram o produto de $\sim 900 \mathrm{pb}$ e $58 \%$ o produto de $\sim 500 \mathrm{pb}$.

De acordo com nossa hipótese de trabalho, os indivíduos ASS que albergam isolados que geram produtos de ND7 de $\sim 900$ pb estariam sob risco potencial de desenvolver futuras cardiopatias. Esta suposição poderia explicar a presença deste amplicon em $44,6 \%$ dos pacientes ASS. Se por um lado, verificamos que dois

\footnotetext{
${ }^{2}$ Gontijo, E. Belo Horizonte, 2008 (comunicação pessoal).
} 
pacientes ASS em 1999, com gene ND7 sem deleção, desenvolveram CCC em 2004 (um paciente) e 2006 (outro paciente) (ver manuscrito anexo), por outro, a história da doença de Chagas mostra que apenas cerca de $30 \%$ de indivíduos ASS desenvolve patologias no coração ou trato digestivo (PINTO DIAS et al., 2006). A presença da deleção em ND7 em 58\% dos isolados de indivíduos com CCC afasta completamente nossa hipótese. Curiosamente, observamos que dez pacientes dos onze que apresentam CCC e deleção no gene são do sexo feminino. Isto pode ser uma conseqüência da prevalência de mulheres (58,6\%) na amostra estudada. Por outro lado, foi observado que uma característica que diferencia a CCC de outras cardiomiopatias é sua predominância em pacientes do sexo masculino com idade entre 30 e 60 anos (RASSI et al., 2007). Desta forma, concluímos não haver uma correlação entre o tamanho do amplicon de ND7 e as manifestações clínicas da doença de Chagas.

Em cinco isolados de pacientes ASS obtivemos os dois amplicons de ND7, com predominância em alguns casos do produto de 900 pb. Este resultado poderia ser conseqüência da heterogeneidade dos maxicírculos na mesma população de parasitas ou da presença de sub-populações geneticamente diferentes na cepa infectante. De fato, tem sido documentado que o mesmo indivíduo pode estar infectado com mais de uma população de T. cruzi (MACEDO et al., 2004). Como exemplo, cita-se o caso da paciente Berenice, o primeiro caso humano de doença de Chagas, reportado por Carlos Chagas em 1909. Desta paciente foram isoladas duas cepas, uma em 1962, denominada Be-62 e outra em 1978, denominada Be-78. As duas cepas apresentam características biológicas, bioquímicas e moleculares diferentes. Ao contrário da cepa Be-62, a cepa Be-78 gera fibrose e lesões cardíacas em camundongos e cães (LANA e CHIARI, 1986; LANA et al., 1992). Além disto, foi verificado que as duas cepas apresentam padrões de microsatélites diferentes (CRUZ et al., 2006). O resultado da PCR para ND7 das duas cepas de Berenice mostrou que a cepa Be-62 apresenta a mutação no gene, enquanto a cepa Be-78 apresenta o gene normal. Uma interpretação para estas observações é que a paciente tenha sido infectada originalmente por mais de uma cepa, ou que tenha sido infectada em duas ou mais ocasiões com cepas diferentes. $O$ isolamento das duas cepas em ocasiões distintas pode ser reflexo da diferente abundância das populações circulantes no momento do isolamento. Outra possibilidade é que tenha 
ocorrido seleção de sub-populações durante a hemocultura e amplificação subseqüente. Além disto, foi mostrado que cepas circulantes podem ser diferentes das populações responsáveis pela lesão tissular (MACEDO et al., 2004).

Em alguns isolados, avaliamos também a estrutura dos genes COIII e ND4. Não observamos nenhuma correlação entre a presença da deleção em ND4 e a apresentação clínica da doença de Chagas. Esta conclusão também é válida para a estrutura do gene COII (ver manuscrito anexo). Desta forma, outros marcadores moleculares e/ou biológicos deverão ser pesquisados para comprovar se características do parasita determinam a patologia da doença.

O desenvolvimento de CCC em apenas um terço dos indivíduos infectados com T. cruzi e a tendência da agregação familiar da doença (ZICKER et al., 1990) sugere que fatores genéticos do hospedeiro humano estejam envolvidos em tal suscetibilidade. Variações nos loci A, B e C de HLA classe II têm sido implicados na suscetibilidade para a doença de Chagas ou na progressão para a forma severa da cardiopatia (CAMPBELL et al., 2004). Na população brasileira não foi encontrada associação entre o risco de desenvolver CCC e dois genes de HLA de classe 2 (HLA-DR e HLA-DQ) (MACHADO et al., 2000). A análise de polimorfismos na região promotora do gene TNF-alfa mostrou não haver associação com o risco de desenvolver CCC em pacientes do Peru (ROVIN et al., 1999), ao contrário do que foi observado com populações mexicanas (KRUGER et al., 2002).

O grupo do Dr. Edécio Cunha Neto (FM-USP) tem estudado a regulação da produção de citocinas na doença de Chagas crônica. Foi observado que citocinas inflamatórias e quimiocinas, importantes mediadores inflamatórios, estão aumentadas na CCC. Linfócitos encontrados no coração de pacientes com CCC também expressam citocinas pró-inflamatórias do tipo IFN-gama e TNF-alfa (REIS et al., 1993, 1997; ABEL et al., 2001). Mais recentemente, foram descritos dois polimorfismos (-22G/C e -348C/T) na região promotora do gene $B A T-1$, membro da família $D E A D$-box e considerado um gene potencial anti-inflamação, que estariam associados ao desenvolvimento da CCC. Este gene, localizado na região central do complexo maior de histocompatibilidade (MHC), reprime a expressão do fator TNFalfa e da IL-6 (TEIXEIRA et al., 2002). Em pacientes brasileiros, foi verificado que indivíduos homozigotos para a variante $-22 \mathrm{C}$ apresentam um risco 5 vezes maior de 
desenvolver CCC e que indivíduos homozigotos para o alelo $-348 \mathrm{C}$, um risco 2 vezes maior (RAMASAWMY et al., 2006).

As observações acumuladas até o momento sugerem que a progressão para a doença de Chagas crônica é um processo complexo que depende da combinação de fatores genéticos do parasita, do hospedeiro e ambientais.

\subsection{FUNCIONALIDADE DO COMPLEXO I MITOCONDRIAL}

Conforme especificado na Introdução, a atividade/funcionalidade do Complexo I nos tripanossomatídeos é um tema muito debatido. Uma revisão recente aborda este tópico em profundidade (OPPERDOES e MICHELS, 2008).

O metabolismo energético em tripanossomatídeos patogênicos - T. brucei, $T$. cruzi e Leishmania e no tripanossomatídeo de plantas, Phytomonas serpens, vem sendo bem estudado há muito tempo (BRINGAUD et al., 2006). Uma vez que meios ricos em glicose são utilizados rotineiramente para cultivar estes organismos, o metabolismo de carboidratos é bem conhecido, ao passo que pouco se conhece a respeito do metabolismo de aminoácidos e ácidos graxos. A maior parte dos dados recentes refere-se a enzimas envolvidas em vias metabólicas de T. brucei, uma vez que neste organismo é possível utilizar a metodologia de RNA de interferência (RNAi) para silenciar especificamente a expressão de um gene alvo. Lamentavelmente, esta metodologia não pode ser aplicada em $T$. cruzi e algumas espécies de Leishmania, uma vez que nestes organismos enzimas do sistema RNAi estão ausentes. Além disto, há muito poucos relatos de obtenção de mutantes em tripanossomatídeos.

Como foi descrito na Introdução, uma vez que os tripanossomatídeos apresentam uma mitocôndria única, para se estudar os processos bioenergéticos que nela ocorrem, é necessário realizar uma permeabilização seletiva da membrana plasmática com digitonina. A concentração de digitonina a ser utilizada deve ser cuidadosamente padronizada, conforme demonstrado por Rodrigues et al. (2001), já que diferenças na composição dos meios de cultura podem gerar diferenças significativas na suscetibilidade a este detergente. Em nossos estudos, empregamos uma concentração de digitonina de $64 \mu \mathrm{M}$, que promove um $\mathrm{CR} \geq 2,0$. Isto indica que 
nas células permeabilizadas a mitocôndria se encontra intacta e a função mitocondrial está acoplada. Esta concentração de digitonina concorda com aquela utilizada por Docampo e Vercesi (1989); Vercesi et al. (1991); Rodrigues et al. (2001) e Piacenza et al. (2007).

Isolados que apresentam deleção nos genes ND7 e ND4 representam mutantes naturais que podem ser utilizados no estudo da funcionalidade do complexo I, seja no que diz respeito ao processo de fosforilação oxidativa mitocondrial, seja na produção de EROs na mitocôndria. No presente estudo, alguns parâmetros do funcionamento da mitocôndria foram investigados em algumas cepas de T. cruzi portadoras ou não de mutações nos dois genes. Não observamos diferenças significativas nos valores do CR utilizando substratos para o complexo I ou complexo II de respiração nas cepas CL Brener e 115 (que apresentam o gene ND7 normal), cepas VL10 e Famema (gene ND7 com deleção) e cepa Esmeraldo (gene ND4 com deleção). Estes resultados poderiam indicar que as deleções nos genes ND7 e ND4 não afetam a atividade do complexo I. Por outro lado, também poderiam indicar que o complexo I não é (ou é pouco) funcional em $T$. cruzi e que o NADH formado a partir dos substratos malato e piruvato seria oxidado por outra via.

Nos tripanossomatídeos, succinato é o produto final do metabolismo da glicose. As vias metabólicas que levam à produção de succinato são bem conhecidas (CAZZULO, 1992; BRINGAUD et al., 2006). Sabe-se que fumarato pode ser reduzido a succinato pelas enzimas $\mathrm{NADH}$-fumarato redutases (FRD) glicossomais e mitocondriais. Desta forma, a FRD glicossomal seria responsável pela oxidação do NADH produzido na glicólise. A fermentação succínica também ocorre na mitocôndria, embora seu papel na manutenção do balanço redóx desta organela seja debatido em função da presença do complexo I ligado à cadeia de transporte de elétrons (BRINGAUD et al., 2006). Em nosso estudo, para avaliar se o NADH gerado pelos substratos malato e piruvato é oxidado pelo complexo I, ou é oxidado pela $\mathrm{NADH}$-fumarato redutase, determinamos a velocidade de consumo de oxigênio e o CR em presença ou ausência de malonato na concentração de $10 \mathrm{mM}$, inibidor do complexo II.

Para as duas cepas investigadas, CL Brener, com gene ND7 normal e VL10, com gene ND7 com deleção, verificamos uma inibição do consumo de oxigênio no Estado III, em presença de substratos de complexo I (piruvato e malato) ou II 
(succinato), da ordem de 50 a 60\%. Inibição análoga foi observada nos valores do CR nas duas cepas. A inibição do consumo de oxigênio em presença de succinato comprova que, de fato, malonato está inibindo o complexo II. Além desto, a inibição do consumo de oxigênio com substratos de complexo I na mesma extensão da inibição observada com o substrato de complexo II sugere que NADH seria oxidado total ou parcialmente pela fumarato redutase, originando succinato, o qual seria então oxidado via complexo II. De fato, vários pesquisadores propõem que a cadeia respiratória dos tripanossomatídeos estaria adaptada para a oxidação de succinato no lugar de NADH (TURRENS, 2003; CAZZULO, 1994; COUSTOU et al., 2006).

Nestes experimentos chama a atenção o fato de o malonato, na concentração de $10 \mathrm{mM}$, ter promovido uma inibição de apenas 50-60\%. Esta concentração de malonato é utilizada nos ensaios de inibição de complexo II em células de outros eucariotos. De fato, em extratos mitocondriais de células musculares de rato foi relatado que a constante de inibição $\left(\mathrm{K}_{\mathrm{i}}\right)$ por malonato é da ordem de $34 \mu \mathrm{M}$ (NAKAE e SHONO, 1986). Em ensaios de caracterização de funções mitocondriais de $T$. brucei, as concentrações de malonato utilizadas foram $10 \mathrm{mM}$ (BEATTIE e HOWTON, 1996; COUSTOU et al., 2008) ou 5 mM (TURRENS, 1989). Nestes ensaios, no entanto, não foi determinada a porcentagem de inibição da atividade do complexo II. É possível que em tripanossomatídeos a constante de inibição do malonato seja diferente daquela observada nos demais eucariotos.

Nos estágios de $T$. cruzi encontrados no inseto e nos amastigotas intracelulares, os aminoácidos, principalmente prolina, ácido aspártico e ácido glutâmico, constituem a principal fonte de carbono e energia (SILBER et al., 2005). Estes aminoácidos são processados via ciclo de Krebs, que necessita de NAD oxidado para seu funcionamento. Uma NADH desidrogenase alternativa, que contém FMN e que é insensível a rotenona, foi caracterizada na mitocôndria de T. brucei (FANG e BEATTIE, 2002). Esta enzima poderia ser responsável também pela oxidação de NADH, em substituição ao complexo I. Para T. cruzi, a atividade desta enzima não foi descrita e, certamente, este tema merece investigações futuras. No entanto, buscas de similaridade no genoma de $T$. cruzi, utilizando o programa BLASTN e como query a seqüência de uma NADH desidrogenase alternativa de $T$. brucei (GenBank: AY125472), mostraram um mRNA (GenBank: XM807104.1) que apresenta $\sim 70 \%$ de similaridade. 
Em resumo, os dados obtidos no presente estudo reforçam evidências anteriores de que o complexo I não é funcional ou é pouco funcional em $T$. cruzi. A favor desta hipótese menciona-se que cepas com deleção nos genes ND4 e ND7 são abundantes na natureza; apresentam crescimento normal em meio líquido (formas epimastigotas) e realizam todo o ciclo de infecção em células de mamífero em cultura (formas amastigotas e tripomastigotas) (dados de nosso laboratório). Além disso, estas cepas mantêm sua infectividade e patogenicidade, uma vez que foram isoladas de pacientes que apresentam as formas assintomáticas e sintomáticas da doença de Chagas.

Recentemente, foram apresentadas evidências de que nos tripanossomatídeos o complexo I mitocondrial não estaria envolvido em processos de transdução de energia (OPPERDOES e MICHELS, 2008). Os autores realizaram uma análise de bioinformática para predizer a composição deste complexo, o qual estaria constituído de, no mínimo, 19 subunidades. O complexo é maior que a enzima bacteriana correspondente, mas é menor que o complexo I típico dos eucariotos. No complexo I de $T$. brucei todas as subunidades envolvidas no transporte de elétrons estão presentes, no entanto, o complexo parece não estar envolvido na transdução de energia, uma vez que quatro subunidades integrais da membrana interna estão ausentes. Estas proteínas, normalmente codificadas pelo genoma mitocondrial, participam do processo de translocação de prótons para o espaço intermembranar.

Como hipótese para tentar explicar a conservação do complexo I em tripanossomatídeos, poderia ser sugerida sua função na manutenção da estrutura da membrana interna da mitocôndria. De fato, o complexo I é a estrutura de maior tamanho quando comparada aos demais complexos transportadores de elétrons.

\subsection{MEDIDA DO PERÓXIDO DE HIDROGÊNIO $\left(\mathrm{H}_{2} \mathrm{O}_{2}\right)$ LIBERADO PELA MITOCÔNDRIA}

É conhecido que a disfunção mitocondrial por defeitos no complexo I pode originar três tipos de problemas: (i) o balanço redóx da célula poderia ser comprometido, se a cadeia de transporte de elétrons for incapaz de oxidar NADH; (ii) 
haveria diminuição na síntese de ATP, se o bombeamento de prótons mediado pelo complexo I estiver danificado; (iii) a produção de radicais livres poderia ser acelerada (SEO et al., 1998).

Durante a transdução de energia na cadeia de transporte de elétrons, uma pequena porcentagem de elétrons volta para a matriz mitocondrial (principalmente pelos complexos I e III), determinando a formação do radical superóxido que é rapidamente dismutado pelas superóxido dismutases gerando $\mathrm{H}_{2} \mathrm{O}_{2}$, que se difunde facilmente através das membranas. A medida de peróxido de hidrogênio pode ser utilizada como um indicador estequiométrico de EROs mitocondrial (LOSCHEN et al., 1974; BOVERIS e CADENAS 1975).

A liberação de peróxido de hidrogênio pela mitocôndria tem sido caracterizada em vários sistemas de mamíferos (BOVERIS et al., 1976), e em T. cruzi (BOVERIS e STOPPANI, 1977). No presente trabalho, formulamos a hipótese de que a deleção em ND7 poderia favorecer ou inibir a formação de $\mathrm{H}_{2} \mathrm{O}_{2}$ no complexo I, a partir de substrato do complexo II. Neste sentido, avaliamos a quantidade de $\mathrm{H}_{2} \mathrm{O}_{2}$ liberada pela mitocôndria em cinco cepas, utilizando substratos para os complexos I e II. Os dados obtidos indicam não haver uma correlação entre o nível de liberação de $\mathrm{H}_{2} \mathrm{O}_{2}$ mitocondrial e a presença de deleção no gene ND7.

Por outro lado, observamos variações nos níveis de produção de $\mathrm{H}_{2} \mathrm{O}_{2}$ que parecem ser cepa-dependentes, constituindo uma característica adicional que confirma a diversidade bioquímica e funcional entre as populações de $T$. cruzi. É interessante notar que a produção de peróxido de hidrogênio, tanto com os substratos de complexo I, quanto de complexo II, é baixa em CL Brener ( 15 pmoles. $\left.\mathrm{min}^{-1} \cdot \mathrm{mg}^{-1}\right)$, e que os maiores valores são observados na cepa 115 ( 28 pmoles.min ${ }^{-1} \cdot \mathrm{mg}^{-1}$ ). Penketh e Klein. (1986) reportam uma liberação de $\mathrm{H}_{2} \mathrm{O}_{2}$ de $10 \mathrm{a}$ 40 pmoles. $\mathrm{min}^{-1} \cdot \mathrm{mg}^{-1}$ em T. brucei e Meshnik et al. (1978) reportam 200 pmoles.min ${ }^{1} . \mathrm{mg}^{-1}$ para o mesmo parasita. Boveris et al. (1978), utilizando a técnica de Scopoletin-HRP, não detectaram liberação de $\mathrm{H}_{2} \mathrm{O}_{2}$ em epimastigotas intactos, mas verificaram uma produção de $\mathrm{H}_{2} \mathrm{O}_{2}$ de 260 nmoles. $\min ^{-1} \cdot \mathrm{g}^{-1}$ em frações mitocondriais de epimastigotas submetidos a estímulo com $\beta$-lapachona. 


\subsection{MONITORAMENTO DOS NÍVEIS DE NAD MITOCONDRIAL}

Conforme comentado acima, observamos que a liberação de EROs mitocondrial, medida através da produção de $\mathrm{H}_{2} \mathrm{O}_{2}$, difere entre as cepas $115 \mathrm{e} \mathrm{CL}$ Brener. É conhecido que a cadeia de transporte de elétrons é um dos maiores geradores de EROs. Os elétrons derivados de equivalentes metabólicos reduzidos como NADH alimentam a cadeia de transporte de elétrons através do complexo I e passam, via complexo IV, ao oxigênio molecular para formar água. Termodinamicamente os transportadores de elétrons na sua forma reduzida podem "vazar" seus elétrons para o oxigênio gerando ânions superóxido.

Para verificar se existia correlação entre a liberação de $\mathrm{H}_{2} \mathrm{O}_{2}$ pela mitocôndria e a acumulação relativa de NADH, foi utilizada a propriedade do NADH de absorver luz num comprimento de onda de 352 nm e emitir luz em 464 nm. Para isso, nós utilizamos a antimicina $A$, um inibidor do complexo III que resulta num incremento na fluorescência e CCCP, um protonóforo desacoplador que causa a máxima oxidação e um decréscimo na fluorescência.

Os resultados mostraram uma diferença significativa na quantidade de NAD total acumulado na cepa 115 , que é $~ 40 \%$ maior em relação a CL Brener, quando são adicionados substratos para o complexo I. Esta observação poderia explicar a maior produção de peróxido de hidrogênio na cepa 115. Com substrato para o complexo II, não foi detectada uma diferença significativa na abundância de NAD total entre as cepas. Este resultado sugere um mecanismo de transferência reversa de elétrons produzidos na oxidação do succinato para o complexo I, reduzindo o $\mathrm{NAD}^{+}$para NADH (CHANCE e HOLLUNGER 1961a,b; HINKLE et al., 1967). Esta hipótese é apoiada pelos estudos de Liu et al. (2002) que demonstraram que mitocôndrias isoladas de cérebro de rato apresentavam uma geração de EROs fisiologicamente significativa a nível do complexo I, sustentada por succinato, mediante transferência reversa de elétrons. Além disso, foi observado que partículas mitocondriais obtidas de diferentes tecidos, ao serem suplementadas com substratos para o complexo II, são fontes ativas de geração de peróxido de hidrogênio (BOVERIS et al., 1976; TURRENS e BOVERIS, 1980). 


\subsection{SENSIBILIDADE DE ISOLADOS HUMANOS A PERÓXIDO DE HIDROGÊNIO}

Como foi mencionado, durante seu complexo ciclo de vida T. cruzi é exposto a diferentes EROs gerados pelo seu próprio metabolismo aeróbico, pela resposta imune do hospedeiro e por xenobióticos usados para o tratamento da doença (TURRENS, 2004).

EROs podem produzir, entre outras alterações, mutagênese e danos na maquinaria de reparo do DNA, rompimento de membranas e inativação de enzimas essenciais. O sucesso no estabelecimento da infecção num ambiente oxidante depende em grande parte da habilidade dos parasitas em sobreviver, utilizando mecanismos detoxificadores (BOVERIS et al., 1980).

Em nossos estudos, analisamos a sensibilidade a peróxido de hidrogênio em 15 cepas, isoladas de pacientes em diferentes fases da doença, assim como apresentando diferentes manifestações clínicas. Observamos que a concentração de peróxido de hidrogênio que inibe $50 \%$ da viabilidade dos parasitas $\left(\mathrm{Cl}_{50}\right)$ varia de 76 a $120 \mu \mathrm{M}$ entre as cepas. A ordem de grandeza da $\mathrm{Cl}_{50}$ determinada por nós é concordante com aquela reportada por outros grupos. De fato, Mielniczki-Pereira et al. (2007) reportaram $\mathrm{Cl}_{50}$ de $98,17 \pm 1,7 \mu \mathrm{M}$, para a cepa Y; Wilkinson et al. (2000), $96,7 \pm 2,3 \mu \mathrm{M}$, para a cepa Silvio; e Kelly et al. (1993), $155 \pm 25 \mu \mathrm{M}$ para a mesma cepa Silvio.

Arbitrariamente, dividimos as cepas em dois grupos: sensíveis e resistentes, considerando como ponto de corte $\mathrm{Cl}_{50}$ de $95 \mu \mathrm{M}$. A análise da diferença das médias de sensibilidade a peróxido de hidrogênio, mediante o teste t-Student, mostrou que os dois grupos são significativamente diferentes $(p=2.66 \mathrm{E}-6)$. Por outro lado, não verificamos nenhuma associação entre a sensibilidade das cepas a $\mathrm{H}_{2} \mathrm{O}_{2}$ e sua origem. 


\subsection{AVALIAÇÃO DOS NÍVEIS DE mRNA DE GENES PUTATIVAMENTE ENVOLVIDOS NA DETOXIFICAÇÃO DE EROS}

Avaliamos a abundância de transcritos de alguns genes potencialmente envolvidos nos mecanismos de defesa contra EROs nas cepas cuja sensibilidade a peróxido de hidrogênio havia sido determinada. Os genes escolhidos foram aqueles que codificam a superóxido dismutase (SOD), tripanotiona sintetase e triparedoxina peroxidase. Estes genes apresentaram expressão diferencial entre as cepas $115 \mathrm{e}$ VL10, que apresentam diferentes sensibilidades a $\mathrm{H}_{2} \mathrm{O}_{2}$, em experimentos com microarranjos de DNA executados por Margoth Moreno em nosso laboratório.

É conhecido que o $\mathrm{O}_{2}^{--}$pode causar dano biológico, direta ou indiretamente, pela formação de produtos secundários através da interação com EROs e nitrogênio ou metais de transição. Os tripanossomatídeos desenvolveram diferentes mecanismos para combater o estresse oxidativo, alguns dos quais são diferentes daqueles observados em outros eucariotos (FAIRLAMB et al., 1992; FLOHE et al., 1999; KRAUTH-SIEGEL et al., 2003). Para o metabolismo de $\mathrm{O}_{2}{ }^{-{ }^{-}}$, os tripanossomatídeos expressam as enzimas antioxidantes superóxido dismutases (SOD), metalo-proteínas que funcionam removendo o excesso de $\mathrm{O}_{2}{ }^{--}$para formar $\mathrm{H}_{2} \mathrm{O}_{2}$ e $\mathrm{O}_{2}$. Nestes organismos apenas Fe-SOD são observadas (LE TRANT et al., 1983; KABIRI et al., 2001), representadas em quatro isoformas: FeSOD-A e FeSODC, de localização mitocondrial, FeSOD-B1, localizada no glicossomo e FeSOD-B2, no glicossomo e citossol (WILKINSON et al., 2006). Para FeSOD-A dois transcritos diferentes foram observados em T. cruzi (FeSOD-A ${ }^{1}$ e Fe-SOD-A ${ }^{2}$ ) (NOGUEIRA et al., 2006). Em cepas com resistência induzida a xenobióticos foi relatado um aumento nos transcritos de FeSOD-A, com conseqüente aumento nos níveis de proteína e atividade enzimática (NOGUEIRA et al., 2006).

Inicialmente investigamos por RT-PCR em tempo real a abundância de transcritos das duas isoformas de FeSOD-A na cepa $115\left(\mathrm{Cl}_{50} 107,85 \pm 1,1 \mu \mathrm{M}\right.$ para $\left.\mathrm{H}_{2} \mathrm{O}_{2}\right)$ e VL10 $\left(\mathrm{Cl}_{50} 81,86 \pm 6,9 \mu \mathrm{M}\right.$ para $\left.\mathrm{H}_{2} \mathrm{O}_{2}\right)$. Observamos uma abundância 3,8 vezes maior do transcrito de FeSOD-A ${ }^{1}$, mas não de Fe-SOD-A ${ }^{2}$, em 115 em relação a VL10. Isto estaria concordante com a maior resistência da cepa 115 a peróxido de hidrogênio. Por outro lado, para as cepas 115 e CL Brener, que apresentam o mesmo grau de sensibilidade a peróxido de hidrogênio, observamos um acúmulo de 
transcritos de FeSOD-A ${ }^{1}$ e de FeSOD-A ${ }^{2}$, 3,9 e 2,9 vezes maior em 115 do que CL Brener. Estas observações sugerem que não há uma correlação entre a abundância dos transcritos de ambas FeSOD-A e o fenótipo de resistência a $\mathrm{H}_{2} \mathrm{O}_{2}$. Esta conclusão foi corroborada pela análise da abundância relativa dos transcritos das duas isoformas de FeSOD-A em 10 cepas de T. cruzi que apresentam diferentes graus de sensibilidade ao peróxido de hidrogênio.

Foi estabelecido que em tripanossomatídeos as vias metabólicas mediadas por enzimas para eliminar $\mathrm{H}_{2} \mathrm{O}_{2}$ são dependentes de tripanotiona e de sua enzima auxiliar, a tripanotiona redutase (FAIRLAMB et al., 1992; SHAMES et al.,1986). Este sistema, análogo ao ciclo redóx da glutationa encontrado em eucariotos superiores, apresenta uma cascata de oxidoredutases que termina na redução de $\mathrm{H}_{2} \mathrm{O}_{2}$ gerando água e oxigênio (NOGOCEKE et al.,1997; WILKINSON et al., 2002). Esta via de detoxificação foi detectada em vários compartimentos celulares geradores de EROs, incluindo a mitocôndria, glicossomo, retículo endoplasmático e citossol (WILKINSON et al., 2006). A tripanotiona sintetase catalisa a adição de uma segunda molécula de glutationa à glutationil-espermidina, gerando tripanotiona (FAIRLAMB et al., 1992; OZA et al., 2005). Em T. cruzi, a redução de $\mathrm{H}_{2} \mathrm{O}_{2}$ é realizada pela atividade de duas triparedoxina peroxidases (KRAUTH-SIEGEL et al., 2003), uma citossólica (TcCPX) e outra mitocondrial (TcMPX) (WILKINSON et al., 2000a).

Estudamos a abundância de transcritos da triparedoxina peroxidase citossólica (TcCPX) e tripanotiona sintetase em 10 cepas com diferentes graus de resistência e/ou sensibilidade ao peróxido de hidrogênio. A diferença nas médias de abundância de transcritos da TcCPX não mostrou correlação com os grupos de cepas consideradas sensíveis ou resistentes a $\mathrm{H}_{2} \mathrm{O}_{2}$. Já para tripanotiona sintetase, a análise estatística dos dados sugere uma abundância de transcritos maior nas cepas sensíveis em relação às resistentes a $\mathrm{H}_{2} \mathrm{O}_{2}$. Do ponto de vista biológico/fisiológico é difícil explicar este resultado. Por outro lado, tendo em vista que nos Kinetoplastida o controle de expressão gênica é exercido no nível póstranscricional, a abundância de determinado mRNA não significa necessariamente maior abundância da proteína correspondente. Desta forma, será necessário determinar os níveis e atividade das enzimas envolvidas em mecanismos de detoxificação de EROs para que conclusões mais definitivas possam ser estabelecidas. 


\section{CONCLUSÕES}

\subsection{ESTRUTURA DOS GENES DO MAXICÍRCULO ND7, ND4 E COIII}

- O gene ND7 apresenta um dimorfismo nos isolados de T. cruzi.

- Em alguns isolados, o gene ND7 apresenta uma deleção conservada de 455 pb que se estende da posição 222 a 677 nt com relação ao gene ND7 das cepas CL Brener e Esmeraldo.

- Os isolados que apresentam deleção em ND7 pertencem ao grupo T. cruzi II, sub-grupo DTU Ilb.

- A deleção em ND7 é um evento antigo, que deve ter ocorrido num ancestral DTU Ilb comum aos isolados que apresentam o gene ND7 com deleção.

- O gene ND4 apresenta um dimorfismo nos isolados de T. cruzi.

- Os isolados que apresentam deleções em ND7 e ND4 são viáveis e conservam sua capacidade infectante.

- O gene COIII, contíguo a ND7, apresenta uma estrutura conservada nos isolados analisados.

\subsection{GENOTIPAGEM DE ISOLADOS HUMANOS}

- Não há correlação entre o tamanho do produto de amplificação de ND7 ou ND4 e as apresentações clínicas da doença de Chagas (forma indeterminada ou cardíaca). 
- Em trabalho em colaboração, concluímos que todos os isolados dos pacientes analisados (exceto um), portadores das formas indeterminada ou cardíaca da doença de Chagas, pertencem ao sub-grupo DTU Illb.

\subsection{PARÂMETROS DO FUNCIONAMENTO DA MITOCÔNDRIA}

- As deleções nos genes ND7 e ND4 não afetam a velocidade de consumo de oxigênio com substratos do complexo I ou II de respiração.

- O complexo I mitocondrial não é funcional ou é pouco funcional em formas epimastigotas de T. cruzi.

- Evidências indiretas sugerem que parte do NADH formado na mitocôndria é oxidado via fumarato redutase.

- Os níveis de produção de $\mathrm{H}_{2} \mathrm{O}_{2}$ pela mitocôndria não apresentam correlação com a presença das deleções nos genes ND7 ou ND4. As diferenças observadas parecem ser cepa-específicas .

- A maior quantidade de NAD total acumulado na cepa 115 pode estar relacionada com a maior quantidade de $\mathrm{H}_{2} \mathrm{O}_{2}$ liberada pela mitocôndria nesta cepa.

\subsection{SENSIBILIDADE DE ISOLADOS A PERÓXIDO DE HIDROGÊNIO}

- A sensibilidade a $\mathrm{H}_{2} \mathrm{O}_{2}$ exógeno é uma propriedade particular de cada isolado e não apresenta associação com a origem do mesmo.

- A abundância de transcritos dos genes das duas isoformas de FeSOD-A e da triparedoxina peroxidase não apresenta correlação com o fenótipo de sensibilidade a $\mathrm{H}_{2} \mathrm{O}_{2}$. 
- A abundância de transcritos do gene da tripanotiona sintetase é maior nas cepas sensíveis ao $\mathrm{H}_{2} \mathrm{O}_{2}$. 


\section{REFERÊNCIAS *}

ABDRAKHMANOVA, A.; ZICKERMANN, V.; BOSTINA, M.; RADERMACHER, M.; SCHAGGER, H.; KERSCHER, S.; BRANDT, U. Subunit composition of mitochondrial complex I from the yeast Yarrowia lipolytica, Biochim. Biophys. Acta, v.1658, p.148-156, 2004.

ABEL, L.; RIZZO, L.; IANNI, B.; ALBUQUERQUE, F.; BACAL, F.; CARRARA, D.; BOCCHI, E.; TEIXEIRA, H.; MADY, C.; KALIL, J.; CUNHA-NETO, E. CHRONIC CHAGAS' DISEASE cardiomyopathy patients display an increased IFN-gamma response to Trypanosoma cruzi infection. J. Autoimmun., v.17, p.99-107, 2001.

ALFONZO, J.; THIEMANN, O.; SIMPSON, L. The mechanism of $U$ insertion/deletion RNA editing in kinetoplastid mitochondria. Nucleic. Acids. Res., v.25, p.3751-3759, 1997.

ALPHEY, M.; BOND, C.; TETAUD, E.; FAIRLAMB, A.; HUNTER, W. The structure of reduced tryparedoxin peroxidase reveals a decamer and insight into the reactivity of 2Cys-peroxiredoxins. J. Mol. Biol., v.300, p.903-916, 2000.

ALPHEY, M.; LEONARD, G.; GOURLEY, D.; TETAUD, E.; FAIRLAMB, A.; HUNTER, W. The high resolution crystal structure of recombinant Crithidia fasciculata tryparedoxin-1. J. Biol .Chem., v.274, p.25613-25622, 1999.

ANDRADE, L.; MACHADO, C.; CHIARI, E.; PENA, S.; MACEDO, A. Differential tissue distribution of diverse clones of Trypanosoma cruzi in infected mice. Mol. Biochem. Parasitol., v.100, p.163-172,1999.

AÑEZ, N.; CRISANTE, G.; DA SILVA, F.; ROJAS, A.; CARRASCO, H.; UMEZAWA, E.; STOLF, A.; RAMÍREZ, J.; TEIXEIRA, M. Predominance of lineage I among rypanosoma cruzi isolates from Venezuelan patients with different clinical profiles of acute Chagas' disease. Trop. Med. Int .Health, v.9, p.1319-1326, 2004.

ANÔNIMO. Recommendations from an International Symposium to Commemorate the $90^{\text {th }}$ Anniversary of discovery of Chagas disease. Mem. Inst. Oswaldo Cruz, v. 94, p.429-432, 1999.

*De acordo com:

ASSOCIAÇÃO BRASILEIRA DE NORMAS TÉCNICAS. NBR 6023: Informação e documentação: referências: elaboração. Rio de Janeiro, 2002. 
ARIKAWA, Y.; ENOMOTO, K.; MURATSUBAKI, H.; OKAZAKI, M. Soluble fumarate reductase isoenzymes from Saccharomyces cerevisiae are required for anaerobic growth. FEMS. Microbiol. Lett., v.165, p.111-116, 1998.

ATWOOD, J.; WEATHERLY, D.; MINNING T.; BUNDY, B.; CAVOLA, C.; OPPERDOES, F.; ORLANDO, R.; TARLETON, R. The Trypanosoma cruzi proteome. SCIENCE, v.309, P.473-476, 2005.

AUGUSTO-PINTO, L.; TEIXEIRA, S.; PENA, S.; MACHADO, C. Single nucleotide polymorphisms of the Trypanosoma cruzi MSH2 gene support the existence of the three phylogenetic lineages presenting differences in mismatch-repair efficiency. Genetics, v.164, p.117-126, 2003.

BAPTISTA, C.; VENCIO, R.; ABDALA, S.; CARRANZA, J.; WESTERBERGER, S.; SILVA, M.; DE B PEREIRA, C.; GALVÃO, L.; GONTIJO, E.; CHIARI, E.; STURM, N.; ZINGALES, B. Differential transcription profiles in Trypanosoma cruzi associated with clinical forms of Chagas disease: Maxicircle NADH dehydrogenase subunit 7 gene truncation in asyntomatic patient isolates. Mol. Biochem. Parasitol., v.150, p.236248, 2006.

BAPTISTA, C.; VENCIO, R.; ABDALA, S.; VALADARES, M.; MARTINS, C.; DE B PEREIRA, C.; ZINGALES, B. DNA microarrays for comparative genomics and analysis of gene expression in Trypanosoma cruzi. Mol. Biochem. Parasitol., v.138, p.183-194, 2004.

BARRET, M.; BURCHMORE, R.; STICH, A.; LAZZARI, J.; FRASCH, A.; CAZZULO, J. The trypanosomiases. LANCET, v.362, p. 1469-80, 2003.

BEATTIE, D.; HOWTON, M. The presence of rotenone-sensitive NADH dehydrogenase in the long slender bloodstream and the procyclic forms of Trypanosoma brucei brucei. Eur .J. Biochem., v.241, p. 888-894, 1996.

BERRIMAN, M. et al. The genome of the African trypanosome Trypanosoma brucei. Science, v.309, p.416-422, 2005.

BESTEIRO, S.; BARRETT, M.; RIVIERE, L.; BRINGAUD, F. Energy generation in insect stages of Trypanosoma brucei: metabolism in flux. Trends. Parasitol., v. 21, p.185-189, 2005.

BESTEIRO, S.; BIRAN, M.; BITEAU, N.; COUSTOU, V.; BALTZ, T.; CANIONI, P.; BRINGAUD, F. Succinate Secreted by Trypanosoma brucei Is Produced by a Novel 
and Unique Glycosomal Enzyme, NADH-dependent Fumarate Reductase. J. Biol. Chem., v. 277, p. 38001-38012, 2002.

BIRNBOIM, H.; DOLY, J. A rapid alkaline extraction procedure for screening recombinant plasmid DNA. Nucl. Acid. Res., v.7, p.1513-1523, 1979.

BOCHUD-ALLEMANN, N.; SCHNEIDER, A. Mitochondrial substrate level phosphorylation is essential for growth of procyclic Trypanosoma brucei. J. Biol. Chem., v.277, p.32849-32854, 2002.

BOVERIS, A.; CADENAS, E. Mitochondrial production of superoxide anions and its relationship to antimycin insensitive respiration. FEBS Lett., v.54, p.311-314, 1975.

BOVERIS, A.; CADENAS, E.; STOPPANI, O. Role of ubiquinone in the mitochondrial generation of hydrogen peroxide. Biochem. J., v.156, p.435-444, 1976.

BOVERIS, A.; DOCAMPO, R.; TURRENS, J.; STOPPANI, A. Effect of betalapachone on superoxide anion and hydrogen peroxide production in Trypanosoma cruzi. Biochem. J., v175, p.431-439, 1978.

BOVERIS, A.; HERTIG, C.; TURRENS, J. Fumarate reductase and other mitochondrial activities in Trypanosoma cruzi. Mol. Biochem. Parasitol., v.19, p.163169, 1986.

BOVERIS, A.; SIES, H.; MARTINO, E.; DOCAMPO, R.; TURRENS, J.; STOPPANI, A.; Deficient metabolic utilization of hydrogen peroxide in Trypanosoma cruzi. Biochem. J., v.188, p. 643-648, 1980.

BOVERIS, A.; STOPPANI, A. Hydrogen peroxide generation in Trypanosoma cruzi. Experientia, v.33, p.1306-1308, 1977.

BRADFORD, M. A rapid and sensitive method for the quantitation of microgram quantities of protein utilizing the principle of protein-dye binding. Anal. Biochem., v.72, p.248-254, 1976.

BRANDT, U. Energy Converting NADH:Quinone Oxidoreductase (Complex I) Annu. Rev. Biochem., v.75, p.69-92, 2006. 
BRINGAUD, F.; RIVIERE, L.; COUSTOU, V. Energy metabolism of trypanosomatids: Adaptation to available carbon sources. Mol. Biochem. Parasitol., v.149.; p. 1-9, 2006.

BRISSE, S.; DUJARDIN, JP.; TIBAYRENC, M. Identification of six Trypanosoma cruzi lineages by sequence-characterised amplified region merkers. Mol. Biochem. Parasitol., v.111, p. 95-105, 2000.

BRISSE, S.; HENRIKSSON, J.; BARNABE, C.; DOUZERY, E.; BERKVENS, D.; SERRANO, M.; DE-CARVALHO, M.; BUCK, G.; DUJARDIN, JP.; TIBAYRENC, M. Evidence for genetic exchange and hybridization in Trypanosoma cruzi based on nucleotide sequences and molecular karyotype. Infect. Genet. Evol., v.2, p.173-183, 2003.

BURSELL, E. The role of proline in energy metabolism. In: DOWNER RGH. Energy metabolism in insects. New York, Plenum Press, 1981. p.135-54.

BURSELL, J.; KIRK, J.; HALL, S.; GERO, A.; KIRK, K. Volume-regulatory amino acid release from the protozoan parasite Crithidia luciliae. J. Membr. Biol., v.154, p.131$141,1996$.

CALDAS, R.; ARAÚJO, E.; FELIX, R.; ROITMAN, I.; Incorporation of ammonium in amino acids by Trypanosoma cruzi. J. Parasitol., v.66, p.213-216, 1980.

CAMARGO, E. Growth and differentiation of Trypanosoma cruzi. I. Origin of metaciclic trypanosomes in liquid media. Rev. Inst. Med. Trop., v.6, p.93 - 100, 1964.

CAMPBELL, D.; WESTENBERGER, S.; STURM NR. The determinants of Chagas disease: connecting parasite and host genetics. Curr. Mol. Med., v.4, p.549-562, 2004. Review.

CANNATA, J.; CAZZULO, J. The aerobic fermentation of glucose by Trypanosoma cruzi. Comp. Biochem. Physiol. B., v.79, p.297-308, 1984.

CARDOL, P.; LAPAILLE, M.; MINET, P.; FRANCK, F.; MATAGNE, R.; REMACLE, C. ND3 and ND4L Subunits of Mitochondrial Complex I, Both Nucleus Encoded in Chlamydomonas reinhardtii, Are Required for Activity and Assembly of the Enzyme. Eukaryotic. Cell., v.5, p. 1460-1467, 2006. 
CARDOL, P.; VANROBACYS, F.; DEVREESE, B.; VAN BECUMEN, J.; MATAGNE, R.; REMACLE, C. Higher plant-like subunit composition of the mitochondrial complex I from Chlamydomonas reinhardtii; 31 conserved components among eukariotes. Biochim. Biophys. Acta, v.1658, p.212-224, 2004.

CARLIER, Y.; TORRICO, F. Congenital infection with Trypanosoma cruzi: from mechanisms of transmission to strategies for diagnosis and control. Rev. Soc. Brasil Méd. Trop., v.36, p.767 - 771, 2006.

CARROL, J.; FEARNLEY, I.; SHANNON, R.; HIRST, J.; WALKER, F. Analysis of the subunit composition of complex I from bovine heart mitochondria. Mol. Cell. Proteomics, v.2, p.117-126, 2003.

CAZZULO, J. Aerobic fermentation of glucose by trypanosomatids. FASEB, v.6, p.3153-3161, 1992.

CAZZULO, J. Intermediate metabolism in Trypanosoma cruzi. J. Bioenerg. Biomembr., v.26, p.157-165, 1994.

CAZZULO, J.; FRANKE, B.; ENGEL, J.; CANNATA, J. End products and enzyme levels of aerobic glucose fermentation in trypanosomatids. Mol. Biochem. Parasitol., v.16, p.329-343, 1985.

CAZZULO, J.; JUAN, S.; SEGURA, E., Glutamate dehydrogenase and aspartate aminotransferase in Trypanosoma cruzi. Comp. Biochem. Physiol. B., v.56, p.301303, 1977.

CHAMOND, N.; GREGOIRE, C.; COATNOAN, N.; ROUGEOT, C.; FREITASJUNIOR, L.; DA SILVEIRA, J.; DEGRAVE, W.; MINOPRIO, P. Biochemical characterization of proline racemases from the human protozoan parasite Trypanosoma cruzi and definition of putative protein signatures. J. Biol. Chem., v.278, p.15484-15494, 2003.

CHANCE, B.; HOLLUNGER, G. The interaction of energy and electron transfer reactions in mitochondria. I. General properties and nature of the products of succinate-linked reduction of pyridine nucleotide. J. Biol. Chem., v.236, p.15341543, 1961a.

CHANCE, B.; HOLLUNGER, G. The interaction of energy and electron transfer reactions in mitochondria. IV. The pathway of electron transfer. J. Biol. Chem., v.236, p.1562-1568, 1961b. 
CHANCE, B.; LAGALLIAS, V. Differential microfluorimeter for the localization of reduced pyridine nucleotide in living cells. Rev. Sci. Instrum., v.30, p.732-735, 1959.

CHAUDHURI, M.; OTT, R.; HILL, G. Trypanosome alternative oxidase: from molecule to function. TRENDS Parasitol., v.22, p. 484-491, 2006. Review.

CHEN, Q.; VAZQUEZ, E.; MOGHADDAS, S.; HOPPEL, C.; LESNEFSKY, E. Production of Reactive Oxygen Species by Mitochondria. Central role of complex III. J. Biol. Chem., v.278, p. 36027-36031, 2003.

CHIARI, E.; DIAS, J.; LANA, M.; CHIARI, C. Hemocultures for the parasitological diagnosis of human chronic Chagas' disease. Rev. Soc. Bras. Med. Trop., v.22, p.19-23, 1989.

CONCEPCION, J.; ACOSTA, H.; QUIÑONES, W.; DUBOURDIEU, M. A $\alpha$ glycerophosphate Dehydrogenase is Present in Trypanosoma cruzi Glycosomes. Mem. Inst. Oswaldo Cruz, Rio de Janeiro, v.96, p. 697-701, 2001.

CONTRERAS, V.; SALLES, M.; THOMAS, N.; MOREL, C.; GOLDENBERG, S. In vitro differentiation of Trypanosoma cruzi under chemically defined conditions. Mol. Biochem. Parasitol., v.16, p.315-327, 1985.

COURA, J.; JUNQUEIRA, A.; FERNANDES, O.; VALENTE, S.; MILES, M. Emerging Chagas disease in Amazonian Brazil. TRENDS Parasitol., v.18, p.171-176, 2002.

COUSTOU, V.; BESTEIRO, S.; BIRAN, M.; DIOLEZ, P.; BOUCHAUD, V.; VOISIN, P.; MICHELS, P.; CANIONI, P.; BALTZ, T.; BRINGAUD, F. ATP generation in the Trypanosoma brucei procyclic form: cytosolic substrate level phosphorylation is essential, but not oxidative phosphorylation. J. Biol. Chem., v.278, p.49625-49635, 2003.

COUSTOU, V.; BESTEIRO, S.; RIVIERE, L.; BIRAN, M.; BITEAU, N.; FRANCONI, J.; BOSHART, M.; BALTZ, T.; BRINGAUD, F. A Mitochondrial NADH-dependent fumarate reductase involved in the production of succinate excreted by procyclic Trypanosoma brucei. J. Biol. Chem., v.280, p. 16559-16570, 2005.

COUSTOU, V.; BIRAN, M.; BESTEIRO, S.; RIVIERE, L.; BALTZ, T.; FRANCONI, J.; BRINGAUD, F. A Fumarate is an essential intermediary metabolite produced by the procyclic Trypanosoma brucei. J. Biol. Chem., v.281, p. 26832-26846, 2006. 
COUSTOU, V.; BIRAN, M.; BRETON, M.; GUEGAN, F.; RIVIÈRE, L.; PLAZOLLES, N.; NOLAN, D.; BARRETT, M.; FRANCONI, J.; BRINGAUD, F. Glucose-Induced Remodelling of Intermediary and Energy Metabolism in Procyclic Trypanosoma brucei. J. Biol. Chem., v.283, p. 16342-16354, 2008.

CRUZ, R.; MACEDO, A.; BARNABÉ, C.; FREITAS, J.; CHIARI, E.; VELOSO, V.; CARNEIRO, C.; BAHIA, M.; TAFURI, W.; LANA, M. Further genetic characterization of the two Trypanosoma cruzi Berenice strains (Be-62 and Be-78) isolated from the first human case of Chagas disease (Chagas, 1909). Acta Trop., v.97, p.239-246, 2006.

D`ORSO, I.; FRASCH, A. Functionally differente AU and G-rich cis-elements confer developmentally regulated mRNA stability in Trypanosoma cruzi by interaction with specific RNA-binding proteins. J. Biol. Chem., v.276, p.15783-15793, 2001.

DAS, A. Studies on mitochondrial ATPase of Leishmania donovani usimg digitoninapermeabilized promastigotes. Mol. Biochem. Parasitol., v.60, p.293-302, 1993.

DENICOLA-SEOANE, A.; RUBBO, H.; HADEN, L.; TURRENS, J. Extramitochondrial localization of NADH-fumarate reductase in trypanosomatids. Comp. Biochem. Physiol., v.133, p.23-27, 2002.

DENICOLA-SEOANE, A.; RUBBO, H.; PRODANOV, E.; TURRENS, J. Succinatedependent metabolism in Trypanosoma cruzi epimastigotas. Mol. Biochem. Parasitol., v.54, p. 43-50, 1992.

DOCAMPO, R.; e VERCESI, A. Ca ${ }^{2+}$ Transport by Coupled Trypanosoma cruzi Mitochondria in Situ. J. Biol. Chem., v.264, p. 108-111, 1989.

DUAN, S.; HÁJEK, P.; LIN, C.; SHIN, S.; ATTARDI, G.; CHOMYN, A. Mitochondrial outer membrane permeability change and hypersensitivity to digitonina early in staurosporine-induced apoptosos. J. Biol. Chem., v.278, p.1346-1353, 2003.

DUFERNEZ, F.; YERNAUX, C.; GERBOD, D.; NOEL, C.; CHAUVENET, M.; WINTJENS, R.; EDGCOMB, V.; CAPRON, M.; OPPERDOES, F.; VISCOGLIOSI, E. The presence of four iron-containing superoxide dismutase isozymes in Trypanosomatidae: characterization, subcellular localization, and phylogenetic origin in Trypanosoma brucei. Free Rad. Biol. Med., v.40, p. 210-225, 2006.

DUFFIEUX, F.; VAN ROY, J.; MICHELS, P.; OPPERDOES, F. Molecular characterization of the first two enzymes of the pentosephosphate pathway of 
Trypanosoma brucei. Glucose-6-phosphate dehydrogenase and 6phosphogluconolactonase. J. Biol. Chem., v.275, p.27559-27565, 2000.

ELLINGTON, W. Evolution and physiological roles of phosphagen systems. Annu. Rev. Physiol., v.63, p.289-325, 2001.

EL-SAYED, N. et al. The genome sequence of Trypanosoma cruzi, etiologic agent of Chagas disease. Science, v.309, p.409-415, 2005.

ENGEL, J.; DOYLE, P.; DVORAK, J. Isolate-dependent differences in the oxidative metabolism of Trypanosoma cruzi epimastigotas. Mol. Biochem. Parasitol., v.39, p. 69-76, 1990.

ESTABROOK, R. Mitochondrial respiratory control and the polarographic measurement of ADP:O ratios. Methods Enzymol., v.10, p.41-48, 1967.

FAIRLAMB, A.; CERAMI, A. Metabolism and functions of trypanothione in the kinetoplastida. Annu. Rev. Microbiol., v.46, p.695-729, 1992.

FANG, J.; BEATTI,E D. Novel FMN-containing rotenone-insensitive NADH dehydrogenase from Trypanosoma brucei mitochondria: isolation and characterization. Biochemistry, v.41, p.3065-3072, 2002.

FANG, J.; BEATTIE, D. Rotenone-insensitive NADH dehydrogenase is a potential source of superoxide in procyclic Trypanosoma brucei mitochondria. Mol. Biochem. Parasitol., v.127, p.135-142, 2003.

FANG, J.; WANG, Y.; BEATTIE, D. Isolation and characterization of complex I, rotenone-sensitive NADH:ubiquinone oxidoreductase, from the procyclic forms of Trypanosoma brucei. Eur. J. Biochem., v.268, p.3075-3082, 2001.

FELIX, C.; CALDAS, R.; CERON, C.; ROITMAN L. Cyanide sensitive and insensitive respiration of Trypanosoma cruzi. Ann. Trop. Med. Parasitol., v.72, p.89-91, 1978.

FERELLA, M.; MONTALVETTI, A.; ROHLOFF, P.; MIRANDA, K.; FANG, J.; REINA, S.; KAWAMUKAI, M.; BUA, J.; NILSSON, D.; PRAVIA, C.; KATZIN, A.; CASSERA, M.; ÅSLUND, L.; ANDERSSON, B.; DOCAMPO, R.; BONTEMPI, E. A Solanesyldiphosphate Synthase Localizes in Glycosomes of Trypanosoma cruzi. J. Biol. Chem., v.281, p.39339-39348, 2006. 
FERNANDES, O.; STURM, N.; DERRÉ, R.; CAMPBELL, D. The mini-exon gene: a genetic marker for zymodeme III of Trypanosoma cruzi. Mol. Biochem. Parasitol., v.95, p.129-133, 1998.

FINZI, J.; CHIAVEGATTO, C.; CORAT, K.; LOPEZ, J.; CABRERA, O.; MIELNICZKIPEREIRA, A.; COLLI, W.; ALVES, M.; GADELHA, F. Trypanosoma cruzi response to the oxidative stress generated by hydrogen peroxide. Mol. Biochem. Parasitol., v.133, p.37-43, 2004.

FLOHE, L.; HECHT, J.; STEINERT, P. Glutathione and trypanothione in parasitic hydroperoxide metabolism. Free. Radic. Biol. Med., v.27, p.966-984, 1999.

FREITAS, J.; AUGUSTO-PINTO, L.; PIMENTA, J.; BASTOS-RODRIGUES, L.; GONÇALVES, V.; TEIXEIRA, S.; CHIARI, E.; JUNQUEIRA, A.; FERNANDES, O.; MACEDO, A.; MACHADO, C.; PENA, S. Ancestral Genomes, Sex, and the Population Structure of Trypanosoma cruzi. PLoS Pathog., v.2, p.226-235, 2006.

FREITAS, J.; LAGES-SILVA, E.; CREMA, E.; PENA, S.; MACEDO, A. Real Time PCR strategy for the identification of major lineages of Trypanosoma cruzi directly in chronically infected human tissues. Int. J. Parasitol., v.35, p.411-417, 2005.

FRYDMAN, B.; DE LOS SANTOS, C.; CANNATA, J.; CAZZULO, J. Carbon-13 nuclear magnetic resonance analysis of [1-13C]glucose metabolism in Trypanosoma cruzi. Evidence of the presence of two alanine pools and of two $\mathrm{CO}_{2}$ fixation reactions. Eur. J. Biochem., v.11, p.363-368, 1990.

GONZALES-HALPHEN, D.; MASLOV, D. NADH-ubiquinone oxidoreductase activity in the kinetoplasts of the plant trypanosomatid Phytomonas serpens. Parasitol. Res., v.92, p.341-346, 2004.

GOYAL, N.; ROY, U.; RASTOGI, A. Relative resistence of promastigotes of a virulent and an avirulent strain of Leishmania donovani to hydrogen peroxide. Free Radic. Biol. Med., v.21, p.683 - 689, 1996.

HEISE, N.; OPPERDOES, F. Purification, localisation and characterisation of glucose-6-phosphate dehydrogenase of Trypanosoma brucei. Mol. Biochem. Parasitol., v.99, p.21-32, 1999.

HERNANDEZ, F.; TURRENS, J. Rotenone at high concentrations inhibits NADHfumarate reductase and the mitochondrial respiratory chain of Trypanosoma brucei and T. cruzi. Mol. Biochem. Parasitol., v.93, p.135-137, 1998. 
HILL, G.; CROSS, G. Cyanide-resistant respiration and a branched cytochrome system in Kinetoplastidae. Biochim. Biophys. Acta, v.305, p.590-596, 1973.

HINKLE, P.; BUTOW, R.; RACKER, E.; CHANCE, B. Partial resolution of the enzymes catalyzing oxidative phosphorylation. XV. Reverse electron transfer in the flavin-cytochrome $b$ region of the respiratory chain of beef heart submitochondrial particles. J. Biol. Chem., v.242, p.5169, 1967.

HIRST, J.; CARROLL, J.; FEARNLEY, I. SHANNON, R.; WALKER, J. The nuclear encoded subunits of complex I from bovine heart mitochondria. Biochim. Biophys. Acta, v.1604, p.135-150, 2003.

HOMSY, J.; GRANGER, B.; KRASSNER, S. Some factors inducing formation of metacyclic stages of Trypanosoma cruzi. J. Protozool., v.36, p.150-153,1989.

HORVÁTH, A.; HORÁKOV,Á E.; DUNAJCIKOVA, P.; VERNER, Z.; PRAVDOVA, E.; LAPETOVA, I.; CUNINKOVA, L.; LUKES, J. Downregulation of the nuclear-encoded subunits of the complexes III and IV disrupts their respective complexes but not complex I in procyclic Trypanosoma brucei. Mol. Microbiol., v.58, p.116-130, 2005.

ISMAIL, S.; PARAMCHUCK, W.; SKEIKI, Y.; REED, S.; BHATIA, A.; GEDAMI, L. Molecular cloning and characterization of two iron superoxide dismutase cDNAs from Trypanosoma cruzi. Mol. Biochem. Parasitol., v.86, p.187-197, 1997.

IVENS, A. et al. The genome of the kinetoplastid parasite, Leishmania major. Science, v.309, p.436-42, 2005.

KABIRI, M.; STEVERDING, D. Identification of a developmentally regulated iron superoxide dismutase of Trypanosoma brucei. Biochem. J., v.360, p.173-177, 2001.

KASHANI-POOR, N.; ZWICKER, K.; KERSCHER, S.; BRANDT, U. A Central Functional Role for the $49-\mathrm{kDa}$ Subunit within the Catalytic Core of Mitochondrial Complex I. J. Biol. Chem., v.276, p.24082-24087, 2001.

KELLY, J.M.; TAYLOR, M.; SMITH, K.; HUNTER, K.; FAIRLAMB, A. Phenotype of recombinant Leishmania donovani and Trypanosoma cruzi which overexpress trypanothione reductase. Eur. J. Biochem., v.218, p.29-37, 1993. 
KIRCHHOFF, L.; WEIS, L.; WITTNER, M.; TANOWITZ HB. Parasitic disease of the heart. Front. Biosci., v.9, p.706-723, 2004.

KOSLOWSKY, D.; BHAT, G.; PERROLAZ, A.; FEAGIN, J.; STUART, K. The MURF3 gene of $T$. brucei contains multiple domains of extensive editing and is homologous to a subunit of NADH dehydrogenase. Cell, v.62, p.901-911, 1990.

KRAUTH-SIEGEL, R.; MEIERING, S.; SCHMIDT, $H$. The parasitespecific trypanothione metabolism of trypanosoma and leishmania. Biol. Chem., v.384, p.539- 549, 2003.

KRUGER, B.; SCHROPPEL, B.; ASHKAN, R.; MARDER, B.; ZÜLKE, C.; MURPHY, B.; KRÄMER, B.; FISCHEREDER, M. A monocyte chemoattractant protein-1 (MCP1) polymorphism and outcome after renal transplantation. J. Am. Soc. Nephrol., v.13, p.2585-2589, 2002.

LAGES-SILVA, E.; RAMIREZ, L.; PEDROSA, A.; CREMA, E.; DA CUNHA GALVÃO, L.; PENA, S.; MACEDO, A.; CHIARI, E. Variability of kinetoplast DNA gene signatures of Trypanosoma cruzi II strais from patientes with different clinical forms of Chagas disease in Brazil. J. Clin. Microbiol., v.44, p.2167-2171, 2006.

LAMOUR, N.; RIVIERE, L.; COUSTOU, V.; COOMBS, GH.; BARRETT, MP.; BRINGAUD, F. Proline metabolism in procyclic Trypanosoma brucei is downregulated in the presence of glucose. J. Biol. Chem., v.280, p.11902-10, 2005.

LANA, M.; CHIARI, C. Caracterizacão biológica comparativa das cepas Berenice-62 e Berenice-78 de Trypanosoma cruzi, isoladas da mesma paciente em diferentes períodos. Mem. Inst. Oswaldo Cruz, v.81, p.247-253, 1986.

LANA, M.; CHIARI, E.; TAFURI, W. Experimental Chagas' disease in dogs. Mem. Inst. Oswaldo Cruz, v.87, p.59-71, 1992.

LAZAROU, M.; MCKENZIE, M.; OHTAKE, A.; THORBURN, D.; RYAN, M. Analysis of the assembly profiles for mitochondrial and nuclear DNA encoded subunits into complex I. Mol. Cell. Biol., v.27, p.4228-4237, 2007.

LE TRANT, N.; MESHNICK, S.; KITCHENER, K.; EATON, J.; CERAMI, A. Ironcontaining superoxide dismutase from Crithidia fasciculata. Purification, characterization, and similarity to Leishmanial and trypanosomal enzymes. $\mathbf{J}$. Biol.Chem., v.258, p.125-130, 1983. 
LIU, Y.; FISKUM, G.; SCHUBERT, D. Generation of reactive oxygen species by the mitochondrial electron transport chain. J. Neurochem., v.80, p.780-787, 2002.

LOPEZ, J.; CARVALHO, T.; DE SOUZA, W.; FLOHE, L.; GUERRERO, S.; MONTEMARTINI, M.; KALISZ, H.; NOGOCEKE, E.; SINGH, M.; ALVES, M.; COLLI, W. Evidence for a trypanothione-dependent peroxidase system in Trypanosoma cruzi. Free Radic. Biol. Med., v. 28, p. 767-772, 2000.

LOSCHEN, G.; AZZI, A.; FLOHE, L. Superoxide radicals as precursors of mitochondrial hydrogen peroxide. FEBS Lett., v.42, p.68-72, 1974.

LUQUETTI, A.; MILES, M.; RASSI, A.; DE REZENDE, J.; DE SOUZA, A.; POVOA, M.; RODRIGUES, I. Trypanosoma cruzi: symodemes associated with acute and chronic Chagas disease in central Brazil. Trans. R. Soc. Trop. Med. Hyg., v.80, p.462-470, 1986.

MACEDO, A.; MACHADO, C.; OLIVEIRA, R.; PENA, S. Trypanosoma cruzi: genetic structure of populations and relevance of genetic variability to the pathogenesis of Chagas disease. Mem. Inst. Oswaldo Cruz, v.99, p.1-12, 2004.

MACEDO, A.; MARTINS, M.; CHIARI, E.; PENA, S. DNA finger-printing of Trypanosoma cruzi: a new tool for characterization of strains and clones. Mol. Biochem. Parasitol., v.55, p.147-154, 1992.

MACEDO, A.; PIMENTA, J.; AGUIAR, R.; MELO, A.; CHIARI, E.; ZINGALES, B.; PENA, S.; OLIVEIRA, R. Usefulness of microsatellite typing in population genetic studies of Trypanosoma cruzi . Mem. Inst. Oswaldo Cruz, v. 96, p.407-413, 2001. Review.

MACHADO, C.; AYALA, F. Nucleotide sequences provide evidence of genetic exchange among distantly related lineages of Trypanosoma cruzi. Proc. Natl. Acad. Sci., v.98, p.7396-7401, 2001.

MACHADO, F.; MARTINS, G.; ALIBERTI, J.; MESTRINER, F.; CUNHA, F.; SILVA, J. Trypanosoma cruzi-infected cardiomyocytes produce chemokines and cytokines that trigger potent nitric oxide-dependent trypanocidal activity. Circulation, v.102, p.3003-3008, 2000.

MAIR, G.; SHI, H. LI, H.; DJIKENG, A.; AVILES, H.; BISHOP, J.; FALCONE, F.; GAVRIELESCU, C.; MONTGOMERY, J.; SANTORI, I.; STERN, L.; WANG, Z.; 
ULLU, E.; TSCHUDI, C. A new twist in trypanosome RNA metabolism: cis-splicing of pre-RNA. RNA, v.6, p.163-169, 2000.

MALFATTI, E.; BUGIANI, M.; INVERNIZZI, F.; FISCHINGER, C.; FARINA, L.; CARRARA, F.; LAMANTEA, E.; ANTOZZI, C.; CONFALONIERI, P.; SANSEVERINO, M.; GIUGLIANI, R.; UZIEL, G.; ZEVIANI, M. Novel mutations of $N D$ in complex I defifiency associated with mitochondrial encephalopathy. Brain, v.130, p.1894-1904, 2007.

MARR, J.; BERENS R. Regulation of aerobic fermentation in protozoans. VI. Comparative biochemistry of pathogenic and nonpathogenic protozoans. Acta Trop., v.34, p.143-55, 1977.

MAUGERI, D.; CAZZULO, J. The pentose phosphate pathway in Trypanosoma cruzi. FEMS Microbiol., v.234, p117-123, 2004.

MAYEVSKY, A.; ROGATSKY, G. Mitochondrial function in vivo evaluated by NADH fluorescence: from animal models to human studies. Am. J. Physiol. Cell. Physiol., v.292, p.615-640, 2007.

MENDONÇA, M.; NEHME, N.; SANTOS, S.; CUPOLILLO, E.; VARGAS, N.; JUNQUEIRA, A.; NAIFF, R.; BARRETT, T.; COURA, J.; ZINGALES, B.; FERNANDES, O. Two main clusters within Trypanosoma cruzi zymodeme 3 are defined by distinct regions of the ribosomal RNA cistron. Parasitology, v.124, p.177184, 2002.

MESHNIK, S.; BLOBSTEIN, S.; GRADY, R.; CERAMI, A. Na approach to the development of new drugs for African trypanosomiasis. J. Exp. Med., v.148,p. 569579, 1978.

MICHELS, P.; BRINGAUD, F.; HERMAN, M.; HANNAERT, V. Metabolic functions of glycosomes in trypanosomatids. Biochim. Biophys. Acta, v.1763, p.1463-1477, 2006. Review.

MIELNICZKI-PEREIRA, A.; CHIAVEGATTO, C.; LÓPEZ, J.; COLLI, W.; ALVES, M.; GADELHA, F. Trypanosoma cruzi strains, Tulahuen 2 and $Y$, besides the difference in resistance to oxidative stress, display differential glucose-6-phosphate and 6phosphogluconate dehydrogenases activities. Acta Trop., v.101, p. 54-60, 2007. 
MILES, M.; SOUZA, A.; POVOA, M.; SHAW, J.; LAINSON, R. TOYE, J. Isozymic heterogeneity of Trypanosoma cruzi in the first auctochthonous patients with Chagas disease in Amazonian Brazil. Nature, v.272, p.819-821, 1978.

MILETTI, L.; KOERICH, L.; PACHECO, L.; STEINDEL, M.; STAMBUK, M. Characterization of D-glucose transport in Trypanosoma rangeli. Parasitology, v.133, p.721-727, 2006.

MILLER, A. Superoxide dismutases: active sites that save, but a protein that kills. Curr. Opin. Chem. Biol., v.8, p.1-7, 2004.

MINNING, T.; BUA, J.; GARCIA, G.; MCGAW, R.; TARLETON, R.; Microarray profiling of gene expression during trypomastigote to amastigote transition in Trypanosoma cruzi. Mol. Biochem. Parasitol., v.131, p.55-64, 2003.

MOHANTY, J.; JAFFE, J.; SCHULMAN, E.; RAIBLE, D. A highly sensitive fluorescent micro-assay of $\mathrm{H}_{2} \mathrm{O}_{2}$ release from activated human leukocytes using a dihydroxyphenoxazine derívate. J. Immunol. Methods, v.202, p.133-141, 1997.

MONCAYO, A.; ORTIZ, Y. An update on Chagas disease (human American trypanosomiasis). Ann. Trop. Med. Parasitol., v.100, p.663-677, 2006.

MONTAMAT, E.; DE LUCA D`ORO, G, GALLERANO, R.; SOSA, R.; BLANCO, A. Characterization of Trypanosoma cruzi populations by zymodemes: correlation with clinical picture. Am. J. Trop. Med. Hyg., v.55. p.625-628, 1996.

MONTEMARTINI, M.; BÚA, J.; BONTEMPI, E.; ZELADA, C.; RUIZ, A.; SANTOMÉ, J.; CAZZULO, J.; NOWICKI, C. Recombinant tyrosine aminotransferase from Trypanosoma cruzi has both tyrosine aminotransferase and alanine aminotransferase activities. FEMS Microbiol. Lett., v.33, p.17-20, 1995.

MOREL, C.; CHIARI, E.; CAMARGO, E.; MATTEI, D.; ROMANHA, A.; SIMPSON L. Strains and clones of Trypanosoma cruzi can be characterized by pattern of restriction endonuclease products of kinetoplast DNA minicircles. Proc. Natl. Acad. Sci. USA, v.77, p.6810-6814, 1980.

NAKAE, Y.; SHONO, M. Histochemical modification of the active site of succinate dehydrogenase with $\mathrm{N}$-acetylimidazole. Histochem. J., v.18, v.169-74, 1986. 
NGO, H.; TSCHUDI, C.; GULL, K.; ULLU, E. Double-stranded RNA induces mRNA degradation in Trypanosoma brucei. Proc. Natl. Acad. Sci. USA, v.95, p.1468714692, 1998.

NICHOLAS, K.; NICHOLAS, H.; Deerfield, D. GeneDoc: Analysis and Visualization of Genetic Variation. EMBNEW. NEWS, v. 4, p.14, 1997.

NOGOCEKE, E.; GOMMEL, D.; KIESS, M.; KALISZ, H.; FLOHE, L. A unique cascade of oxidoreductases catalyses trypanothione mediated peroxide metabolism in Crithidia fasciculate. Biol. Chem., v.378, p.827- 836, 1997.

NOGUEIRA, F.; KRIEGER, M.; NIRDÉ, P.; GOLDENBERG, S.; ROMANHA, A.; MURTA, S. Increased expression of iron-containing superoxide dismutase-A (TcFeSOD-A) enzyme in Trypanosoma cruzi population with in vitro-induced resistance to benznidazole. Acta Trop., v.100, p.119-132, 2006.

NOZAKI, T.; SHIGETA, Y.; SAITO-NAKANO, Y.; IMADA, M.; KRUGER, W. Characterization of transsulfuration and cysteine biosynthetic pathways in the protozoan hemoflagellate, Trypanosoma cruzi. Isolation and molecular characterization of cystathionine beta-synthase and serine acetyltransferase from Trypanosoma. J. Biol. Chem., v.276, p.6516-23, 2001.

OCHS, D.; OTSU, K.; TEIXEIRA, S.; MOSER, D.; KIRCHHOFF, L.; Maxicircle genomic organization and editing of an ATPase subunit 6 RNA in Trypanosoma cruzi. Mol. Biochem. Parasitol., v.76, p.267-278, 1996.

OPPERDOES, F.; MICHELS, P. Complex I of Trypanosomatidae: does it exist?. Trends Parasitol., v.24, p.310-317, 2008.

ORGANIZAÇÃO PAN AMERICANA DA SAUDE. Estimación cuantitativa de la enfermedad de Chagas en las Américas. Montevideo, Uruguay: OPS, 2006.

OZA, S.; SHAW, M.; WYLLIE, S.; FAIRLAMB, A. Trypanothione biosynthesis in Leishmania major. Mol. Biochem. Parasitol., v.139, p.107-116, 2005.

PAN AMERICAN HEALTH ORGANIZATION. National Blood Systems in the Caribbean and Latin American countries: Basic indicators of their status in 2004. Local: Washington, D.C. USA: PAHO, 2006. 
PAULIN, J. The chondriome of selected trypanosomatidia. Three-dimensional study based on serial thick sections and high voltage electron microscopy. J. Cell. Biol., v.66, p.404-413, 1975.

PEACOCK, C.; SEEGER, K.; DAVID, HARRIS, D.; et al. Comparative genomic analysis of three Leishmania species that cause diverse human disease. Nat. Genet., v.39.; p.839-847, 2007.

PENKETH, G.; KLEIN, R. Hydrogen peroxide metabolism in Trypanosoma brucei. Mol. Biochem. Parasitol., v.20, p.111-121, 1986.

PEREIRA, C.; ALONSO, G.; PAVETO, M.; IRIBARREN, A.; CABANAS, M.; TORRES, H.; FLAWIA, M. Trypanosoma cruzi arginine kinase characterization and cloning. A novel pathway in protozoan parasites. J. Biol. Chem., v.275, p.1495$1501,2000$.

PETERSON, G.; SOUZA, A.; PARSONS, M. Characterization of a Trypanosoma brucei nuclear gene encoding a protein homologous to a subunit of bovine NADH:ubiquinone oxidoreductase (complex I). Mol. Biochem. Parasitol., v.58, p.63-70, 1993.

PFAFFL, M. A new mathematical model for relative quantification in real-time RTPCR. Nucleic Acids Res., v.29, p. 2002-2007, 2001.

PHILIPS, H. Dye exclusions tests for cell viability. In: KRUSE, J.; PATTERSON, J. (Ed.). Tissue culture, methods and applications. New York: Academic Press, 1973, p. 406-408.

PIACENZA, L.; IRIGOIN, F.; ALVAREZ, M.; PELUFFO, G.; TAYLOR, M.; KELLY, J.; WILKINSON, S.; RADI, R. Mitochondrial superoxide radicals mediate programmed cell death in Trypanosoma cruzi: cytoprotective action of mitochondrial iron superoxide dismutase overexpression. Biochem. J., v.403, p.323-334, 2007.

PINEAU, B.; MATHIEU, CH.; GÉRARD-HIRNE, C.; DE PAEPE, R.; CHÉTRIT , P. Targeting the NAD7 Subunit to Mitochondria Restores a Functional Complex I and a Wild Type Phenotype in the Nicotiana sylvestris CMS II Mutant Lacking nad7. J. Biol Chem., v.280, p.25994-26001, 2005.

PIÑEYRO, M.; PIZARRO, J.; LEMA, F.; PRITSCH, O.; CAYOTA, A.; BENTLEY, G.; ROBELLO, C. Crystal structure of the tryparedoxin peroxidase from the human parasite Trypanosoma cruzi. J. Struct. Biol., v.150, p.11-22, 2005. 
PINTO DIAS, J. The treatment of Chagas disease (South American trypanosomiasis). Ann. Intern. Med., v.144, p.772-774, 2006.

PRATA, A. Clinical and epidemiological aspects of Chagas disease. Lancet Infect. Dis., v.1, p.92-100, 2001.

RAMASAWMY, R.; CUNHA-NETO, E.; FAÉ, K.; MARTELLO, F.; MULLER, N.; CAVALCANTI, V.; LANNI, B.; MADY, C.; KALIL, J.; GOLDBERG, A. The Monocyte Chemoattractant Protein-1 Gene Polymorphism Is Associated with Cardiomyopathy in Human Chagas Disease. Clin. Infect. Dis., v.43, p.305-311, 2006.

RASSI, A Jr.; RASSI, A.; LITTLE, W.; XAVIER, S.; RASSI, S.; RASSI, A.; RASSI, G.; HASSLOCHER-MORENO, A.; SOUSA, A.; SCANAVACCA, M. Development and validation of a risk score for predicting death in Chagas heart disease. N. Engl. $\mathbf{J}$ Med., v.355, p. 799-808, 2006.

RASSI, A Jr.; RASSI, A.; RASSI, S. Predictors of mortality in chronic Chagas disease: a systematic review of observational studies. Circulation, v.115, p.11011108, 2007. Review.

REINA-SAN MARTÍN, A.; COSSON, A.; MINOPRIO, P. Lymphocyte polyclonal activation: a pitfall for vaccine design against infectious agents. Parasitol. Today, v.16, p. 62-67, 2000.

REIS, D.; JONES, E.; TOSTES, S.; LOPES, E.; CHAPADEIRO, E.; GAZZINELLI, G.; COLLEY, D.; MCCURLEY, T. Characterization of inflammatory infiltrates in chronic chagasic myocardial lesions: presence of tumor necrosis factor-alpha+ cells and dominance of granzyme A+, CD8+ lymphocytes. Am. J. Trop. Med. Hyg., v.48, p.637-44, 1993.

REIS, M.; HIGUCHI, M.; BENVENUTI, L.; AIELLO, V.; GUTIERREZ, P.; BELLOTTI, G.; PILEGGI, F. An in situ quantitative immunohistochemical study of cytokines and IL-2R+ in chronic human chagasic myocarditis: correlation with the presence of myocardial Trypanosoma cruzi antigens. Clin. Immunol. Immunopathol., v.83, p.165-172, 1997.

ROCHA, M.; RIBEIRO, A.; TEIXEIRA, M. Clinical management of chronic Chagas cardiomyopathy. Front. Biosci., v.8, p44-54, 2003.

RODRIGUES, C.; CATISTI, R.; UYEMURA, S.; VERCESI, A.; LIRA, R.; RODRIGUEZ, C.; URBINA, J.; DOCAMPO, R. The sterol composition of 
Trypanosoma cruzi changes after growth in different culture media and results in different sensitivity to digitonina-permeabilization. J. Eukariot. Microbiol., v.48, p.588-594, 2001.

ROVIN, B.; LU, L.; SAXENA, R. A novel polymorphism in the MCP-1 gene regulatory region that influences MCP-1 expression. Biochem. Biophys. Res. Commun., v.259, p.344-8, 1999.

SANTOS, S.; CUPOLILLO, E.; JUNQUEIRA, A.; COURA, J.; JANSEN, A.; STURM, N, CAMPBELL, D.; FERNADES, O. The genetic diversity of Brazilian Trypanosoma cruzi isolates and the phylogenetic positioning of symodeme 3 , based on the internal transcribed spacer of the ribosomal gene. Ann. Trop. Med. Parasitol., v.96, p.755764, 2002.

SAZANOV, L.; HINCHLIFFE, P. Structure of the hydrophilic domain of respiratory complex I from Thermus thermophilus. Science, v.311, p.14301436, 2006.

SCHMUNIS, G. Epidemiology of Chagas disease in non endemic countries: the role of international migration. Mem. Inst. Oswaldo Cruz, p.11, 2007.

SCHMUNIS, G. The globalization of Chagas disease. Journal compilation 2007 Blackwell Publishing Ltd. ISBT. Science. Ser., v.2, p.6-11, 2007.

SEO, B.; KITAJIMA-IHARA, T.; CHAN, E.; SCHEFfIER, I.; MATSUNO-YAGI, A.; YAGI, T. Molecular remedy of complex I defects: Rotenone-insensitive internal $\mathrm{NADH}$-quinone oxidoreductase of Saccharomyces cerevisiae mitochondria restores the NADH oxidase activity of complex I-deficient mammalian cells. Proc. Natl. Acad. Sci. USA, v.95, p. 9167-9171, 1998.

SHAMES, S.; FAIRLAMB, A.; CERAMI, A.; WALSH, C. Trypanothione reductase of Trypanosoma congolense: gene isolation, primary sequence determination, and comparison to glutathione reductase. Biochemistry, v.25, p.3519-3526, 1986.

SHLOMAI, J. The structure and replication of kinetoplasto DNA. Curr. Mol. Med., v.4, p.623-647, 2004. Review.

SILBER, A.; COLLI, W.; ULRICH, H.; ALVES, M.; PEREIRA, C. Amino Acid Metabolic Routes in Trypanosoma cruzi: Possible Therapeutic Targets Against Chagas' Disease. Curr. Drug Targets Infect. Disord., v.5, p.53-64, 2005. 
SLOOF, P.; ARTS, G.; VAN DEN BURG, J.; VAN DER SPEK, H.; BENNE R. RNA editing in mitochondria of cultured trypanosomatids: translatable mRNAs for NADHdehydrogenase subunits are missing. J. Bioenerg. Biomembr., v.26, p.193-203, 1994.

SOARES, M.; SOUTO-PADRON, T.; DE SOUZA, W. Identification of a large prelysosomal compartment in the pathogenic protozoon Trypanosoma cruzi. J. Cell. Sci., v.102., p.157-167, 1992.

SOUTO, R.; FERNADES, O.; MACEDO, A.; CAMPBELL, D.; ZINGALES, B. DNA markers define two major phylogenetic lineages of Trypanosoma cruzi. Mol. Biochem. Parasitol., v.83, p.141-152, 1996.

SPEIJER, D.; BREEK, C.; MUIJSERS, A.; HARTOG, A.; BERDEN, J.; ALBRACHT, S.; SAMYN, B.; VAN BEEUMEN, J.; BENNE, R. Characterization of the respiratory chain from cultured Crithidia fasciculata. Mol. Biochem. Parasitol., v.85, p.171-186, 1997.

STOPPANI, A.; DOCAMPO, R.; BOISO, J.; FRASCH, A. Effect of inhibitors of electron transport and oxidative phosphorylation on Trypanosoma cruzi and growth. Mol. Biochem. Parasitol., v.2, p.3-21, 1980.

SYLVESTER, D.; KRASSNER, S. Proline metabolism in Trypanosoma cruzi epimastigotas. Comp. Biochem. Physiol. B., v.55, p.443-7, 1976.

TARLETON, R. Parasite persistence in the aetiology of Chagas disease. Int. J. Parasitol., v.31, p.550-554, 2001.

TARLETON, R.; REITHINGER, R.; URBINA, J.; KITRON, U.; GÜRTLER, R. The Challenges of Chagas Disease-Grim Outlook or Glimmer of Hope?. PLoS Med., v.4, p.1852-1857, 2007.

TEIXEIRA, M.; DASILVA, M.; MARCILI, A.; UMEZAWA, E.; SHIKANAI-YASUDA, M.; CUNHA-NETO, E.; KALIL, J.; STOLF, N.; STOLF, A. Trypanosoma cruzi lineage I in endomyocardial biopsy from a north-eastern Brazilian patient at end-stage chronic chagasic cardiomyopathy. Trop. Med. Int. Health, v.11. p.294-298, 2006.

TEIXEIRA, M.; GAZZINELLI, R.; SILVA, J. Chemokines, inflammation and Trypanosoma cruzi infection. Trends Parasitol., v.18, p.262-265, 2002. 
TEIXEIRA, S.; Da ROCHA, W. Control of gene expression and genetic manipulation in the Trypanosomatidae. Genet. Mol. Res., v.2, p.148-158, 2003. Review.

TEMPERTON, N.; WILKINSON, S.; KELLY, J. Cloning of an Fe-superoxide dismutase gene homologue from Trypanosoma cruzi. Mol. Biochem. Parasitol., v.76, p.339-43, 1996.

TIBAYRENC, M.; AYALA, F. Isoenzyme variability in Tryoanosma cruzi, the agent of Chagas disease: genetical, taxonomic and epidemiological significance. Evolution, v.42, p.277-292, 1988.

TIBAYRENC, M.; WARD, P.; MOYA, A.; AYALA, F. Natural populations of Trypanosoma cruzi, the agent of Chagas disease, have a complex multiclonal structure. Proc. Natl. Acad. Sci. USA, v.83, p.115-119, 1986.

TIELENS, A.; VAN HELLEMOND, J. Differences in energy metabolism between trypanosomatidae. Parasitol. Today, v.14, p265-271, 1998.

TONELLI, R.; SILBER, A.; MARTINEZ, I.; HIRATA, I.; COLLI, W.; ALVES M. LProline is essential for the intracellular differentiation of Trypanosoma cruzi. Cell. Microbiol., v.6, p.733-741, 2004.

TRUJILLO, M.; BUDDE, H.; PINEYRO, M.; STEHR, M.; ROBELLO, C.; FLOHE, L.; RADI, R. Trypanosoma brucei and Trypanosoma cruzi Tryparedoxin Peroxidases Catalytically Detoxify Peroxynitrite via Oxidation of Fast Reacting Thiols. J. Biol. Chem., v.279, p.34175-34182, 2004.

TURRENS, J. Mitochondrial formation of reactive oxygen species. J. Physiol., v.552, p.335-344, 2003.

TURRENS, J. Oxidative stress and antioxidant defenses: a target for the treatment of diseases caused by parasitic protozoa. Mol. Aspects Med., v.25, p.211-220, 2004.

TURRENS, J. The role of succinate in the respiratory chain of Trypanosoma bruceiprocyclic trypomastigotes. Biochem. J., v.259, p.363-368, 1989. Review.

TURRENS, J.; RUBBO, H.; DENICOLA-SEOANE, A.; MORENO, S.; DOCAMPO, R. Fumarate reductase activity in Trypanosoma cruzi epimastigotas and amastigotas and Leishmania donovani promastigotes. Am. J. Trop. Med. Hyg., v.47, p.75, 1992. 
TURRENS, J.; BOVERIS, A. Generation of superoxide anion by the NADH dehydrogenase of bovine heart mitochondria. Biochem. J., v.191, p.421-427, 1980.

ULLU, E.; TSCHUDI, C.; CHAKRABORTY, T. RNA interference in protozoan parasites. Cell. Microbiol., v.6, p.509-519, 2004.

URBINA, J. Intermediary metabolism of Trypanosoma cruzi. Parasitol. Today, v.10, p. 107-109, 1994. Review.

VAGO, A.; ANDRADE, L.; LEITE, A.; D`AVILA REIS, D.; MACEDO, A.; ADAD, S.; TOSTES, S.; MOREIRA, C.; FILHO, G.; PENA, S. Genetics characterization of Trypanosoma cruzi directly from tissues of patients with chronic Chagas disease: differential distribution of genetic types into diverse organs. Am. J. Pathol., v.156, p.1805-1809, 2000.

VAGO, A.; MACEDO, A.; ADAD, S.; REIS, D.; CORREA-OLIVEIRA, R. PCR detection of Trypanosoma cruzi DNA in oesophageal tissues of patients with chronic digestive Chagas disease. Lancet, v.348, p.891-892, 1996.

VAGO, A.; MACEDO, A.; OLIVEIRA, R.; ANDRADE, L.; CHIARI, E.; GALVAO, L.; REIS, D.; PEREIRA, M.; SIMPSON, A.; TOSTES, S.; PENA S. Kinetoplast DNA signatures of Trypanosoma cruzi strains obtained dierctly from infected tissues. Am. J. Pathol., v.149, p.2153-2159, 1996.

VERCESI, A.; BERNARDES, C.; HOFFMAN, M.; GADELHA, F.; DOCAMPO, R. Digitonin permeabilization does not affect mitochondrial function and allows the determination of the mitochondrial membrane potencial of Trypanosoma cruzi in situ. J. Biol. Chem., v.266, p.14431 - 14434, 1991.

VIDEIRA, A.; DUARTE, M. From NADH to ubiquinone in Neurospora mitochondria, Biochim. Biophys. Acta, v.1555, p. 187-191, 2002.

VOET, D.; VOET, J. Bioquímica. 3. ed. Porto Alegre: Artmed, 2006. 808 p.

WANG, Z.; MORRIS, J.; DREW, M.; ENGLUND, P. Inhibition of Trypanosoma brucei gene expression by RNA interference using an integratable vector with opposing T7 promoters. J. Biol. Chem., v.275, p.40174-40179, 2000. 
WESTENBERGER, S.; BARNABE, C.; CAMPBELL, D.; STURM, N. Two hybridization events define the population structure of Trypanosoma cruzi. Genetics, v.171, p.527-543, 2005. Review.

WESTENBERGER, S.; CERQUEIRA, G.; EL-SAYED, N.; ZINGALES, B.; CAMPBELL, D.; STURM, N. Mitochondrial maxicircles display conservation of gene order and a conserved element in the non-coding region in Trypanosoma cruzi. BMC Genomics, v.7, p.1-18, 2006.

WORLD HEALTH ORGANIZATION, Technical Report Series, Control of Chagas disease. Geneva: W.H.O. 2002.

WILKINSON, S.; TEMPERTON, N.; MONDRAGON, A.; KELLY, J. Distinct Mitochondrial and Cytosolic Enzymes Mediate Trypanothione-dependent Peroxide Metabolism in Trypanosoma cruzi. J. Biol. Chem., V.275, p.8220-8225, 2000a.

WILKINSON, S.; MEYER, D.; TAYLOR, M.; BROMLEY, E.; MILES, M.; KELLY, J. The Trypanosoma cruzi enzyme TcGPXI is a glycosomal peroxidase and can be linked to trypanothione reduction by glutathione or tryparedoxin. J. Biol. Chem., v.277, p.17062-17071, 2002a.

WILKINSON, S.; OBADO, S.; MAURICIO, I.; KELLY, J. Trypanosoma cruzi expresses a plant-like ascorbate-dependent hemoperoxidase localized to the endoplasmic reticulum. Proc. Natl. Acad. Sci. USA, v.99, p.13453-13458, 2002b.

WILKINSON, S.; PRATHALINGAM, R.; TAYLOR, M.; AHMED, A.; HORN, D.; KELLY $J$. Functional characterisation of the iron superoxide dismutase gene repertoire in Trypanosoma brucei. Free Radic. Biol. Med., v.40, p.198 - 209, 2006.

WORLD BANK. Global burden of disease and risk factors. In: LOPEZ, A.; MATHERS, D.; EZZATI, C.; JAMISON, D.; MURRAY, C. Global and regional burden of disease and risk factors: systematic analysis of population health data. Geneva: Oxford University Press, 2006. 228 p.

YAGI, T.; MATSUNO-YAGI, A. The Proton-Translocating NADH-Quinone Oxidoreductase in the Respiratory Chain: The Secret Unlocked. Biochemistry, v.42, p.2266-2274, 2003.

YAGI, T.; YANO, T.; DI BERNARDO, S.; MATSUNO, A. Prokaryotic complex I (NDHI), an overview. Biochim. Biophys. Acta, v.1363, p.125-133, 1998. 
YAMATO, K.; NEWTON, K. Heteroplasmy and homoplasmy for maize mitochondrial mutants: A rare homplasmic nad4 deletion mutant plant. J. Hered., v.90, p.369-373, 1999.

YOSHIBA, Y.; KIYOSUE, T.; NAKASHIMA, K.; YAMAGUCHI-SHINOZAKI, K.; SHINOZAKI, K. Regulation of levels of proline as an osmolyte in plants under water stress. Plant. Cell. Physiol., v.38, p.1095-1102, 1997.

ZACKS, M.; WEN, J.; VYATKINA, G.; BHATIA, V.; GARG, N. An overview of chagasic cardiomiopathy: pathogenic importance of oxidative stress. An. Acad. Bras. Cienc., v.77, p.695-715, 2005.

ZHOU, M.; DIWU, Z.; PANCHUK-VOLOSHINA, N.; HAUGLAND, R. A stable nonfluorescent derivative of resorufin for the fluorometric determination of trace hydrogen peroxide: applications in detecting the activity of phagocyte NADPH oxidase and other oxidases. Anal. Biochem., v.253, p.162-168, 1997.

ZICKER, F.; NETTO, JC.; ZICKER, E.; OLIVEIRA, R.; SMITH, P. Trypanosoma cruzi infection and electrocardiographic findings among active manual workers. A population-based study in central Brazil. Int. J. Epidemiol., v.19, p.182-186, 1990.

ZINGALES, B.; SOUTO, R.; MANGIA, R.; LISBOA, C.; CAMPBELL, D.; COURA, J.; JANSEN, A.; FERNADES, O. Molecular epidemiology of American Trypanosomiasis in Brazil base on dimorphisms of rRNA and mini-exon gene sequences. Int. J. Parasitol., v.28, p.105-112, 1998. 


\section{ANEXOS}

\section{ANEXO A ARTIGO EM PREPARAÇÃO.}

CARRANZA, M.; D'ÁVILA, D.; VALADARES, H.; BAPTISTA, R.; GALVÃO, L.; CHIARI, E.; STURM, N.; GONTIJO, E.; MACEDO, A.; ZINGALES, B. Maxicircle genetic characterization of Trypanosoma cruzi isolates from patients with the indeterminate and cardiac forms of Chagas disease, 2008. (em fase de elaboração).

\section{ANEXO B ARTIGO PUBLICADO.}

BAPTISTA, C.; VENCIO, R.; ABDALA, S.; CARRANZA, J.; WESTERBERGER, S.; SILVA, M.; DE B PEREIRA, C.; GALVÃO, L.; GONTIJO, E.; CHIARI, E.; STURM, N.; ZINGALES, B. Differential transcription profiles in Trypanosoma cruzi associated with clinical forms of Chagas disease: Maxicircle NADH dehydrogenase subunit 7 gene truncation in asyntomatic patient isolates. Mol. Biochem. Parasitol., v.150, p.236248, 2006. 